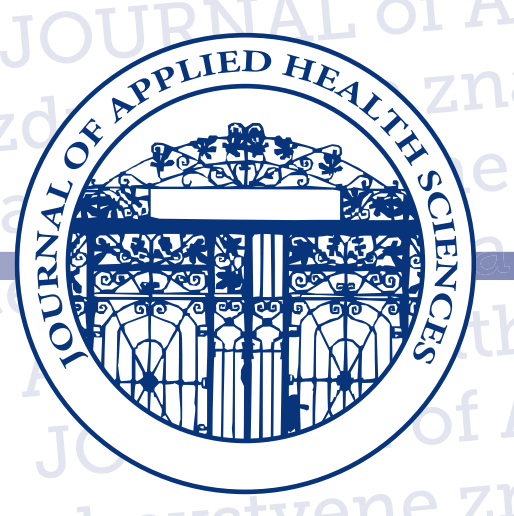

\title{
Journal of Applied
} Health Sciences

\section{Časopis za primijenjene zdravstvene znanosti}




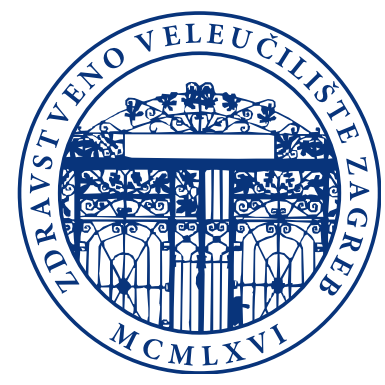

\section{Zdravstveno veleučilište u Zagrebu}

\section{Journal of Applied Health Sciences \\ Časopis za primijenjene zdravstvene znanosti}

ISSN

1849-8361

UDK

61

GODINA IZDAVANJA

2015.

VOLUMEN - GODIŠTE IZLAŽENJA

1

BROJ TEKUĆEG SVEŠČIĆA

1.

STRANICE SVEŠČIĆA OD-DO:

1-76

MJESTO IZDAVANJA

Zagreb

NAZIV IZDAVAČA I NAKLADNIKA

Zdravstveno veleučilište

UČESTALOST IZLAŽENJA

Časopis izlazi dva puta godišnje 
NAKLADNIK

ZDRAVSTVENO VELEUČILIŠTE

Mlinarska cesta 38

ZA IZDAVAČA

Dr. sc. Aleksandar Racz, prof. v.š.

LEKTURA

Tekstura, Obrt za lekturu i usluge u izdavaštvu

GRAFIČKO OBLIKOVANJE I TISAK

OFFSET TISAK NP GTO

NAKLADA

2000 kom.

Copyright (c) 2015. Zdravstveno veleučilište Zagreb 
JOURNAL OF APPLIED HEALTH SCIENCES / ČASOPIS ZA PRIMIJENJENE ZDRAVSTVENE ZNANOSTI

\section{Sadržaj / Contents}

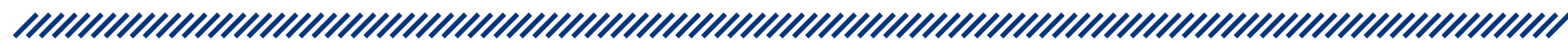

\section{LANA MUŽINIĆ}

Uvodna riječ glavne urednice

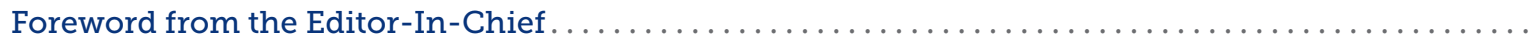

ALEKSANDAR RACZ

Uvodna riječ dekana Zdravstvenog veleučilišta Zagreb

Foreword from the Dean of the University of Applied Health Sciences. . . . . . . . . . . . . . . . . . . .

\section{Izvorni znanstveni rad / Original scientific paper}

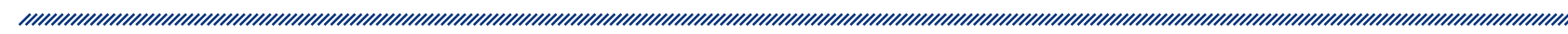

JANKO BABIĆ, MELITA RUKAVINA, MORANA BILIĆ

Je li tjelesna aktivnost studenata Zdravstvenog veleučilišta povezana s njihovim osobinama ličnosti?

Is physical activity of the students at the University of Applied Health Sciences

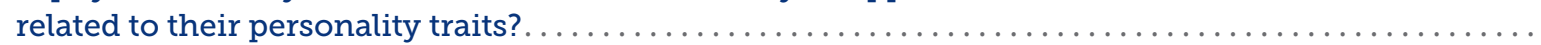

\section{Pregledni rad / Review}

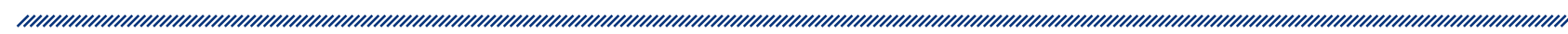

SLAĐANA ŠTRKALJ IVEZIĆ, LANA MUŽINIĆ, MARIJO VRDOLJAK

Psihoedukacija o antipsihoticima u povećanju suradljivosti i efikasnosti liječenja

Psychoeducation about antipsychotics as a way of increasing adherence and treatment efficacy .........

\section{Prethodna priopćenja / Preliminary communication}

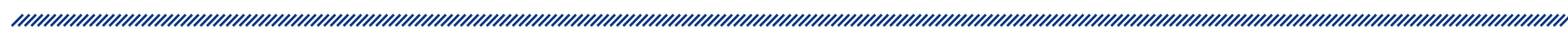

SNJEŽANA ČUKLJEK, MARTINA SMREKAR, SANJA LEDINSKI FIČKO, VESNA KONJEVODA

Razlike u percepciji sestrinstva između studenata sestrinstva i zaposlenih medicinskih sestara

Differences in the perception of the nursing profession between nursing students and employed nurses

JOSIPA ROŽMAN, GORAN ARBANAS

Stigmatiziraju li studenti i studentice sestrinstva oboljele od posttraumatskog stresnog poremećaja?

Do nursing students stigmatize patients suffering from posttraumatic stress disorder? ...........

\section{Stručni radovi / Professional papers}

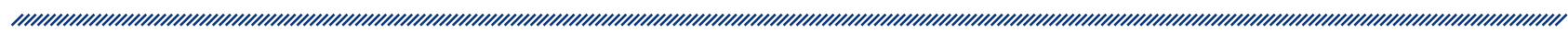

HRVOJE GUDLIN

Ewingov sarkom i fizioterapija kao dio medicinskog tretmana u rehabilitaciji onkoloških bolesnika

Ewing's sarcoma and physiotherapy as a part of medical treatment in the rehabilitation of oncological patients 51-56

ZLATA PJEVIĆ, SLAĐANA ŠTRKALJ IVEZIĆ, ANJA MELADA

Stilovi sučeljavanja sa stresom $u$ odnosu na različite dijagnoze psihičkih poremećaja

Stress coping styles in relation to various psychiatric disorders. 



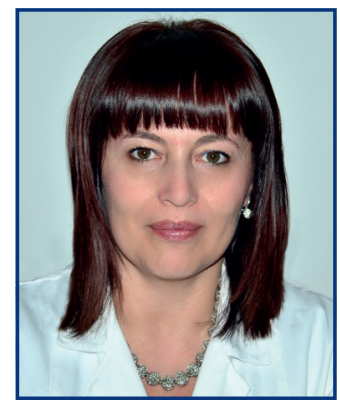

\section{Uvodna riječ glavne urednice}

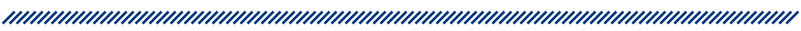

Posebna mi je čast predstaviti prvi broj Časopisa za primijenjene zdravstvene znanosti - časopisa čijim pokretanjem potičemo objavljivanje i razmjenu znanja stručnjaka na području zdravstva. Časopisom ćemo, objavljivanjem radova utemeljenih na znanstvenim istraživanjima i iskustvima iz kliničke prakse, nastojati pridonijeti znanstvenom i stručnom radu te razvoju svih profila koji se educiraju na Zdravstvenom veleučilištu.

Časopis je otvoren i za sve druge stručnjake iz područja zdravstva. Njegova se interdisciplinarnost ogleda u sastavu uredništva, savjeta i recenzenata - uvaženih domaćih i stranih znanstvenika i stručnjaka iz raznih područja zdravstva. Uredništvo će objavljivanjem kvalitetnih radova nastojati pružiti vrijedne informacije zdravstvenim profesionalcima, ali i omogućiti prepoznatljivost časopisa u stručnim krugovima, kao i indeksaciju časopisa u međunarodnim bazama znanstvenih informacija.

Pokretanje časopisa jedinstveni je odraz želja i podrške svih subjekata Zdravstvenog veleučilišta u Zagrebu nastavnika, Upravnog vijeća, Stručnog vijeća, Studentskog zbora i prije svih dekana, što je temelj i svojevrsna garancija budućnosti časopisa. Prema entuzijazmu i odazivu stručnjaka koji su poslali radove za objavljivanje, vjerujemo u dobru budućnost i kontinuiranost izlaženja časopisa. Očekujemo da će radovi objavljeni u časopisu biti podrška kako u obrazovnom procesu tako i praćenju istraživačkih i stručnih dostignuća iz područja zdravstvenih znanosti. Zahvala članovima uredništva i recenzentima, kao i svima drugima koji su svojim predanim, aktivnim i entuzijastičnim radom pridonijeli nastanku i početku rada ovog časopisa, a posebno autorima koji su svojim radovima iskazali priznanje i povjerenje časopisu te time omogućili njegov nastanak i razvoj.

Glavna urednica

Izv. prof. dr. sc. Lana Mužinić

\section{Foreword from the Editor-in-Chief}

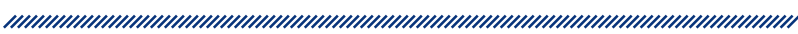

It is a special honor to present the first issue of the Journal of Applied Health Sciences - a journal whose launch encourages the publication and exchange of expert knowledge in the field of health. The journal will seek to contribute to scientific and professional work and to the development of all the professions educated at the University of Applied Health Sciences by publishing papers based on scientific research and clinical experience. The journal is open to all other experts in the field of health. Its interdisciplinary approach is reflected in the composition of the Editorial and Advisory Board and the reviewers - all renowned national and foreign scientists and experts in various fields of health sciences. The Editorial Board will endeavour to publish quality papers which will not only provide valuable information to health professionals, but also enable the recognition of the journal in professional circles as well as indexing of the journal in international scientific databases.

The launch of the journal is a unique reflection of the wishes and support of all the employees and bodies of the University of Applied Health Sciences in Zagreb - the teachers, the Governing Council, the Expert Council, the Student Union and first and foremost the Dean, which is the foundation and a guarantee of the journal's future. The enthusiasm and response from experts who have submitted their papers for publication has made us believe in its good prospects and continuity. We expect the published papers to provide support in the educational process and in keeping up with research and professional achievements in the field of health sciences. We thank the members of the Editorial Board, the reviewers, as well as all others whose dedicated, active and enthusiastic work contributed to the creation of this journal. We would like to give special thanks to the authors who have, by submitting their papers, expressed their recognition and trust in the journal and thus enabled its creation and development.

Editor-in-chief Lana Mužinić, PhD, associate professor 



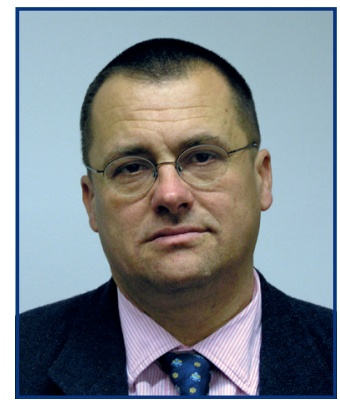

\section{Uvodna riječ dekana Zdravstvenog veleučilišta Zagreb}

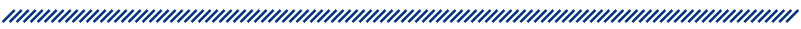

Zdravstveno veleučilište nedvojbeno je već desetljećima nezaobilazno mjesto stručnog i profesionalnog obrazovanja i razvoja različitih profila svih zdravstvenih radnika. Ponosni smo što od uvođenja državne mature interes srednjoškolaca za nastavak studija na jednom od šest studija pri Zdravstvenom veleučilištu snažno raste. Studij fizioterapije 2015. godine bio je najtraženiji studij s najvećim brojem prijava kao studij „, prvog izbora“, a studij radiološke tehnologije također rangiran među deset najtraženijih i svakako za maturante najizazovnijih studija. Zasluga je to velikih dugogodišnjih napora svih nastavnika, studenata i zaposlenika, sadašnjih i bivših, koji su svoj rad i znanje, kao i značajan dio svojeg života ugradili u temelje ove ustanove.

Bez lažne skromnosti smatramo da smo s punim pravom 2013. zaslužili ocjenu nadležnog ministra iskazanu u pisanom dokumentu kojom je jasno istaknuo: „U gotovo pola stoljeća razvoja Zdravstveno veleučilište izraslo je danas u vodeću ustanovu u visokom obrazovanju zdravstvenih radnika."

Zdravstveno veleučilište pravni je slijednik Visoke zdravstvene škole, koja je pak nastala na temeljima Više škola za medicinske sestre i zdravstvene tehničare osnovane u Zagrebu 1966. godine. U uvjetima izražene potrebe za višom razinom obrazovanja dotadašnjih srednjoškolskih profila zdravstvenih djelatnika Viša škola bila je jedina visokoškolska ustanova u Hrvatskoj koja je provodila obrazovanje bolničkih i dispanzersko-patronažnih medicinskih sestara, kao i radioloških, sanitarnih i laboratorijskih tehničara, na razini tadašnje više stručne spreme.

$\mathrm{Na}$ temeljima pedesetogodišnje povijesti, osnivač Ministarstvo znanosti, obrazovanja i sporta smatra da „strateško određenje i razvoj Veleučilišta predstavlja transformiranje stručnih programa u sveučilišne programe više različitih zdravstvenih profesija" (MZOS, 12. lipnja 2013., klasa 602-04/13-10/00064). Sve je to

\section{Foreword from the Dean of the University of Applied Health Sciences}

The University of Applied Health Sciences has for decades undoubtedly been an institution that could not have been avoided in the vocational and professional education and development of various health professionals. We are proud to say that following the introduction of the State Matura Exam the interest of secondary school students to continue their studies at one of the University's six study programmes has been increasing greatly. In 2015 the study of physiotherapy has been the most sought-after study programme with the highest number of applicants making it their "first choice" of study. The study of radiological technology has also ranked among the ten most popular and certainly the most challenging study programmes for State Matura graduates. This is due to long-term efforts of all current and former teachers, students and employees, who have embedded their work and knowledge, as well as a significant part of their life, into the foundations of this institution.

Without false modesty, we rightly deserve what the Minister of Science, Education and Sport stated in 2013 in a written document and which clearly pointed out that "in almost half a century of its development the University of Applied Health Sciences has become a leading institution in the higher education of health workers."

The University of Applied Health Sciences is the legal successor of the School of Health Studies, which was built on the foundations of the Advanced School of Nursing and Health Technicians founded in Zagreb in 1966. In the circumstances of great demand for a higher level of education of health professionals which had up to then been educated at secondary school level, the Advanced School of Nursing and Health Technicians was the only higher education institution in Croatia that offered the education of hospital and visiting nurses, as well as ra- 
logičan put razvoja ustanove koja se ponosi svojom stožernom ulogom u obrazovanju medicinskih sestara, fizioterapeuta, sanitarnih inženjera i ostalih profila zdravstvenih radnika bez kojih sustav zdravstvene zaštite ne bi mogao postojati.

U ovom mandatu Upravno vijeće s dekanom, kao jednim među ravnopravnima, preuzelo je odgovornost nastaviti i dovršiti započete procese transformacije $u$, sasvim logično, sveučilišnu sastavnicu najstarijeg sveučilišta u ovom dijelu Europe - Sveučilišta u Zagrebu.

U skladu s rečenim donesena je nova Strategija razvoja Zdravstvenog veleučilišta i Operativni plan njezine realizacije za period 2015. - 2020. Redefinirana je misija Veleučilišta organizirati i izvoditi kvalitetne studijske programe na stručnoj, a u skoroj budućnosti i sveučilišnoj razini visokoškolskog obrazovanja i tim putem doprinijeti unaprjeđenju zdravstvenih i etičkih standarda, kvaliteti zdravstvenih usluga, smanjenju zdravstvene potrošnje, unaprjeđenju humanijih odnosa u zdravstvu i zaštiti prava pacijenata. Ovu misiju ustanova ostvaruje izvođenjem studijskih programa kvalitetom i sadržajem prilagođenih europskim standardima, suvremenom organizacijom i kvalitetnim izvođenjem nastave, uz primjenu novih medicinskih i informacijskih tehnologija. Ostvarivanju misije pridonosi i razvoj i implementacija sustava kvalitete kojim je osigurana učinkovitost sustava i optimalno korištenje postojećim resursima i osiguravanje novih te unaprjeđenje kvalitete nastavnog procesa temeljenog na kompetencijama i usmjerenog prema optimalnoj realizaciji programa mjerenoj ishodima učenja, rezultat čega su najkvalitetniji kadrovi za čitav zdravstveni, ali i obrazovni i znanstveni sustav.

Uspjeh ustanove mjeren je činjenicom da naši prvostupnici i diplomanti postaju kompetentni, a time i konkurentni na tržištu rada na kojem su na temelju stečenih kompetencija cijenjeni članovi interdisciplinarnih timova u kojima se ističu svojom sposobnošću sagledavanja, analize i rješavanja najsloženijih zadataka te postaju važna pokretačka snaga u sustavu zdravstva i društvu u cjelini usmjerenom k razvoju društva znanja, tolerancije i jednakih mogućnosti.

Vizija je izgrađivati ovu ustanovu prema tome da postane sastavnica Sveučilišta, kao samostalni pravni subjekt s punom autonomnošću i samoopstojnošću kako u akademskom tako i pravnom dijelu, te je razvijati kao vodeću visokoškolsku ustanovu na području zdravstvenog obrazovanja za neliječnički kadar, prepoznatu po svojoj izvrsnosti u Hrvatskoj, u zemljama regije i u Europi. diologic, environmental health and laboratory technicians at the former associate level.

Based on the 50 years of the University's history, its founder, the Ministry of Science, Education and Sports, has emphasized that "the strategic determination and development of the University is the transformation of professional programmes into university programmes for different health professions" (MSES, 12 June 2013. Class: 602-04 / 13-10 / 00064 ). All this represents a logical course of the institution's development which takes pride in its pivotal role in the education of nurses, physiotherapists, environmental health engineers and other health professionals without which the health care system could not exist.

In this mandate, the Governing Council together with the Dean has assumed the responsibility as an equal stakeholder to continue and complete the initiated transformation processes into a constituent unit of the oldest University in this part of Europe the University of Zagreb.

In accordance with the aforesaid, The University has adopted the new Development Strategy and the Operational Plan for its implementation for the period 20152020. The redefined mission of the University is to organize and carry out quality study programmes at the professional, and in the near future, university level, and in this way contribute to the improvement of health and ethical standards, quality health services, lower health care costs, improvement of the humane relationships in health and protection of patients' rights. This mission is achieved by offering study programmes whose quality and content have been adjusted to European standards and by modern organization of quality teaching process which makes use of new medical and information technologies. The development and implementation of a quality system also contributes to the realization of the mission. It ensures the efficiency of the system and optimal use of the existing resources and securing the new ones, improving the quality of the teaching process based on competencies and oriented towards the optimal implementation of the programmes based on learning outcomes, the result of which is top-quality personnel not only in the health system, but in the educational and scientific systems as well.

The success of the institution can be measured by the fact that our graduates become competent professionals, which can consequently compete in the labour market where they are valued members of interdisciplinary teams in which they stand out for their abil- 
U realizaciji ove vizije predviđena je implementacija najviših standarda kvalitete te jaka suradnja sa srodnim visokoškolskim ustanovama u regiji i u zemljama EU-a, temeljena na visokom stupnju mobilnosti nastavnika i studenata, na razvoju zajedničkih studija i na provođenju zajedničkih stručnih i primijenjenih znanstvenih istraživanja.

Čvrst zalog za budućnost leži u naših 12 akreditiranih studijskih programa koje su u prošloj akademskoj godini, pohađala 3204 studenta, naša najveća dragocjenost i potencijal; od toga 1083 redovna i 2121 izvanredni student (1962 na dodiplomskim i 159 na diplomskim studijima), za koje je izvedeno 108355 norma sati nastave.

Snaga i konkurentska prednost ove ustanove uhodana je mreža radilišta u kojima radi gotovo 750 nastavnika i suradnika izabranih u nastavna i znanstveno-nastavna zvanja. Budućnost su razvoja ustanove naših 36 nastavnika koje je Veleučilište većinom uputilo na doktorske ili manjim dijelom na poslijediplomske studije u Hrvatskoj i zemljama EU-a, koji će, kada uskoro obrane svoje doktorske disertacije, znatno ojačati znanstveno nastavni kadar. Svi su zajedno snaga i jamstvo koja će ostvariti preustroj ustanove na sveučilišnu razinu.

Potvrda korporativne vrijednosti Zdravstvenog veleučilišta potvrđena je i 17. prosinca 2013. dodjelom oznake DS za razdoblje 2013. - 2016. koja se dodjeljuje kao priznanje visokog stupnja transparentnosti i pouzdanosti u primjeni Dopunske isprave o studiju. Označava da se u Zdravstvenom veleučilištu valjano primjenjuju dopunske isprave o studiju, što je ujedno važna poruka studentima o vrednovanju transnacionalne mobilnosti.

Zdravstveno veleučilište registrirano je i kao znanstvena ustanova i kroz prošlost bilo je nositelj niza uspješnih znanstvenih projekata. Međutim pod pritiskom nastavnih normi koje su višestruko više nego na sveučilištu, znanstveno publiciranje s vremenom nije pratilo kvantitetom, ne i kvalitetom, standarde koji se očekuju u znanstvenoj zajednici. Naime smatramo da su stručni i znanstvenoistraživački rad te stručna i znanstvena produkcija važna mjera vrijednosti i uspješnosti svake visokoškolske ustanove, ali također i osnova na kojoj počiva sam opstanak akademske zajednice, te su stoga važan sastavni dio redovitih obveza nastavnika, čime se nastoji doprinijeti porastu ukupnog znanja i proširenju kompetencija, individualnom profesionalnom razvoju i transferu znanja, kao i afirmaciji Zdravstvenog veleučilišta.

U cilju daljnjeg unaprjeđenja postojećeg stanja kroz poticanja svih oblike publiciranja radova nastavnika i su- ity of observation, analysis and resolution of the most complex tasks due to acquired competences and thus become an important driving force in the health system and society oriented towards the development of a knowledge society, and the society of tolerance and equal opportunities.

The vision of the institution is to become a constituent unit of the University of Zagreb, as an independent legal entity with full autonomy and self-existence in both academic and legal domains, and to develop as the leading institution in the field of health education for non-medical staff, recognized for its excellence in Croatia, the region and Europe.

The fulfilment of this vision provides for the implementation of the highest standards of quality, intensive cooperation with similar regional and EU institutions of higher education, based on a high level of teacher and student mobility, development of joint study programmes and joint professional and applied scientific research.

A solid investment in the future lies in our 12 accredited study programmes which were in the last academic year attended by 3204 students - our greatest treasure and potential. Out of those 3024 students, 1083 were full-time and 2121 part-time students (1,962 at undergraduate and 159 at graduate study programmes), with additional 668 senior students who have completed all their course obligations, and the total of 108355 teaching hours held.

The strength and competitive advantage of this institution is an established network of teaching sites that employ nearly 850 teachers and associates elected into teaching and scientific-teaching positions. The future of our institution's development lies in the 36 teachers whose doctoral and master studies in Croatia and the EU countries are funded by the University and who will considerably strengthen the structure of the scientific and teaching staff upon the completion of their studies. All of them are the strength and guarantee for the transition of the institution to a university level.

The corporate value of the University of Applied Health Sciences was also confirmed on 17 December 2013 when it was awarded the DS label for the period 20132016. DS label is awarded in recognition of a high degree of transparency and reliability in the use of the Diploma Supplement. It signifies that the University duly applies Diploma Supplements, which is at the same time an important message to students about the evaluation of transnational mobility. 
radnika ove ustanove (samostalno, u suradnji s drugim djelatnicima Veleučilišta, s osobama iz drugih domaćih i inozemnih znanstvenih i obrazovnih ustanova), a posebno zajedničko objavljivanje radova sa studentima Veleučilišta, Uprava Veleučilišta na poticaj dekana i voditelja Službe za znanstvena i stručna istraživanja prije godinu dana donijela je odluku o pokretanju vlastitoga znanstvenog časopisa s međunarodnom orijentacijom i vrlo profiliranim Savjetom i profesionalnim uredništvom, postavivši ljestvicu znatno više od realizacije davne ideje o izdavanju glasila ili kućnog časopisa.

Pred vama je prvi broj časopisa za koji sam uvjeren da će ga naši studenti i naša djeca u desetljećima koja dolaze čuvati i razvijati. Čeka nas mukotrpan put, no posve sam siguran da je Konfucije bio u pravu govoreći: „Usprkos svemu, ako svakog dana ponesemo kanticu zemlje na jedno mjesto, sagradit ćemo planinu."

Uvjeren sam da zajedno možemo razviti časopis kojim ćemo se nakon isteka naših uredničkih i upravljačkih mandata ponositi pred samima sobom, pred svojim studentima i pred svojom djecom.

\section{Dekan Zdravstvenog veleučilišta Zagreb Dr. sc. Aleksandar Racz, prof. v. š.}

The University of Applied Health Sciences is registered as a scientific institution and in the past it was the holder of a number of successful research projects. However, under the pressure of the teacher workload that is much higher than University level standards, scientific publication did not satisfy only the quantity standards expected in the scientific community. Namely, we believe that the professional, scientific and research work and production are important measures of value and success of any higher education institution. They are also the basis on which the very survival of the academic community depends, and are therefore an important component of the current obligations of teachers and aim to contribute to the increase of overall knowledge, expansion of competencies, individual professional development and knowledge transfer, as well as the affirmation of the University of Applied Health Sciences.

In order to further improve the existing situation through encouraging all forms of publication of teachers and associates (individual and joint publication with other employees of the University of Applied Health Sciences and individuals from other national and foreign scientific and educational institutions), and in particular joint publication with the University's students - a year ago, on the initiative of the Dean and the Head of the Office for Professional and Scientific Research, the Management Board of the University adopted a decision to launch its own international scientific journal with carefully chosen Advisory and Editorial Boards thus setting the bar much higher in comparison with the previous idea about the institution's own bulletin or periodical.

What you have before you is the first issue of the journal for which I am convinced will be maintained and developed by our students and our children in the coming decades. We have a difficult path ahead of us, but I am quite certain that Confucius was right when he said that "the man who moves a mountain begins by carrying away small stones".

I believe that together we can create a journal which, after our editorial and management mandates expire, will not only make us proud of ourselves, but will make our students and children proud of us as well.

Dean of the University of Applied Health Sciences Aleksandar Racz, PhD 


\section{Je li tjelesna aktivnost studenata Zdravstvenog veleučilišta povezana $s$ njihovim osobinama ličnosti?}

\author{
1 Janko Babić \\ 1 Melita Rukavina \\ 1 Morana Bilić \\ 1 Katedra za zdravstvenu psihologiju, \\ Zdravstveno veleučilište, Zagreb
}

\section{Sažetak}

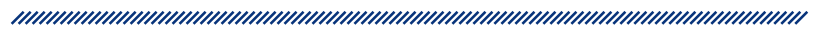

Cilj rada bio je ustanoviti stupanj bavljenja tjelesnom aktivnošću studenata Zdravstvenog veleučilišta, kao i eventualne spolne razlike $u$ tjelesnoj aktivnosti, te pobliže ispitati odnos tjelesne aktivnosti i određenih osobina ličnosti (sramežljivost, samopoštovanje, ekstroverzija, neuroticizam).

Ispitan je 341 student (264 ženskog spola, 77 muškog) Zdravstvenog veleučilišta u Zagrebu, prosječne dobi 20,65 godina. Sklop upitnika sastojao se od Baeckeova upitnika tjelesne aktivnosti (Baecke Questionnaire of Habitual Physical Activity, 1982), Skale sramežljivosti (Cheek i Buss 1981), Rosenbergove skale samopoštovanja (Rosenberg Self-Esteem Scale, 1965) te Eysenckova upitnika ličnosti (Eysenck Personality Questionairre, 1975).

Rezultati su pokazali da su studenti Zdravstvenog veleučilišta prosječno tjelesno aktivni te su muškarci tjelesno aktivniji od žena. Nadalje, ustanovljena je pozitivna povezanost između stupnja bavljenja tjelesnom aktivnošću i ekstroverzije te samopoštovanja, a negativna između stupnja bavljenja tjelesnom aktivnošću i sramežljivosti.

\begin{abstract}
Može se zaključiti da bi dodatne analize trebale istražiti pravu strukturu povezanosti osobina ličnosti i stupnja tjelesne aktivnosti, no ona bez sumnje postoji te bi se time trebali voditi stručnjaci pri izradi planova i programa povećanja tjelesne aktivnosti kako u studentskoj tako i u općoj populaciji.
\end{abstract}

Ključne riječi: tjelesna aktivnost, sramežljivost, samopoštovanje, ekstroverzija, neuroticizam

Datum primitka: 23.04.2015.

Datum prihvaćanja: 08.09.2015.

Adresa za dopisivanje:

Janko Babić, prof.psih.

Zdravstveno veleučilište

Ksaver 209, Zagreb

Tel.: 0914595734

E-pošta:janko.babic@zvu.hr

\section{Uvod}

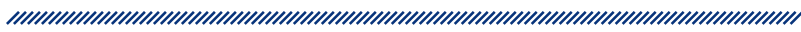

Dobro je poznato da tjelesna aktivnost i vježbanje pozitivno djeluju na blagu i umjerenu depresiju, pomažu u liječenju alkoholizma i ovisnosti o drogama, poboljšavaju samopoimanje, socijalne vještine i kognitivno funkcioniranje, smanjuju anksioznost i utječu na bolje 
suočavanje sa stresom ${ }^{1}$. Trenutačna znanstvena saznanja uvjerljivo pokazuju da tjelesna neaktivnost, koja je u različitom stupnju prisutna u najvećem dijelu populacije većine svjetskih zemalja, predstavlja ozbiljnu opasnost za zdravlje, funkcionalnu sposobnost i kvalitetu života, a čak se ubraja među tri vodeća razloga za razvitak brojnih bolesti, smrti ili invalidnosti, uz neodgovarajuću prehranu i pušenje ${ }^{2}$. Prema Burgos-Garrido i sur. ${ }^{3}$, podaci WHO-a (2009) pokazuju da je tjelesna neaktivnost diljem svijeta četvrti rizični faktor smrtnosti. $U$ Hrvatskoj je situacija također alarmantna jer oko $83 \%$ ljudi nije dovoljno tjelesno aktivno ${ }^{4}$.

S druge strane, bilo direktno bilo kroz učinke promjena raspoloženja, vježbanje jasno utječe na smanjenje tjelesne težine i sprječava razvitak pretilosti. Tjelesno vježbanje povećava opskrbu stanica kisikom te tako dovodi do raspada slobodnih radikala. Također podiže razinu psihofizičkih i funkcionalnih sposobnosti, koje su osnovni pokazatelj stupnja zdravlja. Redovita tjelesna aktivnost povećava kvalitetu života na fiziološkom i psihološkom planu. Utjecaj na stupanj tjelesne aktivnosti trebao bi biti prioritet javnog zdravstva, a poznavanje i razumijevanje individualnih osobina (sociodemografskih, psiholoških, kognitivnih i emocionalnih), zajedno sa socijalnim, kulturalnim i okolinskim faktorima koji potencijalno utječu na tjelesnu aktivnost, temelj je razvijanja uspješnih intervencija koje bi imale tu svrhu (Masse i sur. 2011; prema ${ }^{3}$ ).

Nedavna istraživanja u Americi pokazuju da su studenti i dalje relativno neaktivni te da mnogi ne ispunjavaju preporuke o minimalnoj dnevnoj aktivnosti. Butler i sur. ${ }^{6}$ svojim su istraživanjem potvrdili pretpostavku da se stupanj tjelesne aktivnosti smanjuje prelaskom iz srednje škole na fakultet, dok su Huang i sur. ${ }^{7}$ pokazali da studenti vježbaju manje od tri dana tjedno. Također, dobivena su saznanja o tome da je većina studentskih aktivnosti sedentarna te da polovica od toga otpada na učenje. U Hrvatskoj je istraživanje Pedišića ${ }^{8}$ pokazalo da je prevalencija nedovoljne razine tjelesne aktivnosti u studentskoj populaciji veća od $39 \%$.

Stoga je iznimno važno prepoznati čimbenike koji utječu na bavljenje tjelesnom aktivnošću pojedinaca. Sramežljivost je osobina ličnosti koja određuje i usmjerava ponašanje pojedinca te ćemo ispitati na koji je način povezana s vježbanjem i tjelesnom aktivnošću.

Briggs i suradnici (1985; prema Zarevski i Mamula 1998) određuju sramežljivost kao pretjeranu i neurotsku pozornost usmjerenu na sebe u socijalnim situacijama, što dovodi do plašljivog i često neprimjerenoga manifesnog ponašanja, a dovodi i do emocionalnih i kognitiv- nih promjena (poremećaja) te je povezana s anksioznošću i niskim samopoštovanjem. Ono što je zajedničko svim sramežljivima akutna je samosvijest. Provode toliko vremena fokusirajući se na sebe i svoje slabosti da imaju malo vremena ili volje usmjeriti se prema van ${ }^{10}$. Sramežljivost je kompleksnija nego strah od javnog nastupa, koji katkad osjećaju i najotvoreniji ljudi. Jednostavno rečeno, sramežljivost rezultira iz ekstremne samosvijesti i negativnog razmišljanja. No nije ista kao nisko samopoštovanje; mnogi sramežljivi poprilično su sigurni u svoje sposobnosti izvan okvira nepoznatih socijalnih situacija. Sramežljivost kao osobina ličnosti ukazuje na relativno trajan oblik sramežljivog odgovora pojedinca kojim pojedinac može reagirati i reagira u većini situacija. U skladu s tim, sramežljive će osobe u većini situacija iskazati sramežljivo ponašanje češće od nesramežljivih ${ }^{9}$. Od kognitivnih problema sramežljivu osobu uvijek prati briga o vlastitu položaju u prisutnosti drugih: hoće li nešto pogrešno reći ili učiniti, hoće li biti u stanju razmisliti i nešto reći. Općenito, sramežljivu osobu prate razmišljanja i vlastita percepcija osobne nekompetentnosti, nespretnosti, nedostatka vještine i sl. Uz ove probleme, sramežljivi se u pravilu susreću s problemom nemogućnosti brzog procesiranja i efikasnog donošenja odluka (odnosno reagiranja) u situacijama prisutnosti drugih ljudi. Na emotivnom planu sa sramežljivošću ruku pod ruku idu napetost, tjeskoba, osamljenost i potištenost. U težim se slučajevima javljaju i jaka depresivna stanja, osobito kod žena9.

S obzirom na sve navedeno, za očekivati je da će sramežljivije osobe biti manje sklone tjelesnim aktivnostima jer u većini slučajeva uključuju socijalnu komponentu i interakciju s drugim ljudima, pogotovo u situaciji timskih ili grupnih aktivnosti. Također, visoka samosvijest i strah od javnih nastupa može biti izražena u tolikoj mjeri da izrazito sramežljive osobe odustanu od profesionalnog bavljenja sportom. Istraživanje Page i Zarco ${ }^{11}$ pokazalo je da su adolescenti s višim stupnjem sramežljivosti značajno manje sudjelovali u intenzivnim tjelesnim aktivnostima nego oni sa srednjim i nižim stupnjem sramežljivosti.

Također, sramežljiviji su bili manje skloni baviti se momčadskim sportovima. Jednaka je povezanost dobivena i istraživanjem provedenim na američkim i na filipinskim srednjoškolcima. U još jednom istraživanju provedenom na američkim adolescentima (Page i Hammermeister 1995; prema Page i Zarco 2001 ${ }^{11}$ ) također se pokazalo se da je stupanj sramežljivost negativno povezan s učestalošću bavljenja tjelesnom aktivnošću.

Sljedeći je psihološki konstrukt čiju ćemo povezanost $\mathrm{s}$ tjelesnom aktivnošću istražiti samopoštovanje. Uo- 
bičajeno ukazuje na vrednovanje i osjećaje povezane s vjerovanjima i mišljenjima o sebi. Osoba visokog samopoštovanja „osjeća se dobro" kad razmišlja o sebi, cijeni se, smatra se vrijednim - općenito ima pozitivno mišljenje o sebi, dok se osoba niskog samopoštovanja „osjeća loše“ kad razmišlja o sebi, najčešće ne prihvaća sebe, podcjenjuje se u većini aspekata, općenito ima negativno mišljenje o sebij ${ }^{12}$. Šire poimanje samopoštovanja obuhvaća osjećaje o osobnim vještinama, mogućnostima i društvenim odnosima te je uloga samopoštovanja u strukturi pojma o sebi suočavanje pojedinca s vanjskim informacijama, odnosno samopoštovanje je za pojedinca određeni „mehanizam zaštite“ kroz koji vrednuje sebe i svijet. Visoko samopoštovanje općenito je povezano s pozitivnim mentalnim ishodima kao što su sposobnost nošenja s problemima te također s manjom vjerojatnošću pojavljivanja depresije (Coatsworth i Convoy 2006; prema Bungić i Barić 2009 ${ }^{13}$ ).

Može se zaključiti da postoji značajna povezanost između tjelesne aktivnosti i povišene razine samopoštovanja, jer osobe koje se bave određenom vrstom tjelesnog vježbanja imaju priliku kroz svoju aktivnost povećati ili čak i izgraditi svoje samopoštovanje, dok osobe koje nisu sklone tjelesnim aktivnostima nemaju priliku na ovaj način utjecati svoje samopoštovanje. Strauss i sur. ${ }^{14}$ u svojem su istraživanju spoznali da povećana razina tjelesne aktivnosti već kod djece igra važnu ulogu u razvitku njihova samopoštovanja. Istraživanje koje su u Valenciji na studentima tamošnjeg sveučilišta proveli Castillo i Garcia-Molina ${ }^{15}$ potvrdilo je rezultate drugih istraživanja o pozitivnoj povezanosti tjelesne aktivnosti i slike o sebi. Općenito, može se reći da razina samopoštovanja sportaša/vježbača ovisi o raznim faktorima kao što su uključenost, doživljaj uspjeha, zadovoljstvo izgledom, motiviranost i anksioznost ${ }^{13}$.

Uz sramežljivost i samopoštovanje, a u cilju što preciznijeg određenja čimbenika koji utječu na bavljenje tjelesnom aktivnošću, svakako bi trebalo ispitati jesu li među tim čimbenicima i neke bazične, univerzalne dimenzije ličnosti. Teorijski je model kojim smo se koristili u ovom istraživanju Eysenckov trofaktorski model ličnosti PEN koji pretpostavlja postojanje triju velikih faktora, poimence P - psihoticizma, E -ekstroverzije i N - neuroticizma. S obzirom na to da u dosadašnjim istraživanjima nije pronađena veza između dimenzije psihoticizma i stupnja tjelesne aktivnosti ${ }^{16,17}$, u ovom ćemo radu istražiti samo povezanost dimenzija ekstroverzije $\mathrm{i}$ neuroticizma s tjelesnom aktivnošću pojedinaca.

Zbog inhibicije središnjega živčanog sustava, ekstrovertiraniji su pojedinci u stalnoj potrazi za podražajima kako bi razinu pobuđenosti doveli na optimalnu razi$n^{18}$. Izraziti su ekstroverti društveni, vole zabave, imaju mnogo prijatelja, rado komuniciraju s ljudima, čeznu za uzbuđenjima, vole riskirati te su općenito impulzivni. Vole stalno biti u pokretu i nešto raditi, no ne kontroliraju dobro osjećaje i znaju biti nepouzdani. S druge strane, izraziti introverti imaju prirodno ekscitiran središnji živčani sustav te su tihi, povučeni, više vole čitati nego se družiti s drugim ljudima, voli planirati unaprijed, ne vole uzbuđenja, strogo kontroliraju osjećaje te su pouzdani.

S obzirom na karakteristike dimenzije ekstroverzije može se pretpostaviti da će se ekstrovertiraniji pojedinci, u potrazi za uzbuđenjem, češće odlučivati na razne tjelesne aktivnosti, dok će ih introvertiraniji pojedinci izbjegavati, pogotovo one koje sa sobom nose mnogo uzbuđenja. Rezultati istraživanja koje su proveli Burgess i Pargman ${ }^{19}$ potvrdili su takve pretpostavke, pokazavši da oni koji se često i umjereno bave tjelesnom aktivnošću postižu više rezultate na dimenziji traženja uzbuđenja od onih koji se ne bave te da je ekstroverzija pozitivno povezana s traženjem uzbuđenja.

Glavna je osobina osobe koja je postigla visok rezultat na skali neuroticizma stalna zabrinutost i okupiranost stvarima koje bi mogle krenuti po zlu. Zbog takvih se misli javlja izrazita anksioznost. Takve će osobe biti previše emocionalne, burno će reagirati na svaki podražaj te će im takve snažne reakcije otežavati prilagodbu $i$ uzrokovati iracionalno, katkada rigidno ponašanje ${ }^{18}$. Nasuprot tome, emocionalno stabilna osoba reagira polako i općenito slabim emocionalnim reakcijama te se brzo pribere nakon uzbuđenja. Obično je mirna, blage ćudi, dobro se kontrolira i nije zabrinuta.

Istraživanje koje su proveli Kirkcaldy i Furnham ${ }^{17}$, a kojim su htjeli ispitati povezanost neuroticizma s afinitetima prema rekreaciji, pokazalo je da se oni koji su tjelesno aktivni značajno razlikuju od onih koji to nisu u stupnju neuroticizma, pri čemu aktivniji postižu niži rezultat na skali neuroticizma. Rhodes i Smith ${ }^{16}$ proveli su metaanalizu 33 istraživanja koja su se bavila povezanošću osobina ličnosti i tjelesne aktivnosti.

Pokazalo se da je dimenzija neuroticizma negativno povezana $s$ učestalošću bavljenja tjelesnom aktivnošću. Očito je da su osobe koje su sklone brizi te burnim i nestabilnim emocionalnim reakcijama manje sklone baviti se tjelesnim aktivnostima.

Znanstvenici se već posljednjih 50 godina bave odnosom ličnosti i tjelesne aktivnosti ${ }^{20}$. Bavili su se širokim spektrom tog odnosa, od toga je li tjelesna aktivnost povezana s ličnošću, kako je ličnost povezana s motiva- 
cijom i preprekama za bavljenje tjelesnom aktivnošću te kako je ličnost povezana sa stanjem nakon vježbanja. I danas se pokušava utvrditi je li ličnost determinanta tjelesne aktivnosti i na koji je način s njom povezana.

Dosadašnja su istraživanja konzistentna u tome da je ekstroverzija pozitivno povezana s tjelesnom aktivnošću te nešto manje $u$ tome da je neuroticizam negativno povezan s njom, dok u slučaju psihoticizma povezanost nije nađena. Također treba napomenuti da su kroz istraživanja korelacije između osobina ličnosti i tjelesne aktivnosti uglavnom male do umjerene ${ }^{19}$.

U ovom ćemo radu pobliže ispitati odnos tjelesne aktivnosti i ranije navedenih osobina ličnosti, ali i općenito ustanoviti stupanj bavljenja tjelesnom aktivnošću studenata Zdravstvenog veleučilišta, kao i eventualne spolne razlike u njemu.

\section{Metode}

\section{Sudionici}

$\mathrm{U}$ istraživanju je sudjelovao 341 student Zdravstvenog veleučilišta u Zagrebu. Uzorak je bio prigodan te su u sklopu istraživanja ispitani studenti studija sestrinstva $(\mathrm{N}=226)$, radiologije $(\mathrm{N}=72)$ i fizioterapije $(\mathrm{N}=42)$. Od ukupnog je broja sudionika 264 bilo ženskog, a 77 muškog spola. Raspon dobi bio je od 18 do 48 godina, a prosječna je dob iznosila 20,65 godina.

\section{Instrumentarij}

1. Baeckeov upitnik tjelesne aktivnosti (Baecke Questionnaire of Habitual Physical Activity, 1982)

Baeckeov upitnik jedan je od jednostavnih, ali dobro konstruiranih upitnika koji pažljivo analizira najčešće oblike tjelesne aktivnosti. Ovaj upitnik na osnovi ciljanih pitanja o trajanju, intenzitetu i učestalosti različitih tjelesnih aktivnosti nudi utvrđivanje tjelesne aktivnosti povezane s radnim mjestom, sportskim aktivnostima, kao i drugim tjelesnim aktivnostima u slobodnom vremenu ${ }^{21}$. Baeckeov upitnik sastavljen je od 16 pitanja koja obuhvaćaju uobičajenu tjelesnu aktivnost u proteklih 12 mjeseci. Za potrebe ovog istraživanja u upitnik nije uključeno pitanje o mjestu rada jer se ispitivalo opterećenje na nastavi. Pitanja su sastavljena na način da omogućavaju utvrđivanje triju različitih dimenzija tjelesne aktivnosti: tjelesna aktivnost na radu, odnosno u ovom slučaju na nastavi - procijenjena s pomoću sedam pitanja, sportska tjelesna aktivnost - procijenjena s pomoću četiri pitanja i tjelesna aktivnost u slobodnom vremenu koja u sebi ne sadržava bavljenje sportom (npr. hodanje, vožnja bicikla) - procijenjena s pomoću četiri pitanja. Na osnovi odgovora izračunana su tri odgovarajuća indeksa: radni indeks, odnosno indeks opterećenja na nastavi (engl. work index WI), sportski indeks (engl. sport index - SI) i indeks slobodnog vremena (engl. leisure index - LI).

- Radni indeks procjenjuje tjelesnu aktivnost tijekom radnog vremena (npr. „Na nastavi sjedim“, odgovori od 1 - nikad do 5 - uvijek), a dobiva se tako da se zbroje bodovi za prvih osam pitanja te se dobiveni zbroj podijeli s osam (koeficijent unutarnje konzistencije Cronbach $\alpha=0,72$ ).

- Indeks sporta procjenjuje količinu sportske aktivnosti u slobodno vrijeme (npr. „Koliko se sati tjedno bavite sportom?“, odgovori od „manje od $1 \mathrm{~h}$ “ do „više od $4 \mathrm{~h}$ “), a dobiva se zbrajanjem bodova za pitanja od 9. do 12. te dijeljenjem dobivenog zbroja s četiri. (koeficijent unutarnje konzistencije Cronbach $\alpha=0,68$ ).

- Indeks slobodnog vremena procjenjuje količinu tjelesne aktivnosti u slobodno vrijeme (isključujući sportsku aktivnost, npr. „U slobodno vrijeme gledam TV", odgovori od 1 - nikad do 5 - vrlo često), a dobiva se zbrajanjem bodova za pitanja od 13. do 16. te dijeljenjem dobivenog zbroja s četiri (koeficijent unutarnje konzistencije Cronbach $\alpha=0,47$ ).

$\mathrm{Na}$ taj način minimalna vrijednost pojedinog indeksa iznosi 1, a maksimalna 5. Zbrajanjem vrijednosti navedenih triju indeksa dobivamo vrijednost indeksa ukupne aktivnosti kojem pripisujemo minimalno 3, a maksimalno 15 bodova. Cronbachov alpha koeficijent dobiven na cijeloj skali iznosi 0,64 . Baeckeov upitnik primijenjen je u brojnim istraživanjima te se smatra jednim od najpouzdanijih upitnika za procjenu tjelesne aktivnosti ${ }^{2}$.

\section{Skala sramežljivosti (Cheek i Buss, 1981)}

Skala mjeri sramežljivost, koja se u razmatranjima Cheeka i Bussa (1981; prema Burušić 1999²3) određuje kao "neugoda i inhibiranost koju osoba doživljava u prisutnosti drugih". Čestice su formulirane na način da mjere afektivne i ponašajne aspekte 
sramežljivosti. U istraživanju je rabljena revidirana verzija Skale sramežljivosti koja ima 13 čestica (npr. „U društvu se osjećam sputano“). Format je za odgovaranje skala Likertova tipa s pet stupnjeva, a ukupni se rezultat formira zbrajanjem kao linearna kombinacija svih čestica u skali, uz prethodno obrnuto bodovanje za četiri čestice, u smjeru da veći rezultat upućuje na izraženiju sramežljivost. Teorijski se raspon rezultata može kretati od minimalnog 13 , koji upućuje na izrazito nisku sramežljivost, do maksimalnog rezultata 65 , koji upućuje na izrazito veliku sramežljivost (u ovom se radu ukupni rezultat prikazivao izražen u rasponu od 1 do 5). Ovaj instrument odlikuju u prvom redu izrazito zadovoljavajuće metrijske karakteristike te vrlo kratko vrijeme potrebno za primjenu. Cheek i Buss (1981; prema Burušić 199923) navode iscrpne podatke koji idu u prilog konvergentnoj i divergentnoj valjanosti ovog instrumenta za mjerenje sramežljivosti, no cjelovito razmatranje rezultata dobivenih ovom skalom ukazuje na to da i ovaj instrument dijelom karakteriziraju problemi zajednički većini sličnih instrumenata, koji se manifestiraju u prvom redu u konceptualnom razgraničenju sa sličnim instrumentima namijenjenima mjerenju socijalne anksioznosti, socijalnog izbjegavanja i sl. $\mathrm{U}$ ovom su istraživanju provjere metrijskih karakteristika demonstrirale također već znane karakteristike ovoga instrumenta - koeficijent je unutarnje konzistencije zadovoljavajući, iskazan Cronbachovim alpha koeficijentom iznosi 0,80.

3. Rosenbergova skala samopoštovanja (Rosenberg Self-Esteem Scale, 1965)

Skala mjeri globalnu vrijednosnu orijentaciju prema sebi, a ne specifične aspekte samopoštovanja. Autori su je godinama upotrebljavali u istraživanjima i pokazalo se je da pouzdano mjeri globalno samopoštovanje ${ }^{24}$. Sadrži deset čestica (npr. „Mislim da vrijedim barem koliko i drugi ljudi“) na koje se odgovara na skali Likertova tipa s četiri stupnja (od 1 do 4). Ukupni se rezultat formira kao linearna kombinacija procjena na svakoj od čestica. Prije sumiranja procjena potrebno je neke od tvrdnji koje označavaju nedostatak samopoštovanja obrnuto bodovati. Tako viši rezultat označava više samopoštovanje, a rezultati se kreću u rasponu od 10 do 40 (u ovom se radu ukupni rezultat prikazivao izražen u rasponu od 1 do 4). Dobiveni koeficijent unutarnje konzistencije, Cronbachov alpha koeficijent, iznosi 0,71.

\section{Eysenckov upitnik ličnosti (Eysenck Persona- lity Questionairre, 1975)}

Za ispitivanje ličnosti primijenjen je Eysenckov upitnik EPQ ${ }^{18}$ koji se temelji na Eysenckovu trofaktorskom modelu PEN koji mjeri tri dimenzije ličnosti (ekstroverziju, neuroticizam i psihoticizam) te sklonost davanju socijalno poželjnih odgovora (skala laži). Upitnik se sastoji od ukupno 90 čestica na koje su ponuđeni odgovori DA i NE. Dimenziju ekstroverzije mjeri 21 čestica (npr. „Jeste li u društvu obično povučeni?“) te se ukupni rezultat, dobiven kao zbroj odgovora na njih, može kretati u rasponu od 0 do 21 (dobiveni Cronbachov alpha koeficijent iznosi 0,73), dimenziju neuroticizma mjere 23 čestice (npr. „Jeste li razdražljivi?"; rezultat od 0 do $23, \alpha=0,76$ ), dimenziju psihoticizma 25 čestica (npr. „Volite li ponekad dražiti životinje?"; rezultat od 0 do 25 , $\alpha=0,60)$, dok se skala laži sastoji od 21 čestice (npr. „Jesu li sve vaše navike dobre i poželjne?“; od 0 do 21 boda, $\alpha=0,69$ ).

U sklopu istraživanja prikupljeni su i određeni sociodemografski podatci (spol, dob, visina, težina, studij, godina studija). Također, jednom je česticom mjerena i samoprocjena zdravlja (Likertova skala, ponuđeni odgovori od 1 - uopće nisam zadovoljan svojim zdravljem do 5 - u potpunosti sam zadovoljan svojim zdravljem), kao i stupanj zadovoljstva bavljenja tjelesnom aktivnošću (1 - uopće nisam zadovoljan; 5 - u potpunosti sam zadovoljan).

\section{Postupak}

Istraživanje je provedeno u travnju 2012. godine na studentima Zdravstvenog veleučilišta. Podatci su prikupljani grupno, u sklopu nastave, uz prethodno odobrenje Etičkog povjerenstva Zdravstvenog veleučilišta. Na početku je sudionicima dano pisano objašnjenje o svrsi istraživanja te je tražena njihova pisana suglasnost o sudjelovanju u njemu. U sklopu toga im je i napomenuto da njihovo neslaganje sa sudjelovanjem u ovoj studiji neće imati nikakvih posljedica na njihovo studiranje ni na odnos nastavnika prema njima, a s druge strane, u slučaju pristanka neće im se dodijeliti nikakva novčana naknada. Također im je naglašeno da će pri tome njihov identitet biti u potpunosti zaštićen i da se njihovo ime nigdje neće pojavljivati te da se rezultati ovog rada neće upotrebljavati u profitne svrhe. Sudionicima koji su pristali sudjelo- 
vati u istraživanju dan je upitnik, uz napomenu da bi odgovori trebali ukazivati na ono što je za sudionika najtočnije, a ne ono što bi, po njihovu mišljenju, bilo točno za većinu ljudi. Ostavljena im je mogućnost uvida u rezultate po završetku cijelog istraživanja te im se ljubazno zahvalilo na suradnji.

\section{Rezultati}

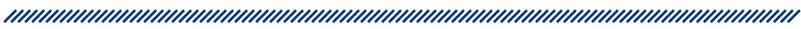

Tablica 1 prikazuje aritmetičku sredinu, standardnu devijaciju i raspon rezultata skala primijenjenih u ovom istraživanju. Dob i osnovni statistički pokazatelji povezani s tjelesnim karakteristikama prikazani su odvojeno za studentice i studente, jer bi bilo neopravdano računati prosječnu visinu i težinu na ukupnom uzorku s obzirom na to da se muškarci i žene u tim mjerama znatno razlikuju. Samoprocjena zdravlja studenata relativno je visoka $(M=4,18, S D=0,65)$, dok je zadovoljstvo učestalošću bavljenja tjelesnom aktivnošću prosječno ( $M=2,99, S D=1)$. Što se stupnja tjelesne aktivnosti tiče, indeks ukupne tjelesne aktivnosti iznosi $8,36(S D=1,19)$, dok je s obzirom na različite oblike tjelesne aktivnosti najviši indeks aktivnosti slobodnog vremena $(M=3,32, S D=0,64)$, sli- jedi indeks sportske aktivnosti $(M=2,71, S D=0,65)$ te indeks nastavne aktivnosti $(M=2,33, S D=0,58)$. Što se tiče osobina ličnosti, studenti nisu zabilježili previsok stupanj sramežljivosti $(M=2,26, S D=0,57)$, dok njihovo prosječno samopoštovanje iznosi 3,31 (SD =0,42). Na dimenzijama ličnosti mjerenima upitnikom EPQ najviši rezultat studenti su zabilježili na dimenziji ekstroverzije ( $M=15,13$, $\mathrm{SD}=3,78)$, a slijedi neuroticizam $(\mathrm{M}=9,90, \mathrm{SD}=5,14)$. $\mathrm{Na}$ skali laži studenti su iskazali relativno nizak prosječan rezultat $(M=7,82, S D=3,73)$.

Rezultati prikazani u tablici 2 ukazuju na to da, iako studenti imaju viši indeks ukupne tjelesne aktivnosti $(M=8,50, S D=1,25)$ od studentica $(M=8,33, S D=1,17)$, nema statistički značajne spolne razlike. No statistički značajna spolna razlika postoji s obzirom na indeks nastavne aktivnosti, pri čemu je kod studentica ( $M=2,37$, $\mathrm{SD}=0,58)$ značajno viši $(\mathrm{t}=-2,83, \mathrm{p}<0,01)$ nego kod studenta $(M=2,15, S D=0,58)$. $S$ druge strane, indeks sportske aktivnosti statistički je značajno viši ( $t=4,02$, $\mathrm{p}<0,01)$ kod studenata $(\mathrm{M}=2,97, \mathrm{SD}=0,70)$ nego kod studentica ( $M=2,64, S D=0,62)$. Također, pokazalo se da nema statistički značajne razlike u indeksu aktivnosti slobodnog vremena između studenata i studentica. Treba napomenuti da je razina značajnosti svih izvršenih t-testova $u$ istraživanju bila $p<0,01$, kako bi se izbjeglo moguću pogrešku zaključka uslijed provođenja višestrukih t-testova.

\begin{tabular}{|c|c|c|c|c|c|c|c|c|}
\hline \multirow[b]{2}{*}{ Spol } & \multicolumn{2}{|c|}{ M } & \multicolumn{2}{|c|}{ SD } & \multicolumn{2}{|c|}{ Minimum } & \multicolumn{2}{|c|}{ Maksimum } \\
\hline & $M(N=75)$ & $\check{Z}(\mathrm{~N}=266)$ & M & Ž & M & Ž & M & Ž \\
\hline Dob & 20,76 & 20,62 & 3,38 & 1,52 & 19 & 18 & 48 & 35 \\
\hline Visina (m) & 1,82 & 1,68 & 0,05 & 0,05 & 1,71 & 1,55 & 1,99 & 1,82 \\
\hline Težina (kg) & 80,75 & 62,2 & 12,07 & 9,15 & 56 & 45 & 125 & 97 \\
\hline Indeks tjelesne težine (BMI) & 24,13 & 21,93 & 3,31 & 2,95 & 17,09 & 16,65 & 32,79 & 37 \\
\hline Samoprocjena zdravlja & \multicolumn{2}{|c|}{4,18} & \multicolumn{2}{|c|}{0,65} & \multicolumn{2}{|c|}{1} & \multicolumn{2}{|c|}{5} \\
\hline Zadovoljstvo učestalošću bavljenja tjel. aktivnošću & \multicolumn{2}{|c|}{2,99} & \multicolumn{2}{|c|}{1} & \multicolumn{2}{|c|}{1} & \multicolumn{2}{|c|}{5} \\
\hline Indeks nastavne aktivnosti & \multicolumn{2}{|c|}{2,33} & \multicolumn{2}{|c|}{0,58} & \multicolumn{2}{|c|}{1,14} & \multicolumn{2}{|c|}{4} \\
\hline Indeks sportske aktivnosti & \multicolumn{2}{|c|}{2,71} & \multicolumn{2}{|c|}{0,65} & \multicolumn{2}{|c|}{1,25} & \multicolumn{2}{|c|}{5} \\
\hline Indeks aktivnosti slobodnog vremena & \multicolumn{2}{|c|}{3,32} & \multicolumn{2}{|c|}{0,64} & \multicolumn{2}{|c|}{1,5} & \multicolumn{2}{|c|}{5} \\
\hline Indeks ukupne tjelesne aktivnosti & \multicolumn{2}{|c|}{8,36} & \multicolumn{2}{|c|}{1,19} & \multicolumn{2}{|c|}{5,07} & \multicolumn{2}{|c|}{12,64} \\
\hline Sramežljivost & \multicolumn{2}{|c|}{2,26} & \multicolumn{2}{|c|}{0,57} & \multicolumn{2}{|c|}{1} & \multicolumn{2}{|c|}{4} \\
\hline Samopoštovanje & \multicolumn{2}{|c|}{3,31} & \multicolumn{2}{|c|}{0,42} & \multicolumn{2}{|c|}{1,9} & & 4 \\
\hline Ekstroverzija & & 13 & & & & 1 & & 1 \\
\hline Neuroticizam & & & & & & 0 & & 2 \\
\hline Skala laži & & & & & & 0 & & 8 \\
\hline
\end{tabular}


Tablica 2. Razlike u indeksu nastavne aktivnosti, sportske aktivnosti i aktivnosti slobodnog vremena s obzirom na spol sudionika

\begin{tabular}{|c|c|c|c|c|c|}
\hline Skala & Spol & $\mathrm{N}$ & M & SD & $\mathrm{t}$ \\
\hline \multirow{2}{*}{ Indeks nastavne aktivnosti } & muški & 75 & 2,15 & 0,56 & \multirow{2}{*}{$-2,83$} \\
\hline & ženski & 264 & 2,37 & 0,58 & \\
\hline \multirow{2}{*}{ Indeks sportske aktivnosti } & muški & 75 & 2,97 & 0,70 & \multirow{2}{*}{4,02} \\
\hline & ženski & 264 & 2,64 & 0,62 & \\
\hline \multirow{2}{*}{ Indeks aktivnosti slobodnog vremena } & muški & 75 & 3,36 & 0,63 & \multirow{2}{*}{0,56} \\
\hline & ženski & 264 & 3,31 & 0,64 & \\
\hline \multirow{2}{*}{ Indeks ukupne tjelesne aktivnosti } & muški & 75 & 8,5 & 1,25 & \multirow{2}{*}{1,09} \\
\hline & ženski & 264 & 8,33 & 1,17 & \\
\hline \multicolumn{6}{|c|}{$p<0,01$} \\
\hline
\end{tabular}

Iz tablice 3 vidljivo je da su koeficijenti korelacije između indeksa ukupne tjelesne aktivnosti te indeksa nastavne aktivnosti $(r=0,496, p<0,01)$, indeksa sportske aktivnosti $(r=0,662, p<0,01)$ i indeksa aktivnosti slobodnog vremena $(r=0,729, p<0,01)$ visoki i statistički značajni, što je očekivano i razumljivo. Što se tiče povezanosti tjelesne aktivnosti i osobina ličnosti, ukupna je tjelesna aktivnost statistički značajno negativno povezana sa sramežljivošću $(r=-0,177, p<0,01)$ i statistički značajno pozitivno povezana s ekstroverzijom $(r=0,252, p<0,01)$, iako su korelacije vrlo niske, dok nema statistički značajne povezanosti sa samopoštovanjem $(r=0,059, p>0,05)$ i neuroticizmom $(r=-0,037$, $p>0,05)$. Indeks nastavne aktivnosti statistički je značajno negativno povezan sa samopoštovanjem $(r=-0,172, p<0,01)$ i statistički značajno pozitivno $s$ neuroticizmom ( $r=0,157, p<0,01)$, dok nema statistički značajne povezanosti s ostalim osobinama ličnosti mjerenima u istraživanju. Također, treba napomenuti da indeks nastavne aktivnosti nije statistički značajno povezan ni $s$ indeksom sportske aktivnosti $(r=-0,075$, $p>0,05)$ ni s indeksom aktivnosti slobodnog vremena $(r=0,081, p>0,05)$. Indeks sportske aktivnosti statistički je značajno pozitivno povezan sa samopoštovanjem $(r=0,164, p<0,01)$ i ekstroverzijom $(r=0,211, p<0,01)$, a negativno sa sramežljivošću $(r=-0,183, p<0,01)$, dok nema statistički značajne povezanosti $s$ neuroticizmom. Na kraju, indeks aktivnosti slobodnog vremena

\begin{tabular}{|c|c|c|c|c|c|c|c|c|}
\hline & 1. & 2. & 3. & 4. & 5. & 6. & 7. & 8. \\
\hline 1. Indeks nastavne aktivnosti & 1 & $-0,075$ & 0,081 & 0,469 & 0,064 & $-0,172$ & 0,073 & 0,157 \\
\hline 2. Indeks sportske aktivnosti & & 1 & 0,276 & 0,662 & $-0,183$ & 0,164 & 0,211 & $-0,091$ \\
\hline 3. Indeks aktivnosti slobodnog vremena & & & 1 & 0,729 & $-0,199$ & 0,102 & 0,187 & $-0,121$ \\
\hline 4. Indeks ukupne aktivnosti & & & & 1 & $-0,177$ & 0,059 & 0,252 & $-0,037$ \\
\hline 5. Sramežljivost & & & & & 1 & $-0,449$ & $-0,584$ & 0,322 \\
\hline 6. Samopoštovanje & & & & & & 1 & 0,344 & $-0,428$ \\
\hline 7. Ekstroverzija & & & & & & & 1 & $-0,271$ \\
\hline 8. Neuroticizam & & & & & & & & 1 \\
\hline \multicolumn{9}{|c|}{$\begin{array}{l}p<0,05 \\
p<0,01\end{array}$} \\
\hline
\end{tabular}


statistički je značajno pozitivno povezan s ekstroverzijom ( $r=0,187, p<0,01)$, a negativno sa sramežljivošću $(r=-0,199, p<0,01)$ i neuroticizmom $(r=-0,121$, $\mathrm{p}<0,05)$, dok nema statistički značajne povezanosti s ostalim osobinama ličnosti. Treba naglasiti da su sve korelacije između različitih indeksa tjelesne aktivnosti i osobina ličnosti, čak i one značajne, vrlo niske.

Kako bismo utvrdili prediktorsku vrijednost promatranih osobina ličnosti, proveli smo regresijsku analizu. Kao što se može vidjeti iz tablice 4, ukupno je s pomoću prediktorskih varijabli (sramežljivost, samopoštovanje, ekstroverzija i neuroticizam) objašnjeno 6,7 \% kriterijske varijable Ukupna tjelesna aktivnost $(R=0,259$; $\left.R^{2}=0,067 ; F(4,327)=5,87 ; p<0,01\right)$. Na temelju beta koeficijenta vidljivo je da je jedini značajni prediktor tjelesne aktivnosti ekstroverzija $(\beta=0,241 ; p<0,01)$.

Iz tablice 5, nakon što smo sudionike istraživanja po medijanu podijelili na one $s$ nižim i višim indeksom

\begin{tabular}{|c|c|c|}
\hline \multicolumn{3}{|c|}{ Tablica 4. Prognoza varijable. } \\
Ukupna tjelesna aktivnost na temelju \\
sramežljivosti, samopoštovanja, \\
ekstroverzije i neuroticizma \\
\hline Prediktori & Beta & t-test \\
\hline Sramežljivost & $-0,055$ & $-0,779$ \\
\hline Samopoštovanje & $-0,032$ & $-0,502$ \\
\hline Ekstroverzija & 0,241 & $\mathbf{3 , 6 2 2}$ \\
\hline Neuroticizam & 0,035 & 0,583 \\
\hline Kriterij - Ukupna tjelesna & $\mathrm{R}=0,259 ; \mathrm{R}^{2}=0,067$ \\
\hline aktivnost & $\mathrm{F}(\mathbf{4}, \mathbf{3 2 7})=5,87 ; \mathrm{p}<0,01$ \\
\hline
\end{tabular}

ukupne tjelesne aktivnosti, možemo zaključiti da se studenti statistički značajno razlikuju samo u stupnju sramežljivosti $(t=3,6, p<0,01)$ i ekstroverzije ( $t=-3,83, p<0,01)$, pri čemu su oni s nižim indeksom ukupne tjelesne aktivnosti sramežljiviji $(M=2,33$, $\mathrm{SD}=0,56)$ i manje ekstrovertirani $(M=14,60, \mathrm{SD}=3,86)$ od onih s višim (sramežljivost $-M=2,09, S D=0,56$; ekstroverzija $M=16,27, S D=3,34)$. Nema statistički značajne razlike u samopoštovanju i neuroticizmu.

Ako se promatraju razlike u osobinama ličnosti samo s obzirom na visinu indeksa sportske aktivnosti (tablica 6 ), sve su statistički neznačajne ekstroverzije ( $t=-3,6$, $p<0,01$ ), gdje su sportski aktivniji ujedno i ekstrovertiraniji $(M=15,92, S D=3,45)$ od onih koji su manje aktivni $(M=14,46, S D=3,92)$.

Tablica 7 pokazuje nam razlike u osobinama ličnosti s obzirom na indeks aktivnosti slobodnog vremena te je vidljivo da su te razlike statistički značajne na dimenziji sramežljivosti $(t=3,76, p<0,01)$ i ekstroverzije $(t=-3,93, p<0,01)$. Pri tome su oni koji su manje aktivni u slobodno vrijeme (ne računajući sport) sramežljiviji $(M=2,36, S D=0,58)$ od onih koji su aktivniji $(M=2,13$, $S D=0,54)$ te su, $u$ odnosu na aktivnije $(M=15,99$, $S D=3,22)$, introvertiraniji $(M=14,40, S D=4,06)$. Nije dobivena statistički značajna razlika na dimenzijama samopoštovanja i neuroticizma.

\begin{tabular}{|c|c|c|c|c|c|}
\hline Skala & Indeks ukupne tjelesne aktivnosti & $\mathrm{N}$ & M & SD & $\mathrm{t}$ \\
\hline \multirow{2}{*}{ Sramežljivost } & niži & 233 & 2,33 & 0,56 & \multirow{2}{*}{3,6} \\
\hline & viši & 107 & 2,09 & 0,56 & \\
\hline \multirow{2}{*}{ Samopoštovanje } & niži & 232 & 3,29 & 0,42 & \multirow{2}{*}{$-0,73$} \\
\hline & viši & 106 & 3,33 & 0,42 & \\
\hline \multirow{2}{*}{ Ekstroverzija } & niži & 232 & 14,60 & 3,86 & \multirow{2}{*}{$-3,83$} \\
\hline & viši & 106 & 16,27 & 3,34 & \\
\hline \multirow{2}{*}{ Neuroticizam } & niži & 232 & 9,87 & 5,21 & \multirow{2}{*}{$-0,13$} \\
\hline & viši & 106 & 9,95 & 5,01 & \\
\hline \multicolumn{6}{|c|}{$p<0,01$} \\
\hline
\end{tabular}




\begin{tabular}{|c|c|c|c|c|c|}
\hline Skala & Indeks sportske aktivnosti & $\overline{\mathrm{N}}$ & $\bar{M}$ & SD & $\bar{t}$ \\
\hline \multirow{2}{*}{ Sramežljivost } & niži & 185 & 2,33 & 0,58 & \multirow{2}{*}{2,44} \\
\hline & viši & 154 & 2,17 & 0,55 & \\
\hline \multirow{2}{*}{ Samopoštovanje } & niži & 184 & 3,26 & 0,42 & \multirow{2}{*}{$-2,39$} \\
\hline & viši & 155 & 3,37 & 0,41 & \\
\hline \multirow{2}{*}{ Ekstroverzija } & niži & 183 & 14,46 & 3,92 & \multirow{2}{*}{$-3,6$} \\
\hline & viši & 155 & 15,92 & 3,45 & \\
\hline \multirow{2}{*}{ Neuroticizam } & niži & 185 & 10,28 & 5,24 & \multirow{2}{*}{1,49} \\
\hline & viši & 153 & 9,44 & 5,00 & \\
\hline \multicolumn{6}{|c|}{$p<0,01$} \\
\hline
\end{tabular}

\begin{tabular}{|c|c|c|c|c|c|}
\hline Skala & Indeks aktivnosti slobodnog vremena & $\mathrm{N}$ & M & SD & t \\
\hline \multirow{2}{*}{ Sramežljivost } & niži & 184 & 2,36 & 0,58 & \multirow{2}{*}{3,76} \\
\hline & viši & 155 & 2,13 & 0,54 & \\
\hline \multirow{2}{*}{ Samopoštovanje } & niži & 186 & 3,27 & 0,43 & \multirow{2}{*}{$-2,05$} \\
\hline & viši & 153 & 3,36 & 0,41 & \\
\hline \multirow{2}{*}{ Ekstroverzija } & niži & 182 & 14,40 & 4,06 & \multirow{2}{*}{$-3,93$} \\
\hline & viši & 156 & 15,99 & 3,22 & \\
\hline \multirow{2}{*}{ Neuroticizam } & niži & 182 & 10,38 & 4,98 & \multirow{2}{*}{1,89} \\
\hline & viši & 156 & 9,33 & 5,28 & \\
\hline \multicolumn{6}{|c|}{$p<0,01$} \\
\hline
\end{tabular}

\section{Diskusija}

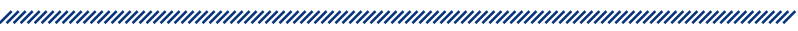

Iz dobivenih je rezultata (tablica 1 ) jasno da je samoprocjena zdravlja izrazito visoka, no to je i očekivano s obzirom na to da je riječ o populaciji studenata. Budući da studenti svoje zdravlje procjenjuju izrazito dobrim, čini se opravdanim pretpostaviti da ova varijabla nije moderator/medijator odnosa između TA $\mathrm{i}$ ispitanih varijabli (loše bi tjelesno zdravlje npr. moglo ograničavati bavljenje tjelesnom aktivnošću ili bi recimo moglo utjecati na samopoštovanje). BMI je u granicama normalne težine $i$ odgovara onima koji su dobili Rogulj i sur. ${ }^{25}$ na studentskoj populaciji u Splitu. gdje je prosječni indeks tjelesne mase studentica iznosio 21,86 , a studenata 23,79 , što je statistički značajno različito, ali i očekivano zbog većeg udjela mišićne mase kod studenata. Ako promotrimo rezultate prikazane u tablici 1 , možemo zaključiti su studenti najmanje aktivni u sklopu nastave, što ne treba čuditi, jer studenti prvenstveno nastavom smatraju predavanja u sklopu kojih uglavnom nisu tjelesno aktivni. No očekivao se viši indeks nastavne aktivnosti s obzirom na to da studenti Zdravstvenog veleučilišta u sklopu nastave odlaze u brojne bolnice, domove zdravlja, domove za starije i nemoćne te druge institucije povezane sa skrbi o građanima, a u sklopu čega je sigurno povećana i njihova tjelesna aktivnost. Još niži indeks nastavne aktivnosti zabilježili su i Matković i sur. ${ }^{21}$ u svojem istraživanju provedenom na studentima Medicinskog fakulteta u Zagrebu, što ukazuje na to da studenti nastavu ne percipiraju kao tjelesno zahtjevnu. I indeksi sportske aktivnosti odnosno aktivnosti slobodnog vremena viši su nego u ranije spomenutom istraživanju Matković i sur. ${ }^{20}$, što ukazuje na to da su studenti Zdravstvenog veleučilišta ipak donekle tjelesno aktivniji nego njihove kolege s Medicinskog 
fakulteta. Jurakić i sur. ${ }^{26}$ proveli su istraživanje kako bi utvrdili stupanj tjelesne aktivnosti hrvatske populacije u različitim područjima svakodnevnog života te je, među ostalim, najmanji stupanj tjelesne aktivnosti zabilježen kod adolescentske i mlađe odrasle dobi. Andrijašević i sur. ${ }^{27}$ su pak proveli istraživanje kako bi se utvrdilo na koji način studenti Sveučilišta u Splitu provode svoje slobodno vrijeme i u kojoj su mjeri u njemu zastupljene sportske aktivnosti te kakva je njihova povezanost sa samoprocjenom zdravlja. Dobiveni rezultati bili su zabrinjavajući jer je većina navedenih smetnji proizišla iz nedovoljnog kretanja. Autori smatraju da bi strategija načina korištenja slobodnim vremenom mladih trebala biti predmetom istraživanja i interesa različitih društvenih struktura koje bi morale potaknuti društvo na akciju za poboljšanje kvalitete života studenata. Također, studenti su prosječno zadovoljni učestalošću bavljenja tjelesnom aktivnošću, što ukazuje na to su spremni napredovati u tom pogledu.

Viši stupanj tjelesne aktivnosti kod muškaraca (tablica 2) u skladu je s očekivanjima. Statistički značajno viši indeks nastavne aktivnosti iznenađuje s obzirom na to da je nastavno opterećenje jednako za oba spola. Matković i sur. ${ }^{21}$, analizirajući razlike između studentica i studenata, zaključili su da jednako doživljavaju opterećenje na nastavi, što je očekivano jer, naravno, nema razlika u zahtjevima koje bi se mogle povezati sa spolom. No na temelju rezultata ovog istraživanja može se zaključiti kako je očito da se studentice Zdravstvenog veleučilišta teže nose sa zahtjevima koje im studij nameće te i tjelesnu aktivnost na njemu procjenjuju višom. Razlike na indeksu sportske aktivnosti u korist muškaraca u skladu su s rezultatima prijašnjih istraživanja. Takvu su razliku dobili i Matković i sur. ${ }^{21}$ te Mišigoj-Duraković i sur. ${ }^{27}$, čiji rezultati istraživanja pokazuju da žene imaju niži indeks sportske aktivnosti. Nekoliko je istraživanja pokušalo objasniti zabilježene spolne razlike u stupnju tjelesne aktivnosti. Chung i Phillips (2002; prema Strauss i sur. ${ }^{14}$ ) naglašavaju da muškarci u prosjeku imaju pozitivnije stavove prema vježbanju te su prema tome skloniji prakticirati određeni oblik tjelesne aktivnosti u svoje slobodno vrijeme. Treasure, Lox i Lawton ${ }^{29}$ pak tvrde da bi društveni aspekt vježbanja mogao utjecati na bavljenje tjelesnom aktivnošću kod žena. lako nema statistički značajne spolne razlike u indeksu ukupne tjelesne aktivnosti, jasno je da su muškarci tjelesno aktivniji te bi trebalo dodatno raditi na približavanju raznih oblika tjelesne aktivnosti ženskoj populaciji.

Regresijskom analizom (tablica 4) potvrđeno je da je na temelju promatranih psiholoških varijabli moguće statistički značajno predvidjeti stupanj tjelesne aktivnosti, no udio je objašnjene varijance nizak, što je u skladu s dosadašnjim istraživanjima o povezanosti tjelesne aktivnosti i ličnosti ${ }^{16}$. Također, kao jedini značajni prediktor pokazala se ekstroverzija, koja se i u dosadašnjim istraživanjima pokazala kao najpouzdaniji prediktor tjelesne aktivnosti ${ }^{16}$. I iz matrice korelacija (tablica 3) vidi se da je ekstroverzija statistički značajno povezana s tjelesnom aktivnošću, kao i na temelju t-testova iz kojih se vidi da su tjelesno aktivniji ujedno i ekstrovertiraniji (tablice 5, 6 i 7), što je u skladu s našim očekivanjima. Lochbaum, Bixby i Wang ${ }^{20}$ proveli su istraživanje u kojem su došli do toga da pojedinci manje motivirani za vježbanje, tj. oni koji se manje bave tjelesnom aktivnošću, ujedno postižu i niže rezultate na dimenzijama ekstroverzije i savjesnosti. Pozitivnu su povezanost ekstroverzije i tjelesne aktivnosti u svojim istraživanjima, među ostalima, dobili i Kirkcaldy i Furnham ${ }^{17}$ te Rhodes i Smith ${ }^{16}$. Očito introvertiranima toliko ne odgovara okolina s mnogo podražaja ili situacija koja izaziva uzbuđenje te bi takvim pojedincima još u djetinjstvu trebalo sugerirati aktivnost koja odgovara njihovoj ličnosti.

Kao što se može vidjeti iz tablice 3, sramežljivost je statistički značajno negativno povezana kako s indeksom ukupne tjelesne aktivnosti tako i s indeksima sportske aktivnosti i aktivnosti slobodnog vremena. Nema povezanosti jedino s indeksom nastavne aktivnosti, no to je logično jer je povezan prvenstveno sa studijskim programom pa niti ne može ovisiti ili utjecati na osobine ličnosti, osim ako odabir različitih studija Zdravstvenog veleučilišta ne ovisi o osobinama ličnosti, no to je tema za neki drugi rad. Iz tablica 5, 6. i 7. vidljivo je da i t-testovi pokazuju da se sramežljiviji pojedinci manje bave tjelesnim aktivnostima, što je u skladu s očekivanjima i postojećom literaturom. Page i Zarco ${ }^{11}$ navode da činjenica da su mladi ljudi koji se često bave tjelesnim aktivnostima manje sramežljivi od onih koji se ne bave ukazuje na socijalni aspekt tjelesnih aktivnosti kojima se najčešće bave. Tjelesne se aktivnosti adolescenata i studenata vrlo često odvijaju unutar socijalnih grupa poput razreda, studentskih grupa, momčadi ili grupa u okviru fitnes-centara. Vjerojatnije je da će u takvom okruženju sramežljiviji pojedinci biti inhibirani ili anksiozni te da će izbjegavati sudjelovanje u takvom vidu tjelesnih ili sportskih aktivnosti. Sljedeći je problem da sramežljiviji nemaju socijalne vještine razvijene u mjeri u kojoj to imaju nesramežljivi pojedinci te im se samim tim teže priključiti određenoj grupi ili se pak snaći i prilagoditi u njoj.

Rezultati ne pokazuju jasnu povezanost samopoštovanja i tjelesne aktivnosti (tablice 3, 4, 5, 6 i 7), iako je očita tendencija rasta samopoštovanja s rastom stupnja bavljenja tjelesnom aktivnošću. Geckil i Dundar ${ }^{30} \mathrm{u}$ istraživanju na preko tisuću turskih adolescenata došli su do rezultata da je samopoštovanje statistički značajno povezano sa zdrav- 
stvenim ponašanjem, pri čemu adolescenti s višim samopoštovanjem manje sudjeluju u zdravstveno rizičnim ponašanjima, a više u pozitivnim ponašanjima poput češće tjelesne aktivnosti. Istraživanje rađeno na adolescentima ${ }^{31}$ pokazalo je da je samopercepcija pozitivno povezana s tjelesnom aktivnošću te da utječe na povećanje i socijalne i atletske samopercepcije bez obzira na spol. Koncept selfa složen je i višedimenzionalan. Promjene u stupnju bavljenja tjelesnom aktivnošću ne djeluju jednako na sve aspekte samopercepcije i percipirane bi kompetencije mogle pomoći objasniti zašto ta povezanost nije dobivena u svim istraživanjima, pogotovo u onima u kojima se ispitivalo samopoštovanje kao jedinstveni konstrukt. Pretpostavlja se da, od mnogih čimbenika koji utječu na samopoštovanje, najveći utjecaj na pojedinca imaju oni koji su mu najvažniji. Tako tjelesna aktivnost ne mora značajno utjecati na samopoštovanje pojedincima kojima fizička spremnost nije važna, pogotovo adolescentima i studentima koji su usmjereni na akademski razvoj i uspjeh.

Dosadašnjim se istraživanjima pokazalo da je neuroticizam negativno povezan s tjelesnom aktivnošć $u^{32}$. Očito je da anksioznijim i emocionalno nestabilnijim osobama tjelesna aktivnost ne odgovara u mjeri u kojoj odgovara emocionalno stabilnim osobama te vjerojatno ne pobuđuje pozitivne emocije i osjećaj ugode nakon aktivnosti koja se bilježi u prosječnoj populaciji. Rezultati našeg istraživanja nisu potvrdili da se studenti razlikuju u stupnju neuroticizma s obzirom na stupanj bavljenja tjelesnom aktivnošću (tablice 4, 5, 6 i 7), iako su dobivene značajna negativna korelacija neuroticizma i nastavne aktivnosti te pozitivna $s$ indeksom aktivnosti slobodnog vremena. To bi moglo ukazivati na činjenicu da neurotičnije osobe percipiraju jednaku tjelesnu aktivnost kao intenzivniju od emocionalno stabilnijih osoba, pogotovo kada ta aktivnost nije posljedica vlastitog izbora i može pobuđivati negativne emocije (nastavna aktivnost) te su se očito manje skloni baviti određenim aktivnostima u slobodno vrijeme (hodanje, bicikl), što bi se trebalo dodatno istražiti istraživanjem usmjerenim specifično tom odnosu.

\section{Nedostatci istraživanja}

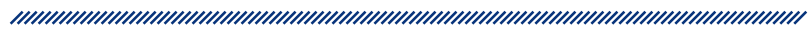

Kao najveći se nedostatak odmah nameće problem uzorka. Uzorak je bio prigodan te je, iako je bio zadovoljavajuće veličine, to sigurno utjecalo na smanjeni varijabilitet mjerenih pojava. Studenti su specifična populacija čija se tjelesna aktivnost sigurno razlikuje od one opće populacije, a moguće je da je i činjenica da je riječ o budućim visokoobrazovanim ljudima utjecala na rezultate na dimenzijama ličnosti ${ }^{33}$. No i ovakav prigodni uzorak ima prednosti jer nam daje uvid u razinu tjelesne aktivnosti budućih zdravstvenih djelatnika, za koje se očekuje da će u većoj mjeri razumjeti i poštovati načela zdravog načina života od osoba iz opće populacije.

Nadalje, i prijašnja su istraživanja dobila niske korelacije između tjelesne aktivnosti $\mathrm{i}$ ispitivanih osobina ličnosti, kao i koeficijente determinacije, gdje je postotak objašnjene varijance kriterija varirao između $3 \%$ i $8 \%{ }^{15}$, što očito ukazuje na to da je ta povezanost složena i ovisi o mnogim drugim faktorima, što bi trebalo uzeti u obzir u budućim istraživanjima. Korelacijski nacrt omogućava utvrđivanje povezanosti između pojava, no nemoguće je na temelju toga odrediti uzročno-posljedični odnos. lako je nedvojbena povezanost osobina ličnosti i tjelesne aktivnosti, potrebna su dodatna istraživanja u tom pravcu koja će se bazirati na dodatnim multivarijantnim analizama, longitudinalnim nacrtima, različitim programima tjelesne aktivnosti ovisnima o osobinama ličnosti sudionika te objektivnoj mjeri tjelesne aktivnosti, kao i sa zasebnim uzorcima mladića i djevojaka.

\section{Zaključak}

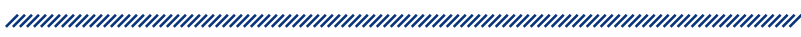

Studenti Zdravstvenog veleučilišta zabilježili su prosječan stupanj bavljenja tjelesnom aktivnošću te bi se dodatnom analizom trebali odrediti glavni razlozi nedovoljnog bavljenja tjelesnom aktivnošću kako bi se budući programi i intervencije za njezino povećanje u studentskoj populaciji mogli specifično usmjeriti na konkretne probleme.

Studenti se značajno više bave tjelesnom aktivnošću u slobodno vrijeme (bilo sportskim bilo nesportskim aktivnostima) od studentica, no studentice značajno višim percipiraju stupanj tjelesne aktivnosti na nastavi nego što to čine njihovi muški kolege.

Što se tiče povezanosti osobina ličnosti i tjelesne aktivnosti, jedine su jasno zabilježene povezanosti s tjelesnom aktivnošću pozitivna s ekstroverzijom te negativna sa sramežljivošću. Slični su rezultati dobiveni testiranjem razlike između studenata s obzirom na indeks ukupne tjelesne aktivnosti, kojim je dobiveno da su aktivniji ekstrovertiraniji, manje sramežljivi, dok razlike s obzirom na indeks sportske aktivnosti i aktivnosti u slobodno vrijeme ukazuju na to da aktivniji imaju i viši stupanj samopoštovanja. 


\section{Literatura}

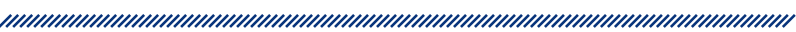

1. Taylor CB, Sallis JF, Needle R. The relation of physical activity and exercise to mental health. Public Health Reports. 1985;100(2):195-202.

2. Matković A, Nedić A, Meštrov M, Ivković J. Uobičajena tjelesna aktivnost studenata medicinskog fakulteta sveučilišta u Zagrebu. Hrvatski Športsko medicinski Vjesnik. 2010;25:87-91.

3. Burgos-Garrido E, Gurpegui M, Jurado D. Personality traits and adherence to physical activity in patients attending a primary health centre. International Journal of Clinical and Health Psychology. 2011;11(3):539-547.

4. Bartoluci M, Škorić, S. Uloga menadžmenta u sportskoj rekreaciji. Zbornik radova 17. ljetne škole kineziologa Republike Hrvatske, 2008;464-469.

5. Cox R. Psihologija sporta: koncepti primjene. Jastrebarsko: Naklada Slap; 2005.

6. Butler SM, Black DR, Blue CL, Gretebeck RJ. Change in diet, physical activity, and body weight in female college freshman. American Journal of Health Behavior. 2004;28(1):24-32.

7. Huang TT, Harris KJ, Lee RE, Nazir N, Born W, Kaur H. Assessing overweight, obesity, diet, and physical activity in college students. Journal of American College Health. 2003;52(2):83-86.

8. Pedišić Ž. Tjelesna aktivnost $i$ njezina povezanost sa zdravljem i kvalitetom života u studentskoj populaciji. Zagreb: Kineziološki fakultet; 2011.

9. Zarevski P, Mamula M. Pobijedite sramežljivost. Jastrebarsko: Naklada Slap; 1998.

10. Carducci BJ, Zimbardo PG. Are you shy? - the problem of shyness. Psychology Today. 1995;34-40.

11. Page RM, Zarco EP. Shyness, physical activity, and sports team participation among Philippine high school students. Child Study Journal. 2001;31(3):193-204.

12. Burušić J. Psihologija ličnosti II (skripta uz teorijski dio). Zagreb: Hrvatski studiji; 2001.

13. Bungić M, Barić R. Tjelesno vježbanje i neki aspekti psihološkog zdravlja. Hrvatski Športsko-medicinski Vjesnik. 2009;24:64-75.

14. Strauss RS, Rodzilsky D, Burack G, Colin M. Psychosocial correlates of physical activity in healthy children. Archives of Pediatrics and Adolescent Medicine. 2001;5(8):897902.

15. Castillo I, Molina-Garcia J. Adiposidad corporal y bienestar psicológico: efectos de la actividad física en universitarios de Valencia, España. Rev Panam Salud Publica. 2009;26(4):334-340.

16. Rhodes RE, Smith NEI. Personality correlates of physical activity: a review and meta-analysis. British Journal of Sports Medicine. 2006;40:958-965.
17. Kirkcaldy B, Furnham A. Extraversion, neuroticism, psychoticism and recreational choice. Personality and Individual Differences. 1991;12(12):1325-1331.

18. Eysenck HJ, Eysenck BG. Priručnik za Eysenckov upitnik ličnosti (EPQ - djeca i odrasli). Jastrebarsko: Naklada Slap; 1994.

19. Burgess SS, Pargman D. Stimulus-seeking, extraversion, and neuroticism in regular, occasional and non-exercisers. Annual Meeting of North American Society for the Psychology of Sport and Physical Activity; 1977.

20. Lochbaum MR, Bixby WR, Wang JCK. Achievement goal profiles for self report physical activity participation: Differences in personality. Journal of Sports Behavior. 2007;30(4);471-489.

21. Matković A, Nedić A, Meštrov M, Ivković J. Uobičajena tjelesna aktivnost studenata medicinskog fakulteta sveučilišta u Zagrebu. Hrvatski Športsko-medicinski Vjesnik. 2010;25;87-91.

22. Sorić M. Povezanost antropometrijskih i kardiorespiratornih funkcionalnih obilježja s pokazateljima tjelesne aktivnosti adolescenata i odraslih - longitudinalno istraživanje. Doktorska disertacija. Zagreb: Sveučilište u Zagrebu; 2010.

23. Burušić J. Ispitivanje individualnih razlika u samoprezentacijskim stilovima. Zagreb: Filozofski fakultet; 1999.

24. Lacković-Grgin K. Samopoimanje mladih. Jastrebarsko: Naklada Slap; 1994.

25. Rogulj N, Kovačević Ž, Utrobičić I, Krstulović H, Jukić J. Indeks tjelesne mase različito kineziološko angažiranih studentica i studenata. Život i škola. 2011;25:100-107.

26. Jurakić D, Pedišić Ž, Andrijašević M. Physical activity of Croatian population: cross-sectional study using International Physical Activity Questionnaire. Croatian Medical Journal. 2009;50:165-173.

27. Andrijašević M, Paušić J, Bavčević T, Ciliga D. Participation in leisure activities and self-perception of health in the students of the University of Split. Kineziology. 2005;37(1):21-31.

28. Mišigoj-Duraković M, Heimer S, Matković BR, Ružić L, Prskalo I. Physical Activity of urban adult population: Questionnaire study. Croatian Medical Journal. 2000;41(4):428-432.

29. Treasure DC, Lox CL, Lawton BR. Determinants of physical activity in a sedentary obese population. Journal of Sport \& Exercise Psychology. 1998;20:218-224.

30. Geckil E, Dündar O. Turkish adolescent health risk behaviors and self-esteem. Social Behavior and Personality. 2011;39(2):229-238.

31. Stein CJ, Fisher L, Berkey C, Colditz GA. Adolescent physical activity and perceived competence: does change in activity level impact self-perception? The Journal of Adolescent Health. 2007;40(5):462e1-462.e8.

32. Ingledew DK, Markland D. The role of motives in exercise participation. Psychology and Health. 2008;23(7):807-828.

33. Chamorro-Premuzic T, Furnham A. Personality predicts academic performance: Evidence from two longitudinal university samples. Journal of Research in Personality. 2003;37:319-338. 


\section{IS PHYSICAL ACTIVITY OF THE STUDENTS AT THE UNIVERSITY OF APPLIED HEALTH SCIENCES RELATED TO THEIR PERSONALITY TRAITS?}

1 Janko Babić

1 Melita Rukavina

1 Morana Bilić

1 Department of Health Psychology, University of Applied Health Sciences, Zagreb

\section{Abstract}

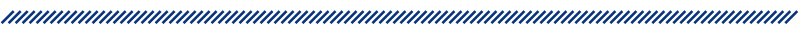

The aim of this study was to determine the level of physical activity of the students at the University of Applied Health Sciences and its association with personality traits (shyness, self-esteem, extraversion, neuroticism and psychoticism), and to establish gender differences in physical activity as well.

The data was collected from a group of 341 students (264 female, 77 male) at the University of Applied Health Sciences, with average age of 20,65. Physical activity was measured using the Baecke Questionnaire of Habitual Physical Activity (BQ), and personality traits were measured using the Cheek and Buss Shyness Scale (CBS), the Rosenberg Self - Esteem Scale (RSES), and the Eysenck Personality Questionnaire (EPQ).

The results showed that students are averagely physically active, and that male students are more active than their female colleagues. Furthermore, a significant positive correlation was established between the degree of physical activity and extraversion and selfesteem, while negative correlation was established between the degree of physical activity and shyness.
Further analysis should be conducted to examine the real structure of relationship between physical activity and personality traits, but, as these results also suggest, the relationship certainly exists and should be taken into consideration when creating new programs for promoting physical activity not only in student, but also in general population.

Keywords: physical activity, extraversion, shyness, self-esteem, neuroticism 



\section{Psihoedukacija o antipsihoticima u povećanju suradljivosti i efikasnosti liječenja}

1 Slađana Štrkalj Ivezić

2 Lana Mužinić

3 Marijo Vrdoljak

1 Klinika za psihijatriju Vrapče

2 Klinika za psihijatriju Klinička bolnica Dubrava

3 Dom za psihički bolesne osobe, Zagreb

\section{Sažetak}

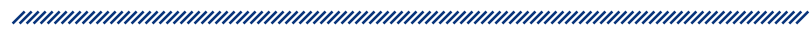

Rad prikazuje različite faktore koji utječu na suradljivost uzimanja antipsihotika s ciljem sveobuhvatnog sagledavanja suradljivosti u uzimanju lijekova osoba oboljelih od shizofrenije i drugih psihotičnih poremećaja. Pregled literature o suradljivosti pokazuje da su najkonzistentniji faktori povezani s nesuradljivošću nedostatak dobroga terapijskog odnosa s pacijentom i nedostatak uvida u postojanje bolesti, stoga bi vodeće strategije u postupanju sa suradljivošću trebale biti psihosocijalne. Premda su se mnogi pristupi, poput psihoedukacije i motivacijskog intervjuiranja, pokazali korisnima za povećanje suradljivosti, uključujući i terapiju suradljivosti, ne može se zaključiti da je bilo koji pristup bolji. Balansirani pristup psihološkim metodama koje uključuju elemente psihoedukacije, motivacijskog intervjuiranja, stvaranja odnosa povjerenja, aktivno uključenje u donošenje odluka o liječenju, orijentaciju prema osnaživanju i oporavku, točne informacije o bolesti i liječenju povezane s kontekstom osobnog života pacijenta i perspektivom oporavka te borbu protiv stigme i samostigmatizacije put je koji će pomoći da većina nesuradljivih bolesnika postane suradljiva i da suradljivi ostanu suradljivi.
Ključne riječi: psihoedukacija, suradljivost, antipsihotici

Datum primitka: 01.07.2015.

Datum prihvaćanja: 08.09.2015.

Adresa za dopisivanje:

Prof. dr. sc. Slađana Štrkalj Ivezić, dr. med

Klinika za psihijatriju Vrapče

Bolnička cesta 32, 10000 Zagreb, Hrvatska

Tel.: 0992273390

E-pošta: sladjana.strkalj-ivezic@zg.t-com.hr

\section{Uvod}

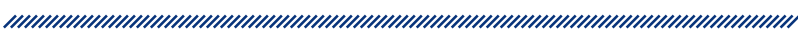

Psihofarmakološka terapija smatra se nezaobilaznom u liječenju osoba oboljelih od shizofrenije i drugih psihotičnih poremećaja. Liječenje antipsihoticima utječe na smanjenje težine simptoma ${ }^{1}$, povlačenje simptoma bolesti $^{2}$ te smanjivanje rizika za pojavu ponovne epizode bolesti, kao i potrebe za hospitalizacijom. Nesuradljivost u uzimanju lijekova povezana je s povećanim rizikom od ponovne pojave bolesti i hospitalizacije te suicidalnim pokušajima ${ }^{3}$. Posljedice nesuradljivosti dovode do negativnih socijalnih i ekonomskih utjecaja, kako za pacijenta, članove obitelji i službe za mentalno zdravlje tako i za društvo u cjelini ${ }^{4}$. Premda je efikasnost antipsihotika u liječenju oboljelih od shizofrenije i drugih psihotičnih poremećaja dokazana u brojnim istraživanjima ${ }^{5}$ te u kliničkoj praksi, odbijanje i prijevremeni 
prekid lijekova bez konzultacije s liječnicima česta je pojava i barijera učinkovitom liječenju ${ }^{6,7}$. Procjenjuje se da najmanje $50 \%{ }^{8-10}$, a prema jednom od najcitiranijih radova iz ovog područja i $58 \%{ }^{11}$ oboljelih osoba od psihotičnih poremećaja ne prihvaća terapiju ili je ne uzima kako je propisana. Stupanj nesuradljivosti raste tijekom vremena ${ }^{12}$, tako da se može očekivati da će oko $80 \%$ oboljelih od shizofrenije tijekom liječenja biti nesuradljivi ${ }^{13}$. lako je dosta poznato o uzrocima nesuradljivosti i terapijskim pristupima koji povećavaju suradljivost, još uvijek nema efikasnog rješenja za ovaj problem. Suprotno očekivanjima, noviji atipični antipsihotici nisu riješili problem suradljivosti ${ }^{14}$, tako da je danas naglasak na traženju učinkovitih metoda rješavanja problema nesuradljivosti na temelju individualnog pristupa.

\section{Što je suradljivost?}

Suradljivost se definira kao ponašanje pacijenta koje je u skladu s preporukama liječnika ${ }^{15}$, a kada je riječ o lijekovima, suradljivost je stupanj do kojeg se pacijent pridržava uzimanja lijekova prema preporukama liječnika koji je lijekove propisao. U stručnoj literaturi na engleskom jeziku susreću se tri termina koja označavaju suradljivost u uzimanju lijekova; compliance (hrv. pristajanje, udovoljavanje, pokoravanje) ${ }^{16}$, adherence (prianjanje, pristajanje, slijeđenje) ${ }^{16}$ i concordance (suglasnost, podudaranje) ${ }^{16}$. lako se sva tri termina označavaju kao suradljivost, nisu sinonimi, nego riječi sličnog značenja. U novije se vrijeme upotrebljava engleski izraz adherence kao najšire prihvaćen. Do promjene je došlo zbog različitog značenja navedenih riječi u engleskom jeziku. Izraz adherence (engl.) široko je prihvaćen u duhu partnerskog odnosa s pacijentom da bi se označilo aktivno sudjelovanje oboljelog u liječenju, gdje je uzimanje lijekova izbor pacijenta, čemu se teži u suvremenoj psihijatriji, u odnosu na compliance (engl.), koji više označava poslušnost, paternalistički odnos s pacijentom. Suvremena psihijatrija nastoji ograničiti paternalizam u pristupu samo onim pacijentima kod kojih je to u njihovu interesu, npr. pacijenti koji zbog bolesti imaju poteškoća da donesu odluku, a to je manji broj pacijenata, za razliku od većine pacijenata s kojima je potrebno uspostaviti dogovor o liječenju koji mora biti rezultat zajedničke odluke pacijenta i liječnika. Ima i mišljenja da postoji razlika između termina adherence i concordance na način da su to dva različita termina u kojem se adhe- rence odnosi na ponašanje, a concordance na proces konzultacije između pacijenta i liječnika u kojem se liječnik i pacijent slažu o izboru liječenja ${ }^{17}$. Postoji slaganje o tome da odluka o liječenju mora biti donesena u dogovoru s pacijentom nakon informiranog pristanka, kada pacijent dobije dovoljno informacija na temelju kojih bi trebao donijeti odluku, a one uključuju informacije o korisnosti liječenja i posljedicama koje bi eventualno mogle nastupiti.

\section{Uzroci nesuradljivosti}

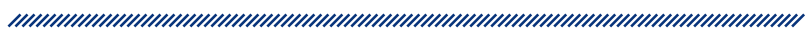

Brojni se faktori povezuju s nesuradljivošću u uzimanju lijekova ${ }^{3,18,19}$. Mnogi pacijenti namjerno prekidaju liječenje kao dio vlastite odluke. To se odnosi na one koji aktualno nemaju simptoma bolesti, bolje se osjećaju, žele se sami liječiti, nemaju povjerenja u liječnika i nemaju dovoljno medicinskih informacija ${ }^{20}$. Premda su izbor lijeka, njegova učinkovitost i nuspojave važni za suradljivost u liječenju, to nisu vodeći faktori koji utječu na suradljivost. Prednjače psihološki faktori, od kojih se terapijski odnos pokazao najboljim prediktorom suradljivosti, zatim slijede uvid i vjerovanja o bolesti i liječenju, a tek nakon njih drugi faktori poput nuspojava lijeka.

\section{Uvid u bolest, vjerovanja o bolesti i korist od liječenja}

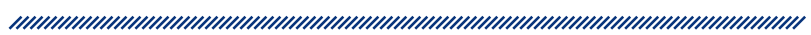

Poznato je da veliki broj oboljelih od shizofrenije negira da su bolesni i da im je liječenje potrebno. Negiranje bolesti ili nedostatak uvida te neintegracija bolesti i liječenja u život često su glavni razlozi nesuradljivosti. Brojni razlozi pridonose negiranju bolesti, a povezani su s različitim faktorima ličnosti, odnosom sa službama liječenja i neadekvatnim i/ili nedovoljnim informacijama o bolesti i liječenju. Poboljšanje odnosa s terapeutima, psihološki postupci i informiranje pacijenata sigurno bi mogli pomoći da se poveća razumijevanje i prihvaćanje bolesti. Mnogi pacijenti nisu informirani o svojoj bolesti i liječenju, npr. mnogi ne znaju zašto uzimaju lijekove ${ }^{21}$. Pacijentovo je razumijevanje vlastitog stanja u pozi- 
tivnoj korelaciji sa suradljivošću. Tako će pacijenti koji razumiju zašto moraju uzimati lijek biti više suradljivi ${ }^{22}$. Stoga bi adekvatne informacije o bolesti mogle nekim pacijentima pomoći da postanu ili ostanu suradljivi.

Uviđanje koristi od liječenja uvelike ovisi o uvidu pacijenta da postoji bolest. Smatra se da je uvid u bolest jedan od najčešćih prediktora suradljivosti u liječenju ${ }^{18,23}$. Vjerovanja o zdravlju važna su za suradljivost i važno je da pacijent vjeruje u korisnost liječenja ${ }^{24}$. Vjerovanja da će lijek izazvati ovisnost negativno djeluju na suradljivost ${ }^{25}$. Vjerovanja pacijenta i vjerovanja liječnika o zdravlju i bolesti mogu biti posve različita te to treba uzeti u obzir. Vjerovanje u korisnost antipsihotika dosta ovisi o informacijama o bolesti koje pacijent ima i vjerovanju o utjecaju liječenja na simptome njegove bolesti ${ }^{23}$. Nažalost, mnogi pacijenti napuštaju bolnicu a da im nije jasno zbog čega moraju uzimati lijekove, mnogi krivo razumiju kako bi trebali uzimati lijek, npr. po potrebi ${ }^{26}$. Uvid u bolest povezan je sa stavovima o zdravlju i bolesti te s informacijama o bolesti. Očekuje se da bi povećanje uvida moglo dovesti do bolje suradljivosti, stoga treba razmisliti o informacijama o bolesti i o stavovima koje bolesnik ima prema bolesti, koji se mogu značajno razlikovati od stavova liječnika. Rad u cilju povećanja uvida mora biti vrlo pažljiv, važno je znati da je stjecanje uvida postupan psihološki proces na kojem je potrebno raditi. Prednost treba dati postizanju odnosa povjerenja prije nego što se počne raditi na uvidu. Potreban je oprez, jer je riječ o psihološki osjetljivom procesu u kojem pacijent postupno mijenja svoje stavove, a ima i svoje reakcije za koje je potrebno vrijeme da se obrade. Kod jednog broja pacijenata liječnik mora biti spreman na to da može doći do pojave depresije kod pacijenta nakon stjecanja uvida ${ }^{27}$. Informacije o bolesti moraju se uvijek dati u kontekstu nade i oporavka. Doživljaj ponavljane korisnosti od svakodnevnog uzimanja lijeka povezan je i s boljom suradljivošću ${ }^{28}$. Navedeno saznanje možemo iskoristiti u praksi na način da znamo da je uzimanje lijeka proces i da je potrebno vrijeme da se pacijent sam uvjeri da lijek djeluje. Isto je tako i mijenjanje stavova o bolesti postupan proces, stoga nije potrebno inzistirati na tome da pacijent prihvati naše stavove pod svaku cijenu, nego mu treba omogućiti proces ispitivanja vlastitih stavova i ambivalencije prema liječenju. U ovom procesu treba odrediti vrijeme koje je potrebno da pacijent postigne pozitivne stavove prema liječenju i doživi pozitivno iskustvo korisnosti lijekova. Nefleksibilan odnos liječnika koji inzistira na prihvaćanju njegova modela bolesti neće pomoći u ovom procesu, dapače, bit će prepreka i izgubljena prilika za stvaranje suradljivosti. $\mathrm{S}$ druge strane, moramo znati da uvid nije nužan da bi pacijent uzimao lijek; primjerice, kod nekih suradljivih pacijenata u uzimanju antipsihotika nije pronađen uvid ${ }^{29}$. Mnogi pacijenti uzimaju lijek samo zato što im je tako rečeno ${ }^{30}$. Ovo ne znači da moramo odustati od tumačenja informacija pacijentu na način koji je u njegovu interesu, od njegove aktivne uloge u liječenju i rada na izgradnji terapijskog saveza.

\section{Terapijski odnos i suradljivost}

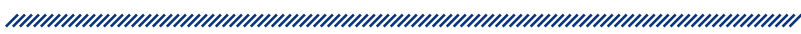

Kvaliteta terapijskog odnosa jedan je od najčešćih faktora koji se povezuju sa suradljivošću ${ }^{12,31,32}$ i predstavlja najkonzistentniji faktor povezan sa suradljivošću u mnogim istraživanjima ${ }^{12}$. Zadovoljstvo pacijenta odnosom liječnik-pacijent dovodi do povećane spremnosti na prihvaćanje savjeta liječnika neovisno o stupnju uvida u bolest. $U$ odnosu liječnik-pacijent potrebno je raditi na terapijskom savezu, zajedničkom radu prema dogovorenom cilju koji potiče aktivnost pacijenta i stavlja ga u ulogu odgovornoga za svoje liječenje. Odluka o uzimanju lijeka mora biti izbor pacijenta u dogovoru s liječnikom na temelju dovoljno informacija o bolesti i korisnosti predloženog liječenja, kao i negativnosti koje bi mogle nastati. Važan je zajednički dogovor o sudjelovanju pacijenta u liječenju. Nažalost, ova dobra prilika za poboljšanje suradljivosti često nije iskorištena jer su osobe sa shizofrenijom rijetko uključene u donošenje odluka o svojem liječenju, a vrlo im često nije rečeno koja je njihova dijagnoza ${ }^{33}$ niti su dobile dovoljno informacija o bolesti i liječenju da bi mogle donijeti odluku. Nije neobično da se osoba optužuje za prekid terapije, a kod pacijenta koji ne slijede savjete liječnika češće će biti narušeni terapijski proces. Značajan broj pacijenata ne govori liječniku da su prestali uzimati lijek jer se boje odbacivanja ili im je neugodno razgovarati o nuspojavama kao što su dobivanje na težini ili seksualne nuspojave. Terapijski je savez u smislu dogovora o ciljevima liječenja put prema kojem je potrebno ići. Zbog različitih psiholoških poteškoća u ostvarenju odnosa povjerenja koji može imati osoba oboljela od shizofrenije i drugih poremećaja s psihozom ovaj proces može biti usporen, ali od njega nikada ne treba odustati, s obzirom na to da se u brojnim istraživanjima pokazuje da je ostvarivanje odnosa povjerenje između liječnika i pacijenta jedan od najkonzistentnijih prediktora ishoda liječenja bez obzira na postupke koji se primijenju ${ }^{32}$. 


\section{Nuspojave lijeka i suradljivost}

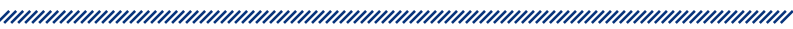

Ekstrapiramidni simptomi najčešće se navode kao razlog prekida uzimanja antipsihotika ${ }^{34}$. Akineza i akatizija povezane su s izrazitom subjektivnom nelagodom i negativnim odgovorom na uzimanje antipsihotika ${ }^{35,36}$. Nuspojave liječenja poput sedacije, porasta težine, seksualne disfunkcije i različitih simptoma povezanih s porastom prolaktina poput galaktoreje i neregularnosti menstrualnog ciklusa također su povezane s nesuradljivošću ${ }^{37}$. Kada pacijent percipira nuspojave kao netolerirajuće, to će obično dovesti do loše suradljivosti ${ }^{38}$. $S$ druge strane, pacijent će nastaviti s uzimanjem lijeka usprkos neugodnim nuspojavama ako doživljava da korist od lijeka nadilazi loše strane lijeka, u ovom slučaju nuspojave ${ }^{39}$. Nuspojave su važne za kvalitetu života i potrebno je osigurati liječenje bez nuspojava ili s minimalnim nuspojavama kada ih nije moguće izbjeći, odnosno potrebno je paziti na to da nuspojave značajno ne remete kvalitetu života niti da pridonose stigmi. Premda su nuspojave važne i jedan od razloga nesuradljivosti, nisu se pokazale kao glavni razlog nesuradljivosti ${ }^{40}$. Za neke je pacijente prisutnost nuspojava značila da lijek djeluje i zbog toga su imali bolju suradljivost ${ }^{41}$, što govori u prilog terapijskom savezu kao zaštitnom faktoru suradljivosti.

\section{Prva i druga generacija antipsihotika}

Dolazak na tržište antipsihotika druge generacije probudilo je nadu da će zbog smanjivanja ekstrapiramidnih nuspojava doći do povećanja suradljivosti ${ }^{13}$. Nažalost, to se očekivanje nije ostvarilo ${ }^{42-45}$. Od atipičnih se antipsihotika jedino klozapin pokazao uspješnim u povećanju suradljivosti, najvjerojatnije zbog toga što se primjenjuje kod terapijske rezistencije na druge lijekove pa se sada korisnost i šteta od uzimanja lijeka promatraju na drugi način, s većom tolerancijom nuspojava. Izbor lijeka vrlo je važan da se izbjegnu nuspojave te poboljšaju neki simptomi poput nesanice, tjeskobe i depresije, što može potaknuti suradljivost ${ }^{46}$.

\section{Drugi faktori povezani s nesuradljivošću}

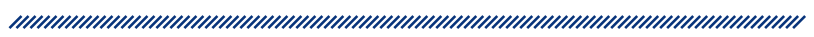

Prisutnost ozbiljnih psihotičnih simptoma bolesti i loš odgovor na primijenjeno liječenje povezani su $s$ nesuradljivošću, odnosno $s$ kvalitetom zadovoljavajućega terapijskog saveza ${ }^{31,47}$. Komorbiditet shizofrenije i drugih psihotičnih poremećaja sa zlouporabom psihoaktivnih tvari također loše djeluje na suradljivost ${ }^{19}$, kao i kognitivna oštećenja, osobito u izvršnim funkcijama ${ }^{23}$. Drugi faktori uključuju način organizacije zdravstvene službe, tako se npr. asertivno liječenje u zajednici povezano s liječenjem u kući pokazalo uspješnim u povećanju suradljivosti ${ }^{48}$. Neadekvatan plan otpusta povezan je s nesuradljivošću. Pozitivni stavovi obitelji prema bolesti ${ }^{23}$ i liječenju povećavaju suradljivost, a neugoda povezana sa stigmom liječenja i lijekova smanjuje suradljivost ${ }^{49}$.

Metaanaliza faktora povezanih sa suradljivošću ${ }^{18}$ pokazala je da sljedeći faktori nisu konzistentni faktori suradljivosti: demografski podatci i faktori povezani sa psihičkom bolešću: dob, spol, etnicitet, bračni status, obrazovanje, neurokognitivna oštećenja, težina psihotičnih simptoma, tip lijeka, ozbiljnost nuspojava, visoke doze antipsihotika, prisutnost simptoma raspoloženja, način primjene lijeka i uključenost obitelji. Najkonzistentniji je faktor povezan sa suradljivošću dobar terapijski odnos.

\section{Postupci za povećanje suradljivosti}

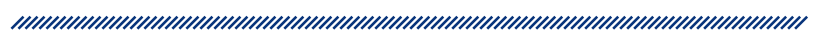

Postupci za povećanje suradljivosti uključuju psihosocijalne postupke, organizirane programe poput asertivnog case managmenta i farmakološke postupke. Ovdje se opisuju psihološki i psihosocijalni postupci koji mogu poboljšati suradljivost. Psihosocijalni postupci uključuju psihoedukaciju, terapiju suradljivosti i kognitivno-bihevioralnu terapiju ${ }^{50-54}$. Mada su se mnogi postupci, poput psihoedukacije, motivacijskog intervjuiranja i kognitivno bihevioralne terapije ${ }^{55}$, pokazali korisnima u povećavanju suradljivosti, nijedna metoda nije bila u prednosti. Psihoedukacijom se pacijent i članovi obitelji osnažuju u razumijevanju i što uspješnijem prihvaćanju bolesti i nošenju s njom $^{56}$. Kognitivno-bihevioralna terapija pomaže u boljem nošenju pacijenta sa simptomima te $s$ disfunkcionalnim emocionalnim reakcijama i ponašanjem koje proizlazi iz 
postojanja psihotičnih simptoma, boljem testiranju realiteta te razvoju povjerenja ${ }^{57}$. Terapija suradljivosti mora biti uključena u cjelovito liječenje i ne može biti posebno izdvojena. Postupci moraju uključiti rad na prihvaćanju bolesti, povlačenje analognih situacija s kroničnom tjelesnom bolešću i uključivanje pacijenta u donošenje odluke. Liječnik ne smije imati osuđujući stav, mora ohrabriti pacijenta da razgovara o neuzimanju lijekova i anticipirati da je za poboljšanje suradljivosti potrebno vrijeme ${ }^{46}$.

Terapiju suradljivosti (engl. adherence therapy) prvi je počeo razvijati Kemp sa suradnicima ${ }^{58,59}$. Cilj je ove terapije promjena stavova prema uzimanju lijekova, što je za pretpostavku imalo poboljšanje kliničkog stanja i prevenciju recidiva bolesti ${ }^{58,59}$. Terapija suradljivosti označena je kao kratki terapijski postupak koji se koristi tehnikom motivacijskog intervjuiranja ${ }^{60,61}$, psihoedukacijom i kognitivnom terapijom $^{58,62}$. Obično se sastoji od tri do četiri seanse u trajanju od 30 do 60 minuta, a primjenjuje se kao pristup kroz nekoliko faza, što se odnosi na: 1 . uvid u povijest bolesti i medikamentoznu terapiju, 2. istraživanje ambivalencije prema liječenju, terapiji održavanja i stigmi te 3. provođenje tehnike rješavanja problema u odnosu na uzimanje lijekova kako bi se uspostavio pozitivan stav prema uzimanju lijekova. Premda je terapija suradljivosti probudila velike nade za uspješno rješavanje problema suradljivosti, analizom različitih istraživanja koja su provjeravala učinkovitost terapije suradljivosti došlo se do zaključka da postoje vrlo ograničeni i nekonzistentni dokazi da terapija suradljivosti dovodi do promjene stavova prema lijekovima te ima utjecaja na simptome i na prevenciju recidiva bolesti i hospitalizacije, stoga se ne preporučuje kao posebna vrsta terapije prema smjernicama NICE-a (National Institute for Health and Care Excellence) ${ }^{46}$. Preporučuje se kombinacija različitih psiholoških pristupa, uključujući navedene, u individualni plan liječenja.

Za razvoj terapijskog odnosa povjerenja potrebno je postojanje obostranog povjerenja između pacijenta i liječnika, uz postojanje obostranog poštovanja i zajedničko donošenje odluka povezanih s terapijskim procesom ${ }^{63}$. Uz to, značajni su čimbenici u razvoju odnosa povjerenja adekvatna i učinkovita komunikacija, osjetljivost na eventualne kulturalne specifičnosti i odsutnost prisile $u$ odnosu ${ }^{64}$. Za razvoj odnosa suradnje između osoblja i pacijenta važno je da se osoblju može pristupiti, da je osoblje neosuđujuće, uključeno, empatično i da poštuje klijentove želje i potrebe ${ }^{64}$.

Psihosocijalni postupci ne djeluju izolirano, dio su nekog plana ili programa liječenja i stoga ih je potrebno primjenjivati prema individualnom planu liječenja i često ih kombinirati. Kada govorimo o psihoedukaciji, postavlja se pitanje kakva je psihoedukacija učinkovita u poboljša- nju suradljivosti. Prema ranije navedenome o faktorima koji povećavaju suradljivost, psihoedukacija bi se trebala koristiti terapijskom efikasnošću terapijskog saveza, postupnošću stvaranja uvida i razumijevanja svoje bolesti, edukativnim elementima - informacijama o bolesti i liječenju te psihoterapijskim elementima.

U Centru za rehabilitaciju u zajednici Klinike za psihijatriju Vrapče ${ }^{65,66}$ primjenjuju se sljedeći principi psihoedukacije koji su prema našem iskustvu pomogli mnogim pacijentima da povećaju suradljivost u uzimanju lijekova, a rad na suradljivosti jedna je od tema koja se obrađuje u programu rehabilitacije. Edukacija o bolesti $^{67}$ uključuje elemente edukacije i psihoterapije. Riječ je o procesu kroz koji pacijent razumije sve više o psihičkoj bolesti, njezinim simptomima, liječenju i prevenciji recidiva. Cilj je „osnaživanje“ - da pacijent doživljava da je u poziciji da utječe na svoju situaciju, umjesto da ima osjećaj da je prepušten na milost i nemilost bolesti. Može se provoditi individualno i grupno. Pri grupnoj edukaciji pomaže učenje preko iskustva drugih. Pacijent je ekspert putem svojeg vlastitog iskustva, a dijeljenje iskustva u grupi može imati veliki terapijski učinak.

Edukacija o bolesti u sklopu upoznavanja sa simptomima bolesti obuhvaća i plan sprječavanja povrata bolesti, koji uključuje prepoznavanje ranih simptoma bolesti, stresnih okolnosti te ranih postupaka primjene lijekova i psihosocijalnih metoda kako bi se spriječio razvoj epizode bolesti ili značajno pogoršanje kliničkog stanja. Odvija se u atmosferi povjerenja, nade i oporavka, što pomaže oboljelima da prihvate liječenje i u njemu aktivno sudjeluju. Važno ju je pružiti i članovima obitelji oboljelih od shizofrenije ${ }^{56}$, što se u sklopu programa provodi u više grupa članova obitelji.

Sve se informacije o bolesti iznose u kontekstu liječenja i oporavka. S psihoedukacijom je potrebno započeti što ranije, a uvijek nakon akutne faze liječenja, u cilju preveniranja sljedeće epizode bolesti. Većina oboljelih prihvaća psihobiosocijalni model bolesti i teoriju preosjetljivosti na stres, kao i koncepcije protektivnih i rizičnih faktora. Znanje o vlastitoj bolesti te o protektivnim i rizičnim faktorima osnovna je polaznica programa prevencije recidiva bolesti. U psihosocijalnom je postupku psihoedukacije s pacijentom potrebno prodiskutirati o individualnim rizičnim i protektivnim faktorima, prepoznavanju ranih simptoma bolesti i o tome što poduzeti kada se pojave rani simptomi bolesti. Uglavnom je riječ o sljedećim aspektima: smanjenje biološke vulnerabilnosti (adekvatna farmakološka terapija i suradljivost u uzimanju lijekova), smanjenje negativnog utjecaja stresa, plan povećavanja sposobnosti i vještina potrebnih za samostalan život i rad (rehabilitacija), porast samopouzdanja, otklanjanje samostigmatiza- 
cije, bolje nošenje sa stigmom i diskriminacijom, traženje podrške (psihoterapija i rehabilitacija) i rano prepoznavanje simptoma pogoršanja. Pacijente treba potaknuti da identificiraju i njeguju protektivne faktore, a izbjegavaju ponašanja povezana s rizičnim faktorima. Protektivni faktori koji čuvaju od pogoršanja uključuju uzimanje lijekova, izbjegavanje alkohola i droga, uredan san, izbjegavanje nepotrebnog stresa, ovladavanje vještinom uspješnijeg svladavanja stresa, razvoj samopouzdanja, podršku prijatelja i obitelji, vještine svladavanja problema rješavanja svakodnevnih teškoća, zdrave stilove življenja i razumijevanje bolesti u kontekstu vlastitog života. Psihoedukacija obuhvaća i rad povezan sa stigmom i diskriminacijom te uključuje učinkovite strategije u borbi protiv samostigmatizacije, stigmatizacije i diskriminacije. Stigma ponekad može biti veća prepreka u izlječenju od same bolesti, stoga je važno identificirati stavove i iskustva povezane sa stigmom i pomoći pacijentu da stigma ne utječe negativno na njegov život. Odnos stigme i lijekova također se obrađuje. Dakle riječ je o postupku koji kombinacijom informacija o bolesti stavljenih u kontekst vlastitog života, rizičnih i preventivnih faktora te psihološkog razumijevanja bolesti postupno dovodi do uvida i osnažuje pojedince da se konstruktivnije nose s bolešću i njezinim posljedicama.

\section{Zaključak}

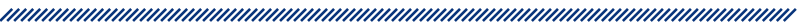

Premda su otkriveni brojni faktori koji pridonose nesuradljivosti u uzimanju antipsihotika i predložene metode, nesuradljivost je i dalje veliki problem. Izbor lijeka i nuspojave utječu na nesuradljivost i mogu dovesti do nesuradljivosti inače suradljivih bolesnika, ali nisu vodeći razlozi nesuradljivosti. Među vodećim razlozima nesuradljivosti ističu se poteškoće u stvaranju i održavanju terapijskog odnosa liječnik-pacijent i nepostojanje uvida u bolest, stoga psihosocijalni postupci postaju vodeći postupci za povećanje suradljivosti. Liječenje osoba oboljelih od shizofrenije i drugih poremećaja sa psihozom složen je zadatak koji uključuje planiranje različitih postupaka. Balansirani pristup psihološkim metodama koje uključuju elemente psihoedukacije, motivacijskog intervjuiranja i stvaranja terapijskog odnosa povjerenja te aktivno uključenje u donošenje odluka o liječenju, orijentaciju prema osnaživanju i oporavku, točne informacije o bolesti i liječenju u kontekstu oporavka i borbu protiv stigme i samostigmatizacije put je koji će pomoći da većina nesuradljivih bolesnika postane i ostane suradljiva u uzimanju antipsihotika koji su učinkovita sredstva u liječenju oboljelih od shizofrenije i poremećaja sa psihozom.

\section{Literatura}

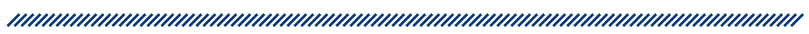

1. Leo RJ, Regno P Del. Atypical Antipsychotic Use in the Treatment of Psychosis in Primary Care. Primary Care Companion to the Journal Of Clinical Psychiatry. 2000;2(6):194-204.

2. AlAqeel B, Margolese HC. Remission in schizophrenia: critical and systematic review. Harvard Review of Psychiatry. 2012;20(6):281-97.

3. Novick D, Haro JM, Suarez D, Perez V, Dittmann RW, Haddad PM. Predictors and clinical consequences of non-adherence with antipsychotic medication in the outpatient treatment of schizophrenia. Psychiatry Research. 2010;176(2-3):109-113.

4. Almond S, Knapp M, Francois C, Toumi M, Brugha T. Relapse in schizophrenia: Costs, clinical outcomes and quality of life. British Journal of Psychiatry. 2004;184:346351.

5. Thornley B, Adams C. Content and quality of 2000 controlled trials in schizophrenia over 50 years. BMJ. 1998;317(7167):1181-1184.

6. Barkhof E, Meijer CJ, de Sonneville LMJ, Linszen DH, de Haan L. Interventions to improve adherence to antipsychotic medication in patients with schizophrenia-A review of the past decade. European Psychiatry. 2012;27(1):9-18.

7. Masand PS, Roca M, Turner MS, Kane JM. Partial adherence to antipsychotic medication impacts the course of illness in patients with schizophrenia: a review. Primary Care Companion to the Journal of Clinical Psychiatry. 2009;11(4):147-154.

8. Babiker IE. Noncompliance in schizophrenia. Psychiatric Developments. 1986;4(4):329-337.

9. Weiden PJ, Olfson M. Cost of relapse in schizophrenia. Schizophrenia Bulletin. 1995;21(3):419-429.

10. Nosé M, Barbui C, Gray R, Tansella M. Clinical interventions for treatment non-adherence in psychosis: Metaanalysis. British Journal of Psychiatry. 2003;183:197-206.

11. Cramer JA, Rosenheck R. Compliance with medication regimens for mental and physical disorders. Psychiatric Services. 1998;49(2):196-201.

12. Weiss KA, Smith TE, Hull JW, Piper AC, Huppert JD. Predictors of risk of nonadherence in outpatients with schizophrenia and other psychotic disorders. Schizophrenia Bulletin. 2002;28(2):341-349.

13. Corrigan PW, Liberman RP, Engel JD. From noncompliance to collaboration in the treatment of schizophrenia. Hospital \& community psychiatry. 1990;41(11):1203-1211.

14. Young JL, Spitz RT, Hillbrand M, Daneri G. Medication adherence failure in schizophrenia: a forensic review of rates, reasons, treatments, and prospects. The Journal of the American Academy of Psychiatry and the Law. 1999;27(3):426-444. 
15. Haynes R, Sackett D, Taylor D, eds. Compliance in Health Care. Baltimore, MD: Johns Hopkins University Press; 1979.

16. Filipović R et al, Preradili Bujas Ž et al. Englesko-Hrvatski Riječnik. 21. izd. (Filipović R, ed.). Zagreb: Školska knjiga; 1995.

17. Haynes RB, McDonald H, Garg AX, Montague P. Interventions for helping patients to follow prescriptions for medications. Cochrane Database of Systematic Reviews (Online). 2002;(2):CD000011.

18. Lacro JP, Dunn LB, Dolder CR, Leckband SG, Jeste D V. Prevalence of and risk factors for medication nonadherence in patients with schizophrenia: a comprehensive review of recent literature. The Journal of Clinical Psychiatry. 2002;63(10):892-909.

19. Olfson M, Mechanic D, Hansell S, Boyer CA, Walkup J, Weiden PJ. Predicting medication noncompliance after hospital discharge among patients with schizophrenia. Psychiatric services. 2000;51(2):216-222.

20. Piette JD, Heisler M, Krein S, Kerr EA. The role of patientphysician trust in moderating medication nonadherence due to cost pressures. Archives of Internal Medicine. 2005;165(15):1749-1755.

21. Brown KW, Billcliff N, McCabe E. Informed consent to medication in long-term psychiatric in-patients. Psychiatric Bulletin. 2001;25(4):132-134.

22. Daltroy L, Katz J, Morlino C, Al. E. Improving doctor patient communication. Psychiatric Medicine. 1991;2:31-5.

23. Perkins DO. Predictors of noncompliance in patients with schizophrenia. Journal of Clinical Psychiatry. 2002;63(12):1121-1128.

24. Bebbington PE. The content and context of compliance. International clinical psychopharmacology. 1995;9 Suppl 5:41-50.

25. Paykel ES, Hart D, Priest RG. Changes in public attitudes to depression during the Defeat Depression Campaign. British Journal of Psychiatry. 1998;173:519-522. doi:10.1192/bjp.173.6.519.

26. Weiden PJ, Kozma C, Grogg A, Locklear J. Partial compliance and risk of rehospitalization among California Medicaid patients with schizophrenia. Psychiatric services. 2004;55(8):886-891.

27. Staring ABP, Van Der Gaag M, Koopmans GT, Selten JP, Van Beveren JM, Hengeveld MW, Loonen AJ, Mulder CL. Treatment adherence therapy in people with psychotic disorders: Randomised controlled trial. British Journal of Psychiatry. 2010;197(6):448-455.

28. Baby R, Gupta S, Sagar R. Attitudes and subjective reasons of medication compliance and noncompliance among outpatients with schizophrenia in India. The Internet Journal of Epidemiology. 2009;7(1).

29. Garavan J, Browne S, Gervin M, Lane A, Larkin C, O'Callaghan E. Compliance with neuroleptic medication in outpatients with schizophrenia; relationship to subjective response to neuroleptics; attitudes to medication and insight. Comprehensive Psychiatry. 1998;39(4):215-219.
30. Gray R, Rofail D, Allen J, Newey T. A survey of patient satisfaction with and subjective experiences of treatment with antipsychotic medication. Journal of Advanced Nursing. 2005;52(1):31-37.

31. Fenton WS, Blyler CR, Heinssen RK. Determinants of medication compliance in schizophrenia: empirical and clinical findings. Schizophrenia Bulletin. 1997;23(4):637-651.

32. Frank AF, Gunderson JG. The role of the therapeutic alliance in the treatment of schizophrenia. Relationship to course and outcome. Archives of General Psychiatry. 1990;47(3):228-236.

33. Baylé FJ, Chauchot F, Maurel M, Ledoriol AL, Gérard A, Pascal JC, Azorin JM, Olie JP, Lôo H. Survey on the announcement of schizophrenia diagnosis in France. L'Encephale. 1999;25(6):603-611.

34. McCann T V., Boardman G, Clark E, Lu S. Risk profiles for non-adherence to antipsychotic medications. Journal of Psychiatric and Mental Health Nursing. 2008;15(8):622-629.

35. Buchanan A. A two-year prospective study of treatment compliance in patients with schizophrenia. Psychological Medicine. 1992;22(3):787-797.

36. Gervin M, Browne S, Garavan J, Roe M, Larkin C, O'Callaghan E. Dysphoric subjective response to neuroleptics in schizophrenia: Relationship to extrapyramidal side effects and symptomatology. European Psychiatry. 1999;14(7):405-409.

37. Haddad PM, Sharma SG. Adverse effects of atypical antipsychotics: differential risk and clinical implications. CNS Drugs. 2007;21(11):911-936.

38. Fleischhacker WW, Meise U, Günther V, Kurz M. Compliance with antipsychotic drug treatment: influence of side effects. Acta Psychiatrica Scandinavica, Supplementum. 1994;89 Suppl 3:11-15.

39. Gaszner P, Makkos Z. Clozapine maintenance therapy in schizophrenia. Progress in Neuro-Psychopharmacology \& Biological Psychiatry. 2004;28(3):465-469.

40. Tacchi M, Nendick J, Scott J. Patient choice and improving the uptake of long-acting injectable medication. In: Haddad P, Lambert T, Lauriello J, eds. Antipsychotic Long-Acting Injections. New York: Oxford University Press; 2011:185-208.

41. Irwin DS, Weitzel WD, Morgan DW. Phenothiazine intake and staff attitudes. American Journal of Psychiatry. 1971;127(12):1631-1635.

42. Diaz E, Neuse E, Sullivan MC, Pearsall HR, Woods SW. Adherence to conventional and atypical antipsychotics after hospital discharge. Journal of Clinical Psychiatry. 2004;65(3):354-360.

43. Dolder CR, Lacro JP, Dunn LB, Jeste DV. Antipsychotic medication adherence: Is there a difference between typical and atypical agents? American Journal of Psychiatry. 2002;159(1):103-108.

44. Gianfrancesco FD, Rajagopalan K, Sajatovic M, Wang RH. Treatment adherence among patients with schizophrenia treated with atypical and typical antipsychotics. Psychiatry Research. 2006;144(2-3):177-189. 
45. Menzin J, Boulanger L, Friedman M, Mackell J, Lloyd JR. Treatment adherence associated with conventional and atypical antipsychotics in a large state Medicaid program. Psychiatric Services. 2003;54(5):719-723. doi:10.1176/appi.ps.54.5.719.

46. National Institute for Health and Clinical Excellence. Schizophrenia: Core Interventions in the Treatment and Management of Schizophrenia in Adults in Primary and Secondary Care. NICE Clinical Guideline 82.; 2009. Dostupno na: http://www.nice.org.uk/CG82 [NICE guideline].

47. Perkins DO, Gu H, Weiden PJ, McEvoy JP, Hamer RM, Lieberman JA. Predictors of treatment discontinuation and medication nonadherence in patients recovering from a first episode of schizophrenia, schizophreniform disorder, or schizoaffective disorder: A randomized, double-blind, flexible-dose, multicenter study. Journal of Clinical Psychiatry. 2008;69(1):106-113.

48. Bush CT, Langford MW, Rosen P, Gott W. Operation outreach: intensive case management for severely psychiatrically disabled adults. Hospital \& community psychiatry. 1990;41(6):647-649.

49. Goff DC, Hill M, Freudenreich O. Strategies for improving treatment adherence in schizophrenia and schizoaffective disorder. The Journal of Clinical Psychiatry. 2010;71 Suppl 2:20-26.

50. Mari JJ, Streiner DL. An overview of family interventions and relapse on schizophrenia: meta-analysis of research findings. Psychological Medicine. 1994;24(3):565-578.

51. Pekkala E, Merinder L. Psychoeducation for schizophrenia. Cochrane Database of Systematic Reviews. 2002;2:CD002831.

52. Pitschel-Walz G, Leucht S, Bäuml J, Kissling W, Engel RR. The effect of family interventions on relapse and rehospitalization in schizophrenia--a meta-analysis. Schizophrenia Bulletin. 2001;27(1):73-92.

53. Bellack A. Psychosocial treatment in schizophrenia. Dialogues in Clinical Neuroscience. 2001;3(2):136-7.

54. El-Mallakh P, Findlay J. Strategies to improve medication adherence in patients with schizophrenia: the role of support services. Neuropsychiatr Dis Treat. 2015;11:1077-90.

55. Zygmunt A, Olfson M, Boyer CA, Mechanic D. Interventions to improve medication adherence in schizophrenia. American Journal of Psychiatry. 2002;159(10):1653-1664.

56. Bäuml J, Froböse T, Kraemer S, Rentrop M, Pitschel-Walz G. Psychoeducation: A basic psychotherapeutic intervention for patients with schizophrenia and their families. Schizophrenia Bulletin. 2006;32 Suppl 1:S1-S9.

57. Turkington D, Dudley R, Warman DM, Beck AT. CognitiveBehavioral Therapy for Schizophrenia: A Review. Focus. 2006;4(2):223-33.

58. Kemp R, Hayward P, Applewhaite G, Everitt B, David A. Compliance therapy in psychotic patients: randomised controlled trial. BMJ. 1996;312(7027):345-349.

59. Kemp R, Kirov G, Everitt B, Hayward P, David A. Randomised controlled trial of compliance therapy. 18-month follow-up. British Journal of Psychiatry. 1998;172:413-419.
60. Miller RM, Rollnick S. Motivational Interviewing. New York; London: Guilford Press; 2002.

61. Barkhof E, Meijer CJ, De Sonneville LMJ, Linszen DH, De Haan L. The effect of motivational interviewing on medication adherence and hospitalization rates in nonadherent patients with multi-episode schizophrenia. Schizophrenia Bulletin. 2013;39(6):1242-1251.

62. Hegedüs A, Kozel B. Does adherence therapy improve medication adherence among patients with schizophrenia? A systematic review. International Journal of Mental Health Nursing. 2014;23(6):490-7.

63. Farrelly $\mathrm{S}$, Lester $\mathrm{H}$. Therapeutic relationships between mental health service users with psychotic disorders and their clinicians: A critical interpretive synthesis. Health and Social Care in the Community. 2014;22(5):449460.

64. Gilburt H, Rose D, Slade M. The importance of relationships in mental health care: a qualitative study of service users' experiences of psychiatric hospital admission in the UK. BMC Health Services Research. 2008;8:92.

65. Štrkalj Ivezić S, Mužinić L, Vidulin I. Program koordiniranog liječenja (case management) u rehabilitaciji osoba s psihotičnim poremećajem. Socijalna psihijatrija. 2009;37:83-91.

66. Brečić $P$, Ostojić $D$, Stijačić $D$, Jukić $V$. Od radne terapije i rekreacije do psihosocijalnih metoda liječenja i rehabilitacije psihijatrijskih bolesnika u bolnici "Vrapče." Socijalna psihijatrija. 2013;41:174-181.

67. Štrkalj-Ivezić S. Psihoza, shizofrenija, shizoafektivni poremećaj, bipolarni poremećaj. Psihoedukacija između informacije i psihoterapije. Zagreb: Medicinska naklada; 2011. 


\section{PSYCHOEDUCATION ABOUT ANTIPSYCHOTICS AS A WAY OF INCREASING ADHERENCE AND TREATMENT EFFICACY}

1 Slađana Štrkalj Ivezić

2 Lana Mužinić

3 Marijo Vrdoljak

1 University Psychiatric Hospital Vrapče

2 Department of Psychiatry, University Hospital Dubrava

3 Home for people with psychiatric disabilities, Zagreb the context of the personal life of the patient and the prospects of recovery, along with the fight against stigma and auto-stigmatization is a way that will help that most non-adherent patients become adherent, and that adherent patients remain adherent.

\begin{abstract}

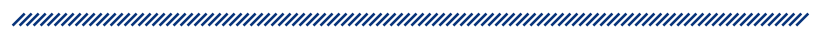

This paper reviews various factors that influence adherence to antipsychotic medication, with the aim of a comprehensive review of adherence to taking medication in patients suffering from schizophrenia and other psychotic disorders. Review of the literature on adherence suggests that the most consistent factors associated with non-adherence are lack of good therapeutic relationship with the patient and lack of insight into the existence of illness, thus suggesting that leading strategies for dealing with non-adherence should be psychosocial. Although many approaches such as psychoeducation and motivational interviewing have proved useful in increasing adherence, including adherence therapy, it can not be concluded that any approach is better. A balanced approach of psychological methods that include elements of psychoeducation, motivational interviewing, creating a relationship of trust, actively engaging in treatment decision-making, orientation toward empowerment and recovery, adequate information about the illness and treatment associated with
Keywords: psychoeducation, adherence, antipsychotics 



\section{Razlike u percepciji sestrinstva između studenata sestrinstva i zaposlenih medicinskih sestara}

1 Snježana Čukljek

1 Martina Smrekar

1 Sanja Ledinski Fičko

2 Vesna Konjevoda

1 Zdravstveno veleučilište

2 KB Sveti Duh

\section{Sažetak}

"

Posljednjih se nekoliko godina, zbog sigurnosti radnog mjesta, sestrinstvo nalazi na listi poželjnih zanimanja u Hrvatskoj. Prilikom odabira profesije budući studenti dolaze s formiranim stavovima o sestrinstvu i cijenjenosti profesije, koji su tijekom studija podložni promjenama.

Cilj ove kvalitativne studije bio je utvrditi mišljenja studenata sestrinstva i zaposlenih medicinskih sestara o zadaćama i ulogama medicinskih sestara, vrijednostima koje se vežu uz sestrinstvo i o prepoznatljivosti sestara te mišljenja ispitanika o tome što pacijenti, liječnici i društvo misle o medicinskim sestrama.

Medicinske sestre i studenti navode da su uloge i zadaće medicinskih sestara briga za pacijente i zadovoljavanje osnovnih ljudskih potreba. Obje skupine ispitanika navode da su medicinske sestre prepoznatljive po uniformi te u vezi s vrijednostima u sestrinstvu najčešće navode pojmove: brižnost i humanost. Zaposlene medicinske sestre najvažnijima smatraju uvjete rada, dok studenti na prvom mjestu navode pacijente, a navode $\mathrm{i}$ važnost znanja i vještina. Zaposlene medicinske sestre i studenti slažu se da pacijenti uglavnom imaju pozitivna i podijeljena mišljenja o medicinskim sestrama. Uočena je razlika u odgovorima medicinskih sestara i studenta s obzirom na njihova mišljenja o tome što društvo i liječnici misle o medicinskim sestrama. Studenti, za razliku od zaposlenih medicinskih sestara, navode da smatraju da društvo i liječnici imaju pozitivnija mišljenja o sestrama. Dio studenata smatra da društvo ima stereotipna mišljenja o medicinskim sestrama.

Rezultati istraživanja ukazuju da na razvoj profesionalnog identiteta i percepcije o sestrinstvu značajan utjecaj imaju mediji, okolina i edukacija. Mišljenja studenata sestrinstva u znatnoj su mjeri usklađena s mišljenjima zaposlenih medicinskih sestara, što može ukazivati na lakše uklapanje na radno mjesto po završetku studija.

Ključne riječi: sestrinstvo, percepcija, profesionalni identitet

Datum primitka: 09.06.2015.

Datum prihvaćanja: 12.09.2015.

Adresa za dopisivanje:

Snježana Čukljek, prof.

Zdravstveno veleučilište

Mlinarska 38, Zagreb

Tel.: 0038514595911

E-pošta: snjezana.cukljek@zvu.hr 


\section{Uvod}

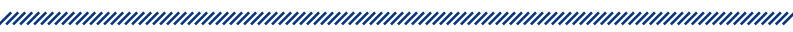

$\mathrm{Na}$ odabir profesije, tako i sestrinske profesije, značajno utječe slika koja se o njoj prezentira u javnosti. Na razvoj slike o profesiji s jedne strane utječu društvo i mediji, a s druge strane same medicinske sestre. Sigurnost radnog mjesta čini sestrinstvo poželjnim zanimanjem i posljednjih se nekoliko godina nalazi na listi poželjnih zanimanja u Republici Hrvatskoj. Prema podatcima Središnjega prijavnog ureda za upise studenata na studije u Republici Hrvatskoj, posljednjih dviju godina na jedno se studentsko mjesto na redovnom studiju sestrinstva Zdravstvenog veleučilišta prijavljuje 12 do 13 kandidata. Studiji sestrinstva postaju sve atraktivniji i za učenike koji su završili nemedicinske srednje škole poput gimnazija, srednjih strukovnih i ekonomskih škola. Prilikom odabira profesije budući studenti dolaze s formiranim stavovima o sestrinstvu i cijenjenosti profesije, koji su tijekom studija podložni promjenama. Nerijetko studenti dolaze s idealističnom i nerealnom percepcijom sestrinske profesije. Tijekom edukacije student usvaja profesionalni identitet i socijalizira se u sestrinskoj profesiji. Profesionalna socijalizacija kompleksan je proces tijekom kojeg osoba usvaja znanja, vještine, stavove i osjećaj profesionalne pripadnosti koji su karakteristični za člana profesije. Na stvaranje profesionalnog identiteta utječu brojni čimbenici, poput kurikuluma, edukatora, kliničkih asistenata, medicinskih sestara na odjelima, obitelji, prijatelja, okoline u bolničkim i izvanbolničkim ustanovama ${ }^{1}$. Iznimno je važno tijekom edukacije primjereno utjecati na razvoj profesionalnog identiteta kako bi se formirali profesionalci koji će se uklopiti u radnu okolinu i primjereno obavljati odabranu profesiju.

Kao razlozi odabira sestrinske profesije u literaturi se navode želja za ljudskim kontaktom, mogućnost pomaganja drugima, osjećaj da rade nešto korisno i sigurnost radnog mjesta ${ }^{2-5}$. Jedan je od razloga za odabir sestrinske profesije i prethodni kontakt s medicinskim sestrama koje su njegovale nekog od članova njihove obitelji, odnosno poznavanje medicinskih sestara (medicinska je sestra član obitelji ili prijatelj obitelji). Značajan je razlog odabira profesije i mobilnost unutar profesije, mogućnost putovanja i rada izvan matične zemlje ${ }^{4}$.

I danas, u 21. stoljeću, medicinske se sestre susreću s problemima povezanima s prezentacijom sestrinstva u javnosti. Nerijetko je u medijima dominantnija stereo- tipna prezentacija medicinske sestre u odnosu na realnu. Stereotipije se značajnije naglašavaju u američkoj sestrinskoj literaturi, no procesi globalizacije čine ih dostupnima svagdje. Dominiraju feminizirani stereotipi, medicinske se sestre prikazuju kao žene, a naglasak se stavlja na tradicionalne ženske uloge (majka, supruga, ljubavnica). Kao najčešći prikazi dominiraju medicinska sestra anđeo, oštrokondža, nestašna (seksi) medicinska sestra i pomoćnica liječnika ${ }^{6-8}$. Nerijetko se uz medicinske sestre vezuje manjak znanja i inteligencije u odnosu na liječnike, kao i poslušnost liječnicima ${ }^{9,}{ }^{10}$. Kao najčešće stereotipije na kanalu YouTube izdvajaju se medicinska sestra kao „vješti znalac i činilac", seksualna igračka i budalasta, nekompetentna osoba ${ }^{11}$.

Upravo zbog utjecaja medija i stvaranja stereotipnih prikaza medicinskih sestara, a u svrhu dobivanja realne slike o sestrinskoj profesiji, proveden je niz istraživanja među medicinskim sestrama i općom populacijom kako bi se utvrdilo mišljenje medicinskih sestara i opće populacije o sestrinstvu. Cohen ${ }^{12}$ navodi da medicinske sestre u Sjedinjenim Američkim Državama smatraju da na stvaranje slike o sestrinstvu najveći utjecaj ima način kako se medicinske sestre prezentiraju pacijentima i njihovim obiteljima, koliko su vješte u obavljanju svojeg posla te mišljenje pacijenta/obitelji je li medicinskim sestrama stalo do pacijenta tijekom skrbi. Manninen ${ }^{13}$ navodi da opća populacija u Finskoj medicinske sestre smatra dobro educiranima, a sestrinstvo cijenjenom profesijom. Donelan i suradnici ${ }^{14}$ navode da društvo u Sjedinjenim Američkim Državama također cijeni medicinske sestre.

Istraživanje provedeno u Hrvatskoj 2011. godine na 3005 ispitanika uključivalo je pitanja o zadovoljstvu građana radom javnih službi te je procjenjivana i kvaliteta javnih usluga na skali od 1 do 4 . Najbolje ocijenjeni javni radnici bile su medicinske sestre s ocjenom 3,24, a liječnici su ocjenjeni ocjenom 3,18 $18^{15}$.

Istraživanje provedeno na studentima treće godine studija sestrinstva u Hrvatskoj ukazuje na to da studenti smatraju da je sestrinstvo potplaćena profesija, kao i da sestre nisu dovoljno cijenjene ${ }^{16}$. Takvi su rezultati dobivani i tijekom istraživanja na studentima završnih godina studija u Kanadi te Sjedinjenim Američkim Državama ${ }^{17,18}$.

Po završetku studija, na početku karijere, studenti imaju uglavnom pozitivno mišljenje o sestrinstvu ${ }^{19}$ te smatraju da su medicinske sestre odgovorne za pad mišljenja o sestrinstvu. Naime smatraju da, ako sestre ne cijene znanje i vještine drugih medicinskih sestara, malo je vjerojatno da će ih cijeniti drugi zdravstveni profesionalci. 
Na početku studija kao osnovne zadatke koje medicinske sestre obavljaju studenti navode medicinskotehničke zadatke i njegovanje, dok na kraju studija navode i aktivnosti povezane s profesionalizacijom sestrinstva zasnovanom na istraživanjima, promocijom zdravlja i profesionalnom skrbi za pacijenta ${ }^{13,20,21}$.

Ova kvalitativna ${ }^{22}$ studija donosi informacije o tome kako studenti studija sestrinstva percipiraju segmente sestrinstva na početku studija te koliko se njihova percepcija razlikuje od percepcije zaposlenih medicinskih sestara. Studija donosi podatke koji mogu utjecati na razvoj profesionalnog identiteta.

\section{Metode}

Cilj istraživanja bio je utvrditi mišljenja studenata studija sestrinstva i zaposlenih medicinskih sestara o zadaćama i ulogama medicinskih sestara, vrijednostima koje se vežu uz sestrinstvo i o prepoznatljivosti medicinskih sestara te mišljenja ispitanika o tome što pacijenti, liječnici i društvo misle o medicinskim sestrama. Također smo željeli utvrditi razlike u mišljenjima između dvije skupine ispitanika (studenata i medicinskih sestara).

$\mathrm{U}$ istraživanju je sudjelovalo 38 studenata prve godine studija sestrinstva Zdravstvenog veleučilišta te 12 zaposlenih medicinskih sestara. Zbog različitosti studenata koji studiraju na studiju sestrinstva, u istraživanje su uključeni studenti s prethodno završenim srednjoškolskim obrazovanjem za medicinske sestre (21 ispitanik) i 17 studenata koji su završili druge srednje škole. Pri tome su u istraživanje uključeni ispitanici sa završenim gimnazijskim obrazovanjem (12 ispitanika) te pet ispitanika sa završenim ostalim srednjim školama (ekonomska, strukovna). Dob ispitanika kretala se u rasponu 18 do 30 godina (prosječna je dob 19,6) i sudjelovala su tri studenta muškog spola.

Zaposlene medicinske sestre rade na klinici za kirurgiju zagrebačke kliničke bolnice. Prosječna dob zaposlenih medicinskih sestara bila je 39,6 godina (raspon od 22 do 60 godina) te su sudjelovala dva ispitanika muškog spola.

U svrhu istraživanja primijenjen je upitnik koji je obuhvaćao demografske podatke (dob, spol), podatke o prethodno završenom obrazovanju te sedam pitanja otvorenog tipa: „Što medicinske sestre rade?“, „Koje su njihove uloge i zadaće?", „Po čemu su medicinske sestre prepoznatljive?“, „Koje se vrijednosti vežu uz medicinske sestre i sestrinstvo?“, „Što je važno medicinskim sestrama?“, „Što pacijenti misle o medicinskim sestrama?“, „Što liječnici misle o medicinskim sestrama?" te „Što društvo misli o medicinskim sestrama?“.

Nakon pristanka na sudjelovanje u istraživanju studentima i medicinskim sestrama ispitivači su podijelili upitnik te su ispitanici anonimno i individualno ispunjavali upitnik, vrijeme odgovaranja na postavljena pitanja nije bilo ograničeno, kao ni duljina odgovora. Svi su odgovori obrađeni, neovisno o duljini.

Glavni je istraživač analizirao sve odgovore ispitanika te ih kategorizirao ovisno o postavljenim pitanjima. Odgovori na pitanja „Što pacijenti misle o medicinskim sestrama?“, „Što liječnici misle o medicinskim sestrama?" te "Što društvo misli o medicinskim sestrama?" kategorizirani su u kategorije: pozitivno, negativno te podijeljena mišljenja. Ostali su istraživači pregledali kategorizacije odgovora te je učinjena završna kategorizacija odgovora.

\section{Rezultati i rasprava}

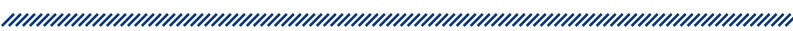

Na pitanja „Što medicinske sestre rade?“ i „Koje su njihove uloge i zadaće?" zaposlene medicinske sestre odgovaraju jednostavno - zdravstvena njega, zadovoljavanje osnovnih ljudskih potreba; te navode najčešće i po njihovoj percepciji najznačajnije intervencije koje obavljaju:

- zadovoljavanje osnovnih ljudskih potreba, edukacija, promicanje zdravlja, čuvanje dostojanstva (medicinska sestra-MS3)

- zbrinjavanje pacijenta od prijama do otpusta, podjela terapije, mjerenje vitalnih znakova, informiranje liječnika o promjenama stanja pacijenta (MS4)

- zdravstvena njega, podjela terapije, vađenje krvi, pratnja bolesnika na dijagnostičke pretrage (MS11).

Studenti u odnosu na zaposlene medicinske sestre opsežnije odgovaraju na pitanje što medicinske sestre rade. Dominiraju odgovori: brinu se za pacijente i zadovoljavanje osnovnih ljudskih potreba. Studenti navo- 
de i kako bi se sestre pritom trebale ponašati: svakom bolesniku pridaju jednaku važnost (student - S21), treba biti požrtvovna u svom radu, empatična, mora surađivati s ostalim članovima tima (S13). Dio studenata nabraja medicinskotehničke zadatke poput kupanja, slaganja kreveta, podjele terapije i asistiranja liječnicima.

Budući da je istraživanje provedeno tijekom drugog semestra studija i do tada su studenti odslušali veći dio nastave, uočljiv je utjecaj teorijskog dijela edukacije u odgovorima studenata. Studenti navode definicije i sadržaje koji su prezentirani tijekom predavanja i seminara:

- Pomoć pojedincu, bolesnom ili zdravom, u obavljanju aktivnosti koje pridonose zdravlju, oporavku ili mirnoj smrti, a koje bi obavljao samostalno kad bi za to imao potrebnu snagu, volju ili znanje. (S14)

- Medicinske sestre provode postupke i intervencije koji pridonose poboljšanju zdravlja pacijenta ili mirnoj smrti. Njihova je uloga da se brinu za pacijenta i njegovu obitelj, da sudjeluju u dijagnostičkim postupcima te provode zdravstvenu njegu $i$ intervencije koje se odnose na zadovoljavanje osnovnih ljudskih potreba kod pacijenta. (S12)

- Pomoć bolesnom i zdravom pojedincu u sprječavanju bolesti, liječenju, oporavku ili mirnoj smrti. Orijentirane su prema pacijentima i njihovim obiteljima, pružaju fizičku i psihičku pomoć. (S3)

- Medicinske se sestre brinu o pacijentima, njihovim osnovnim ljudskim potrebama, promiču i održavaju zdravlje, planiraju, provode i vrednuju zdravstvenu njegu. (S17)

Kod studenata su uočljivi opsežniji i obuhvatniji odgovori, što je vjerojatno posljedica svladavanja sadržaja na teorijskom dijelu nastave. Studenti navode i vrlo složene intervencije poput promicanja zdravlja, sprječavanja bolesti te provođenja i vrednovanja zdravstvene njege, no pitanje je koliko su navedene intervencije njima poznate i koliko razumiju što obuhvaćaju.

Dvije trećine zaposlenih medicinskih sestara navode da su prepoznatljive po uniformi, uz uniformu navode nasmijano lice, težak rad i komunikativnost.

Većina studenta navodi da su sestre prepoznatljive po uniformi, uz uniformu studenti koji su završili srednju medicinsku školu navode humanost i brižnost. Studenti koji su prije upisa na studij završili gimnaziju i druge škole navode i male plaće te težak i zahtjevan posao.

Kao vrijednosti koje se vežu uz sestrinstvo zaposlene medicinske sestre najčešće navode brižnost, huma- nost, požrtvovnost i stručnost. U navodima dominiraju vrijednosti koje se odnose na karakterne osobine (brižnost, strpljivost, susretljivost).

Studenti studija sestrinstva koji su prethodno završili srednju medicinsku školu najčešće navode humanost, brižnost, dobrotu, požrtvovnost i empatiju. Studenti koji su završili druge srednje škole kao vrijednosti izdvajaju humanost, dobrotu, komunikativnost, empatiju, ljubaznost i požrtvovnost. Dio studenata koji su završili druge srednje škole kao vrijednost navode i hrabrost. Studenti uz vrijednosti koje se odnose na karakterne osobine češće navode i vrijednosti koje se vezuju uz obavljanje posla (spretnost, radišnost, odgovornost, strpljivost).

Studenti navode više pojmova povezanih s vrijednostima u odnosu na zaposlene medicinske sestre $(55: 21)$, no najčešći su pojmovi koji navode sestre i studenti jednaki: brižnost i humanost.

Na pitanje „Što je važno medicinskim sestrama?“ zaposlene medicinske sestre najčešće navode uvjete rada (sredstva za rad, dovoljan broj osoblja), potom status (da su cijenjene, adekvatno plaćene) te stanje pacijenta (zadovoljan pacijent, zdravlje pacijenta).

Studenti sestrinstva u najvećoj mjeri navode zadovoljstvo pacijenta, potom profesionalni status (cijenjena profesija) te znanje i vještine (posjedovanje znanja $i$ vještina kako bi mogla kvalitetno provoditi zdravstvenu njegu i edukaciju te stvoriti odnos povjerenja (S1)), timski rad i profesionalnost.

U dijela studenta prisutan je idealističan pogled na profesiju, što je svojstveno studentima. Najvažnije je pomoći pacijentima koliko je to u njihovoj moći i vidjeti osmjeh na pacijentovu licu. (S14)

Zaposlene medicinske sestre ističu uvjete rada, što se može povezati s teškom ekonomskom situacijom i nezapošljavanjem novog osoblja, dok studenti na prvom mjestu navode pacijente, ali navode važnost znanja i vještina jer prepoznaju da im nedostaju upravo znanje i vještine sestrinske prakse.

Profesionalci na osnovi vlastitih doživljaja, ali i stava javnosti, pojedinaca i medija stvaraju sliku o tome kako in drugi doživljavaju. Medicinske sestre u neprestanoj su interakciji s pacijentima i liječnicima te je stoga iznimno značajno znati što one misle o tome kako ih doživljavaju pacijenti, liječnici i društvo.

Većina medicinskih sestara (8) navodi da pacijenti imaju pozitivno mišljenje o medicinskim sestrama, da misle 
da sestre mnogo rade, slabo su plaćene te da su savjesne, brižne, stručne i vrijedne. Samo je jedna ispitanica navela da pacijenti imaju negativno mišljenje o medicinskim sestrama, a jedna navodi: Mišljenja su različita, ovise o obrazovanju, prijašnjem iskustvu, očekivanjima pacijenata. (MS5)

Većina studenata (18) navodi da pacijenti imaju podijeljena mišljena o medicinskim sestrama te da ona ovise o iskustvu pacijenta.

- Ovisi kako koji pacijent, to uvelike ovisi o ponašanju medicinske sestre. Ako je sestra profesionalna, pacijent će naći riječi hvale za nju. Ako je neprofesionalna, pacijent će o njoj imati loše mišljenje i to će i pokazati svojom neverbalnom i verbalnom komunikacijom. (S13)

- Ovisi o iskustvima pacijenata, neki imaju pozitivno mišljenje o sestrama, ali ima i onih koji zbog loših iskustava nemaju dobro mišljenje o njima. (S16)

Šesnaestero je studenata navelo da pacijenti imaju pozitivna mišljenja o medicinskim sestrama, dio studenata navodi idealistična mišljenja: Sve najbolje, misle da su one njihovi anđeli (S17); Uvijek tu za njih, anđeo čuvar (S10); Smatraju ih svojim anđelima čuvarima. (S3). Za razliku od zaposlenih medicinskih sestara, nijedan student ne misli da pacijenti imaju isključivo negativno mišljenje o sestrama, no studenti navode stereotipne prikaze medicinskih sestara.

Price $^{23}$ navodi da studenti formiraju mišljenja na temelju interakcija sa sestrama i iskustva na vježbama te da je kod dijela studenta prisutan idealističan doživljaj sestrinstva koji može uzrokovati poteškoće i nezadovoljstvo prilikom boljeg upoznavanja profesije i zapošljavanja. Prilikom zapošljavanja diplomirani student suočava se s nerazmjerom idealne slike o profesiji koju posjeduje i realnosti. Kod studenata s nerealnom slikom profesije prisutno je češće odustajanje od nastavka i završetka studija ${ }^{24}$.

Studenti svoja mišljenja formiraju na osnovi svojih dosadašnjih iskustava s pacijentima, a dio studenata ima relativno malo iskustva, s obzirom na to da je riječ o studentima prve godine studija, a neki od njih prethodno nisu završili srednju školu za medicinske sestre. Dio ispitanika navodi i stereotipne prikaze medicinskih sestara gdje je vidljiv utjecaj teorijskog dijela nastave i medija na formiranje mišljenja.

Medicinske sestre u manjoj mjeri misle da liječnici o sestrama misle pozitivno, većina sestara (6) smatra da liječnici imaju podvojena mišljenja i većina je navela da liječnici smatraju da sestre moraju stalno biti dostupne liječnicima i slušati ih. Zaposlene medicinske sestre mišljenja stječu na temelju svakodnevnih iskustava na radnom mjestu. Budući da je istraživanje provedeno na jednoj klinici (nekoliko odjela), mišljenja mogu biti uvjetovana međuljudskim odnosima na tim odjelima, odnosno njihovim dosadašnjim iskustvima, i nije ih moguće generalizirati.

Kod studenata dominiraju pozitivna (16) i podijeljena (13) mišljenja, a dio studenata (8) navodi negativna mišljenja liječnika o medicinskim sestrama. Studenti prve godine studija imaju malo kliničkih bolničkih iskustava i iskustva u izravnom radu s liječnicima te se može pretpostaviti da je takvo mišljenje posljedica stereotipija s kojima su se susreli u literaturi i javnim medijima. Studenti formiraju mišljenja i promatrajući odnos medicinska sestra - liječnik tijekom kliničke prakse.

- Na zadnjoj praksi vidjela sam odličnu kompatibilnost među doktorima, sestrama i ostalog osoblja, što me divno iznenadilo. (S15)

No ipak većina studenata, više od dvije trećine, za razliku od zaposlenih medicinskih sestara, smatra da liječnici imaju pozitivna i podijeljena mišljenja. Studenti u manjoj mjeri navode da liječnici smatraju medicinske sestre podređenima. Navedena su mišljenja iznimno značajna za budući timski rad i suradnju s liječnicima.

Budući da zaposlene medicinske sestre imaju značajan utjecaj na formiranje stavova prema profesiji ${ }^{23,25}$, vrlo je važno odabrati pozitivnu okolinu za poučavanje studenata, jer dolazak u sredinu u kojoj dominiraju negativna mišljenja može potaknuti razvoj i učvršćivanje negativnih mišljenja kod studenata.

Zaposlene medicinske sestre smatraju da društvo ima negativna mišljenja (8) o medicinskim sestrama: Da ništa ne rade, šeću u uniformi (MS4); Da šetamo hodnicima, da smo previše plaćene (MS9); Ništa ne rade, samo piju kavu.(MS11). Samo je jedna ispitanica navela: Društvo ima visoko mišljenje o sestrama, smatraju da su one žrtve svog posla, da su podcijenjene, da rade u lošim uvjetima (MS2). Pet od 12 ispitanica navelo je da društvo smatra da su medicinske sestre slabo odnosno premalo plaćene.

Gotovo trećina ispitanih studenata (11) navodi da društvo ima stereotipna mišljenja o medicinskim sestrama (oštrokondža, seksualni objekt, anđeo, pomoćnica liječnika), a nijedna zaposlena medicinska sestra nije navela navedene stereotipije. Mišljenja studenata na- 
stala su pod utjecajem edukacije. Budući da se tijekom predavanja prezentiraju navedene stereotipije, studentima su poznatije i lakše im ih je navesti. Jednaki broj studenta $(7+7)$ navodi da društvo ima pozitivno ili negativno mišljenje o medicinskim sestrama. Preostali dio studenata (12) ima podijeljena mišljenja: Društvo misli kako se medicinske sestre bave jednim od najhumanijih zanimanja. Nažalost, postoje i oni koji imaju stereotipe o medicinskim sestrama, društvo zna biti povedeno medijima. (S14).

Razdoblje bolesti posebno je osjetljivo razdoblje u kojem se lako mogu stvarati i negativni stavovi prema profesiji, posebno ako je pacijent očekivao (opravdano ili neopravdano) znatno veću podršku i pomoć medicinskih sestara. Također i ishod liječenja može utjecati na stvaranje mišljenja o sestrinstvu kao profesiji te ne čudi da dio populacije ima i negativan stav o sestrinstvu i da to studenti prepoznaju, kao ni da prepoznaju postojanje podijeljenih mišljenja.

Studenti smatraju da pacijenti, liječnici i društvo imaju pozitivnija mišljenja o medicinskim sestrama nego što to smatraju zaposlene medicinske sestre. $U$ ovom istraživanju medicinske sestre u većoj mjeri smatraju da liječnici i društvo imaju podijeljena odnosno negativna mišljenja o medicinskim sestrama, no svakako treba uzeti u obzir da je riječ o malom broju ispitanika i da bi trebalo provesti istraživanja na većem broju ispitanika koji dolaze iz različitih radnih sredina.

\section{Zaključak}

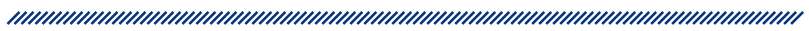

Sigurnost radnog mjesta čini sestrinstvo poželjnim zanimanjem, u proces obrazovanja studenti ulaze s različitim predznanjima povezanima s osobitostima profesije, poslovima i zadatcima koje bi trebali obavljati po završetku obrazovanja. Tijekom obrazovanja razvija se profesionalni identitet i u odgovorima studenta uočljiv je utjecaj edukativnih sadržaja, posebice u odgovorima na pitanja što medicinske sestre rade te pri navođenju stereotipija o sestrinstvu. U manjeg broja studenta prisutna su idealistična razmišljanja i nema značajnijih razlika u odgovorima između studenta koji su prethodno završili srednju školu za medicinske sestre u odnosu na studente koji su završili druge srednje škole. Bilo bi zanimljivo među studentima provesti jednako istraživanje na početku edukacije, prije svladavanja sadržaja povezanih sa sestrinstvom.

Zaposlene medicinske sestre i studenti slažu se u tome da pacijenti uglavnom imaju pozitivna i podijeljena mišljenja o medicinskim sestrama. Uočena je razlika u odgovorima zaposlenih medicinskih sestara i studenta s obzirom na njihova mišljenja o tome što društvo i liječnici misle o medicinskim sestrama. Studenti, za razliku od zaposlenih medicinskih sestara, navode da smatraju da društvo i liječnici imaju pozitivna mišljenja o medicinskim sestrama.

Rezultati istraživanja ukazuju na to da na razvoj profesionalnog identiteta i percepcije o sestrinstvu značajan utjecaj imaju mediji, okolina ali i edukacija. Mišljenja studenata sestrinstva u značajnoj su mjeri usklađena s mišljenjima zaposlenih medicinskih sestara, što može ukazivati na lakše uklapanje na radno mjesto po završetku studija. No s obzirom na to da edukacija i edukativna sredina imaju značajan utjecaj na razvoj profesionalnog identiteta, važno je odabirati kliničke edukacijske sredine koje će omogućavati pozitivan profesionalni razvoj.

Budući da je ovo kvalitativno istraživanje provedeno na maloj skupini ispitanika, samo u jednoj obrazovnoj i jednoj kliničkoj instituciji, potreban je oprez prilikom generalizacije rezultata. Kako bi se dobili vjerodostojniji podatci, potrebno je upitnik prilagoditi za kvantitativnu analizu i primijeniti ga na većem broju ispitanika, u više obrazovnih i kliničkih sredina. 


\section{Literatura}

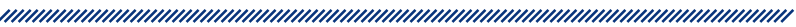

1. Safadi RR, Saleh MYN, Nassar OS, Amre HM, Froelicher ES. Nursing students' perceptions of nursing: a descriptive study of four cohorts. International Council of Nurses. International Nursing Review. 2011;58(4):420-7.

2. Boughn S. Why women and men choose nursing. Nursing and health care perspectives. 2001;22(1):14-19.

3. Bolan C, Grainger P. Students in the BN program - Do their perceptions change? Nurse Education Today. 2009;29:775-779.

4. Mooney M, Glacken M, O’Brien F. Choosing nursing as a career: a qualitative study. Nurse Education Today. 2008;28:358-392.

5. Hemsley-Brown J, Foskett NH. Career desirability: young people's perception of nursing as a career. Journal of Advanced Nursing. 1990;29(6):1342-1350.

6. Cunningham A. Nursing stereotypes. Nursing Standard. 1999;45:46-47.

7. Kalisch BJ, Begeney S, Neuman S. The image of the nurse on the Internet. Nursing outlook. 2007;55:182-188.

8. Bridges JM. Literature review on the images of the nurses and nursing in the media. Journal of Advanced Nursing. 1990;15:850-854

9. Takase M, Maude P, Manias E. Imapct of the perceived public image of nursing on nurses' work behavior. Journal of Advanced Nursing Practice. 2006; 53 (3):333-343.

10. Nielson GR, Lauder W. What do high academic achieving school pupils really think about career in nursing: Analysis of the narrative from paradigmatic case interviews. Nurse Education Today. 2008;28:680-690.

11. Kelly J, Fealy GM, Watson R. The image of you: constructing nursing identities in YouTube. Journal of Advanced Nursing. 2012;68(8):1804-1813.

12. Cohen S. Reflections on the image of nursing [Internet]. Strategies for nurse managers.com. Dostupno na: www. hcpro.com (pristupljeno 10.08.2013.)

13. Manninen E. Changes in nursing students' perceptions of nursing as they progress through their education. Journal of Advanced Nursing. 1998;27:390-398.

14. Donelan K, Buerhaus P, DesRoches C, Dittus R, Dutwin $D$. Public perceptions of nursing careers: the influence of the media and nursing shortages. Nursing economics. 2008;26(3):143-165.

15. Građani Hrvatske: Medicinske sestre najbolji javni službenici [Internet]. Dostupno na: http://nurse.hr/novosti/novosti_sestrinstvo/medicinske-sestre-najbolje. html (Pristupljeno 13.05.2011.)

16. Čukljek S, Karačić J, Ilić B. Stavovi studenata 3. godine studija sestrinstva o sestrinstvu u Hrvatskoj danas. U: Zbornik radova konferencije medicinskih sestara "Hrvatsko sestrinstvo ususret Europskoj uniji“; 24-26.ožujka 2011; Opatija, Hrvatska. Zagreb: Zdravstveno veleučilište; 2011. 169-176.
17. Buerhaus P, Donelan K, Norman L, Dittus R. Nursing students' perceptions of a career in nursing and impact of a national campaign designed to attract people into the nursing profession. Journal of Professional Nursing. 2005;21(2):75-83.

18. Grainger P, Bolan C. Perceptions of nursing as a career choice of students in the Baccalaureate nursing program. Nurse Education Today. 2006;26:38-44.

19. Emeghebo L. The image of nursing as perceived by nurses. Nurse Education Today. 2012;32(6):e49-e53.

20. Granum V. Nursing students perceptions of nursing as a subject and a function. Journal of Nursing Education. 2004;43:297-304.

21. Bolan C, Grainger P. Students in the BN program - Do their perceptions change? Nurse Education Today. 2009;29:775779.

22. Vuletić, S. Kern J. Osnove metodologije javnozdravstvenih istraživanja. Zagreb: Medicinski fakultet Sveučilišta u Zagrebu, Škola narodnog zdravlja Andrija Štampar; 2011.

23. Price SL. Becoming a nurse: a meta study of early professional socialization and career choice in nursing. Journal of Advanced Nursing. 2009;65(1):11-19.

24. Cowin LS, Johnson M. Many paths lead to nursing: factors influencing students' perceptions of nursing. International Nursing Review. 2011;58:413-419.

25. Karaoz S. Change in nursing student' perceptions of nursing during their education: the role of the Introduction to Nursing course in this change. Nurse Education Today. 2004;24:128-135. 


\section{DIFFERENCES IN THE PERCEPTION OF THE NURSING PROFESSION BETWEEN NURSING STUDENTS AND EMPLOYED NURSES}

1 Snježana Čukljek

1 Martina Smrekar

1 Sanja Ledinski Fičko

2 Vesna Konjevoda

1 University of Applied Health Sciences

2 University Hospital Sveti Duh

\section{Abstract

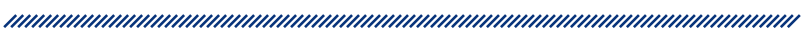

In recent years, due to job security, nursing has been among the desirable professions in Croatia. While choosing their profession, prospective students enter higher education with formed attitudes towards nursing and the esteem of the profession, which can change during the course of their studies.

The aim of this qualitative study was to identify the opinions of nursing students and employed nurses about the tasks and roles of nurses, nursing values, recognizability of nurses, and what patients, doctors and society think about nurses.

Employed nurses and nursing students state that the tasks and roles of nurses are caring for the patients and satisfying basic human needs. Both groups of respondents point out that nurses are recognizable by their uniform, and among nursing values they most often emphasize caring and humaneness. Working conditions are the most important for employed nurses, while nursing students first mention caring for the patient and the importance of knowledge and skills. Both the employed nurses and nursing students agree that patients mainly have either positive or divided opinions about nurses. There was a difference in the answers between employed nurses and nursing students related to their opinion on what the society and doctors think about nurses. Students state, contrary to employed nurses, that the society and doctors have a more positive opinion about nurses. A certain number of students state that the society has stereotyped opinions about nurses.

Research results indicate that the media, society and education have a significant impact on the development of professional identity and perception of nursing. Students' opinions substantially match the opinions of employed nurses which may indicate their easier integration in the workplace after graduation.

Keywords: nursing, perception, professional identity 


\section{Stigmatiziraju li studenti i studentice sestrinstva oboljele od posttraumatskog stresnog poremećaja?}

1 Josipa Rožman

1 Goran Arbanas

1 Opća bolnica Karlovac, Odjel psihijatrije, Andrije Štampara 3, 47000 Karlovac

\section{Sažetak}

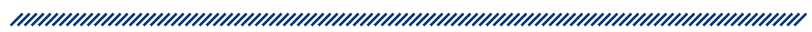

Psihijatrijski bolesnici, osim poteškoća povezanih sa svojim primarnim oboljenjem, suočeni su i s poteškoćama koje proizlaze iz njihove stigmatizacije u sredini u kojoj žive. Diskriminirajuća ponašanja poput ograničavanja zdravstvene skrbi ili prava na obrazovanje i različitih situacija povezanih sa zapošljavanjem samo su neki od primjera koji mogu dodatno ugroziti i fizičko i psihičko zdravlje stigmatiziranih osoba. Stigmatizacija dovodi do sniženja samopoštovanja te do osjećaja izolacije, usamljenosti i diskriminacije, što dodatno otežava liječenje primarne bolesti.

Stigma je čest pratitelj psihičkih bolesti koji ometa liječenje i funkcioniranje. U Republici Hrvatskoj nakon Domovinskog rata postoji velik broj oboljelih od posttraumatskog stresnog poremećaja (PTSP), koji se u medijima često prikazuju na negativan način.

Ovo je istraživanje provedeno na 94 studenta i studentica sestrinstva. Žena je bilo $85 \%$, prosječne dobi od 32 godine (raspon od 22 do 54). Stigma prema shizofreniji, depresiji i PTSP-u ispitivana je upitnikom koji se sastoji od po 15 izjava o svakoj od bolesti, koje se ocjenjuju po Likertovoj ljestvici.

\begin{abstract}
Studenti su pokazivali značajno veću stigmu prema shizofreniji nego prema PTSP-u i depresiji. Žene su bile više stigmatizirajuće prema shizofreniji. Studenti prve godine više su stigmatizirajući prema PTSP-u od studenata druge i treće godine. Stariji studenti (od 36 godina) bili su više stigmatizirajući od mlađih.
\end{abstract}

Ključne riječi: stigma, shizofrenija, depresija, PTSP, studenti sestrinstva

Datum primitka: 19.07.2015.

Datum prihvaćanja: 08.09.2015.

\section{Adresa za dopisivanje:}

Josipa Rožman, bacc.med.tehn.

Opća bolnica Karlovac

Andrije Štampara 3, Karlovac

Tel.: 0958019871

E-pošta: josipa.rozman@bolnica-karlovac.hr

\section{Uvod}

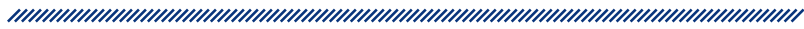

Svjetska zdravstvena organizacija (SZO) definirala je mentalno zdravlje kao stanje dobrobiti u kojem pojedinac ostvaruje svoje potencijale, može se nositi s normalnim životnim stresom, može raditi produktivno i plodno te je sposoban pridonositi zajednici. Tijekom povijesti, sve do danas, psihičke su bolesti bile praćene socijalnim odbacivanjem, strahom i stigmom ${ }^{1}$. Sti- 
gmatiziranje osoba oboljelih od psihičkog poremećaja temelji se na predrasudama te nastaje na temelju nedovoljnog znanja o psihičkim bolestima. Riječ stigma imenica je grčkog podrijetla koja dolazi od korijena čije je značenje „naglasiti, istaknuti, označiti“. Ova je riječ preuzeta metaforički i predstavlja oznaku srama ili degradacije ${ }^{2}$.

U Hrvatskoj je nakon Domovinskog rata više od 7500 ljudi zbog obolijevanja od posttraumatskog stresnog poremećaja (PTSP) ostvarilo status hrvatskoga ratnog vojnog invalida. Tijekom proteklih dvadeset godina, nakon početne podrške i pozitivnog stava prema braniteljima, u medijima dolazi do sve negativnijeg prikaza branitelja i oboljelih od PTSP-a. Frančišković, Stevanović, Blažić i sur. ${ }^{3}$ pokazali su da se prikaz oboljelih od PTSP-a u dnevnim i tjednim novinama mijenjao te da se tijekom razdoblja od deset godina povećao broj članaka koji prikazuju negativne aspekte PTSP-a (npr. crna kronika, suicidi), a smanjio se broj članaka (čak tri puta) koji prikazuju pozitivne aspekte (npr. godišnjice, sjećanja). Poznato je da mediji pridonose stigmatizaciji psihičkih bolesti, prikazujući ih kao nepredvidljive, nasilne i opasne, a u filmovima se psihičke bolesnike znalo prikazivati kao ubojice ${ }^{2,3}$. Čak $72 \%$ psihički bolesnih likova iz TV drama portretirano je kao nasilno, a sve veći broj popularnih filmova koji povezuju psihički poremećaj s nasiljem (Psiho, Petak 13., Kad jaganjci utihnu, Sedam, Isijavanje itd.) samo govori u prilog raširenosti stereotipa koji je prisutan i danas 4 .

Primjeri su ovakvog senzacionalističkog i stigmatizirajućeg pristupa prema oboljelima od PTSP-a u dnevnim medijima: „47-godišnji umirovljeni vojnik, koji iz ratnog razdoblja vuče PTSP, zatvorio se u svoju kuću u Crnom Selu te je prijetio da će pobiti sve koji mu se približe“ (http://www.rtl.hr/vijesti/novosti/15769/ptsp-ovacprijetio-da-ce-pobiti-sve/ pristupljeno 2. lipnja 2014); „PTSP-ovac zatočio službenike Mirovinskog“ (http:// www.jutarnji.hr/ptsp-ovac-zatocio-sluzbenike-mirovinskog/271267/ pristupljeno 2. lipnja 2014.); „Rastrojeni hrvatski branitelj popeo se na krov svoje kuće te je s kanistrom punim benzina dva sata prijetio da će zapaliti i sebe i kuću u kojoj mu je bila obitelj“ (http://www.rtl. hr/vijesti/novosti/3738/na-krovu-prijetio-samozapaljenjem/ pristupljeno 2. lipnja 2014.). Takvim pisanjem mediji pretvaraju incidentnu situaciju u stigmu prema svim oboljelima te na taj način povećavaju ionako stigmatizirajuće mišljenje javnosti o psihičkim bolesnicima. Osobe oboljele od PTSP-a dojma su da su slabo prihvaćeni od opće populacije, čemu svakako pridonosi i ovakav prikaz bolesti u novinskim izvješćima. Brojna istraživanja provedena na ovom polju pokazuju da ispitanici najčešće percipiraju osobe sa shizofrenijom kao nepredvidljive i opasne ${ }^{5}$. Psihičke bolesnike stigmatiziraju ne samo laici nego i zdravstveni djelatnici. Filipčić i sur. pokazali su prisutnost predrasuda i stigmatizirajućih stavova kod liječnika, medicinskih sestara i tehničara te studenata medicinskog fakulteta ${ }^{6}$. Lai i sur. u istraživanju na uzorku od 300 psihički oboljelih osoba, 100 zdravstvenih djelatnika i 50 osoba oboljelih od kardiovaskularnih bolesti također su dokazali kako je razina stigme prema psihički oboljelim osobama velika te su ukazali na važnost povećavanja javne svijesti o psihičkim bolestima ${ }^{7}$ I same osobe oboljele od psihičkih bolesti imaju stigmatizirajuće stavove prema tim istim psihičkim bolestima ${ }^{8}$, kao i članovi obitelji oboljelih od psihičkih bolesti ${ }^{9}$. Pri tome se osobe sa psihičkim bolestima najčešće doživljavaju kao opasne i nasilne te nesposobne za samostalan život, donošenje odluka, za život i privređivanje. Istraživanje koje je proveo Wahl na uzorku od 100 psihički oboljelih osoba pokazalo je njihovo iskustvo stigme iz raznih izvora, uključujući društvene i poslovne zajednice, obitelj i crkvu. Većina ispitanika prikrivala je svoje bolesti i pokazala veliku razinu zabrinutosti zbog mogućnosti otkrivanja njihovih bolesti ponajviše radi reakcija okoline ${ }^{10}$.

Usporedba stigmatizacije psihički oboljelih osoba u periodu od 1950. do 1996. g. pokazala je kako je percepcija o psihičkim bolesnicima kao nasilnima i zastrašujućima porasla, što je bilo iznenađujuće jer je očekivano da će u razdoblju velikog napretka medicine napredovati i svijest opće populacije o psihički oboljelim osobama u pozitivnom smislu ${ }^{11}$. Zbog stigme se oboljeli ne koriste uslugama službi za zaštitu psihičkog zdravlja, slabije se pridržavaju liječenja i umanjena im je mogućnost zapošljavanja ${ }^{12}$. Učinak stigme može biti teži i dugotrajniji nego učinak same psihičke bolesti. Psihijatrijski bolesnici, osim poteškoća povezanih s njihovim primarnim oboljenjem, suočeni su i s poteškoćama koje proizlaze iz njihove stigmatizacije u sredini u kojoj žive. Rezultati istraživanja koje su proveli Jokić Begić i sur. 2005. godine ukazali su na široko prihvaćen negativan stereotip o psihičkim bolesnicima. lako stavovi prema njima variraju od neutralnih do pozitivnih, prihvaćanje psihičkih bolesnika je znatno slabije: više od $50 \%$ sudionika pokazalo je veću socijalnu distancu prema njima. Rezultati su također pokazali da što više ljudi znaju o psihičkim bolesnicima, to su pozitivniji njihovi stavovi prema njima i veći je stupanj prihvaćanja takvih osoba ${ }^{13}$. Unatoč tome, dosadašnja istraživanja u Hrvatskoj pokazala su da je stav mladih ljudi u Hrvatskoj prema PTSP-u manje 
obojen stigmom nego stav prema shizofreniji ${ }^{14}$. Nažalost, istraživanja stigme prema PTSP-u malobrojna su i u svjetskim razmjerima. S obzirom na to da se oboljeli od PTSP-a često koriste zdravstvenim uslugama, ne samo u području psihičkog zdravlja nego i u području „organske" medicine (a zbog činjenice da oboljeli od PTSP-a imaju povišene stope kardiovaskularnih, endokrinoloških, gastrointestinalnih i niza drugih bolesti), željelo se vidjeti kakav je stav studenata sestrinstva prema oboljelima od ovog poremećaja. Studenti sestrinstva osobe su koje imaju specifična znanja, ali i ranije iskustvo u radu s bolesnicima te su vjerojatno dolazili u doticaj i s oboljelima od PTSP-a. Zbog brojnih dosada provedenih istraživanja stigme prema shizofreniji i depresiji, upravo su ove dvije bolesti odabrane kao usporedba u odnosu na PTSP.

\section{Metoda}

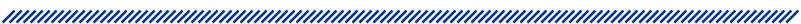

\section{Sudionici}

Istraživanje je provedeno na uzorku od 129 izvanrednih studenata prve, druge i treće godine Stručnog studija sestrinstva u Karlovcu, dislocirani studij Medicinskog fakulteta Rijeka. Svi su studenti zaposleni kao medicinske sestre/tehničari.

Upitnik je osobno ponuđen svim studentima, ispunjavali su ga za vrijeme nastave i njih 110 pristalo je sudjelovati u istraživanju, što čini $85 \%$ ukupnog broja. Odaziv je po godinama studija bio nejednak, što se vidi u tablici $1\left(\chi^{2}=33,4 ; p<0,001\right)$. Neki upitnici nisu bili u potpunosti ispunjeni, tako da smo na kraju imali uzorak od 94 studenta.

Žena je bilo $85 \%$, što odgovara rodnom omjeru na studiju. Muških je ispitanika bilo devet na trećoj godini, pet na drugoj te nijedan na prvoj godini studija $\left(\chi^{2}=6,53\right.$; $p=0,038)$. Ovakva razlika odgovara izvornoj populaciji (jedan muškarac na prvoj godini, sedam na drugoj i deset na trećoj).

Dob ispitanika bila je u rasponu od 22 do 54 godine, prosječna dob 32,0 godina i medijan 33 godine. Ispitanici prve godine mlađi su od studenata druge i treće godine $(t=3,278 ; p=0,001)$ (tablica 2). Nije bilo razlike $u$ dobi po spolu.

\section{Instrument}

Za mjerenje stigme primijenjen je upitnik kojim je već u ranijim istraživanjima utvrđivana stigma prema psihičkim bolestima (Arbanas 2005) ${ }^{15}$. Ovaj upitnik sadrži 15 izjava na temelju kojih su ispitanici ocjenjivali svoj stav prema psihičkoj bolesti (npr. „Mislim da osobe oboljele od PTSP-a ne mogu dobro obavljati svoj posao.“ ili „Da iznajmljujem stan, vjerojatno ga ne bih iznajmio osobi oboljeloj od PTSP-a.“). Uz svaku od izjava ocjenjivao se stav po Likertovoj ljestvici, tj. 0 - potpuno se slažem, 1 - slažem se, 2 - niti se slažem, niti se ne slažem, 3 - ne slažem se i 4 - uopće se ne slažem. Za izračunavanje stigmatizacije zbrojene su vrijednosti pojedinih čestica (tj. inverzne vrijednosti, $4-x$, u slučaju čestica slaganje $s$ kojima se ukazuje na manju stigmu - kao što su čestice u primjeru).

Da bi se usporedila stigma prema depresiji i shizofreniji, uz čestice koje opisuju odnos prema oboljelima od PTSP-a dodane su istovjetne čestice za depresiju i shizofreniju. Na ovakav je način ukupno dobiveno 45 čestica. $\mathrm{U}$ upitniku su bile navedene slučajnim redoslijedom.

\begin{tabular}{|c|c|c|c|}
\hline \multicolumn{4}{|c|}{ Tablica 1. Odaziv studenata sestrinstva (po godinama studija) } \\
na ispitivanje stigme prema psihičkim bolestima
\end{tabular}

\begin{tabular}{|c|c|c|c|}
\hline \multicolumn{4}{|c|}{ Tablica 2. Dob ispitanika po godinama studija } \\
\hline & godina & godina & godina \\
\hline Dob ispitanika $(g)$ & $28,71 \pm 5,26$ & $34,00 \pm 6,65$ & $32,37 \pm 4,98$ \\
\hline
\end{tabular}


Upitnik je bio anoniman, a ispunjavanje dobrovoljno. Od demografskih se podataka od ispitanika tražilo da navedu svoj spol, dob i godinu studija.

\section{Rezultati}

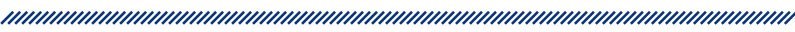

Na slici 1 prikazani su rezultati istraživanja povezani sa stigmatizacijom po spolu i po dijagnozama. Jasno se vidi da je i kod žena i kod muškaraca stigma prema shizofreniji značajno veća nego stigma prema depresiji i PTSP-u $(p<0,001)$. S druge strane, nije bilo razlike između stigme prema depresiji i PTSP-u. Muškarci i žene nisu se razlikovali po stigmi prema depresiji i PTSP-u, no žene su bile više stigmatizirajuće prema oboljelima od shizofrenije $(p=0,036)$.

Nije bilo razlike u stigmatizaciji prema godini studija, uz izuzetak da su studenti prve godine više stigmatizirali osobe s PTSP-om nego studenti druge i treće godine $(\mathrm{t}=$ 2,194; $p=0,033$ ) (slika 2).

Ispitanici stariji od 36 godina imali su više stigmatizirajuće stavove prema shizofrenim ( $p<0,001)$ i depresivnim osobama $(p=0,044)$, dok je za PTSP postojala samo tendencija tome $(p=0,076)$ (slika 3).

\section{Rasprava}

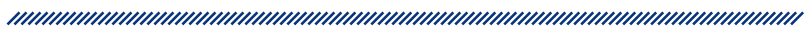

Medicinske sestre i tehničari doživljavaju se među ljudima kao oni koji su u zdravstvu u vrhu po pitanju etičnosti $\mathrm{i}$ iskrenosti ${ }^{16}$. Oni su prvi u kontaktu s bolesnikom i imaju važnu ulogu u mjerama postupanja prema osobama oboljelima od psihičkih bolesti. Tijekom njihove edukacije i školovanja moguće je djelovanje na znanja i stavove pa time i na stigmatizaciju prema psihičkim bolestima ${ }^{17}$.

Među našim studentima sestrinstva odaziv je bio najveći na trećoj godini studija. Ovo je vjerojatno posljedica činjenice da na trećoj godini slušaju kolegij Psihijatrija, a istraživači sudjeluju u izvođenju ovog kolegija te vjerojatno oni s prve i druge godine nisu bili tako motivirani za sudjelovanje (premda je sudjelovanje bilo anonimno).

Većina su studenata žene (85 \%), što odgovara situaciji u zdravstvu, a posebice sestrinstvu.

Rezultati su pokazali da je stigma prema shizofreniji značajnija i veća od one prema depresiji i PTSP-u. Ovakav je odnos shizofrenije i depresije očekivan, jer većina istraživanja pokazuje da su ljudi (uključujući i zdravstvene djelatnike) negativnijeg stajališta prema shizofreniji nego prema depresiji te da se često boje shizofrenih bolesnika i doživljavaju ih kao opasne. Za razliku od toga, depresivne uglavnom doživljavaju kao one kojima se može pomoći i koji nisu krivi za svoje stanje ${ }^{18}$.

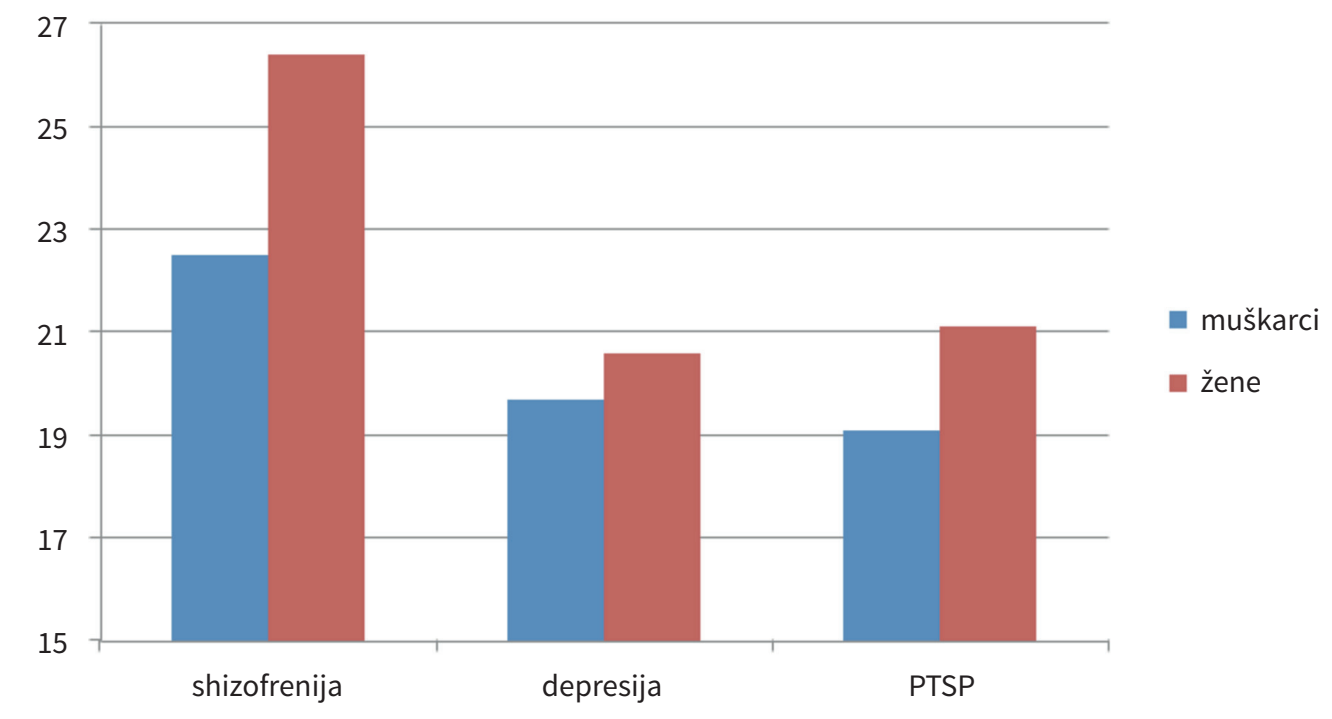


Prema rezultatima naši studenti i studentice nisu pokazali stigmu prema PTSP-u veću od one prema depresiji. Naime, istraživanja medija pokazuju da je stav prema PTSP-u u medijima uglavnom negativan te da se ova bolest prikazuje na senzacionalistički i stigmatizirajući način ${ }^{3}$. Kako vrijeme od Domovinskog rata odmiče, tako se PTSP prikazuje u sve negativnijem kontekstu, s pora- stom broja članaka u crnoj kronici, a smanjenjem u rubrikama o godišnjicama i sjećanjima. Po spolu nije bilo razlike u stigmatizaciji prema depresiji i PTSP-u, a prema shizofreniji su bile više stigmatizirajuće žene. Većina istraživanja pokazuje da su žene manje stigmatizirajuće nego muškarci (u općoj populaciji) ${ }^{6,19}$. Među zdravstvenim se djelatnicima ta razlika smanjuje ${ }^{14}$ vjerojatno

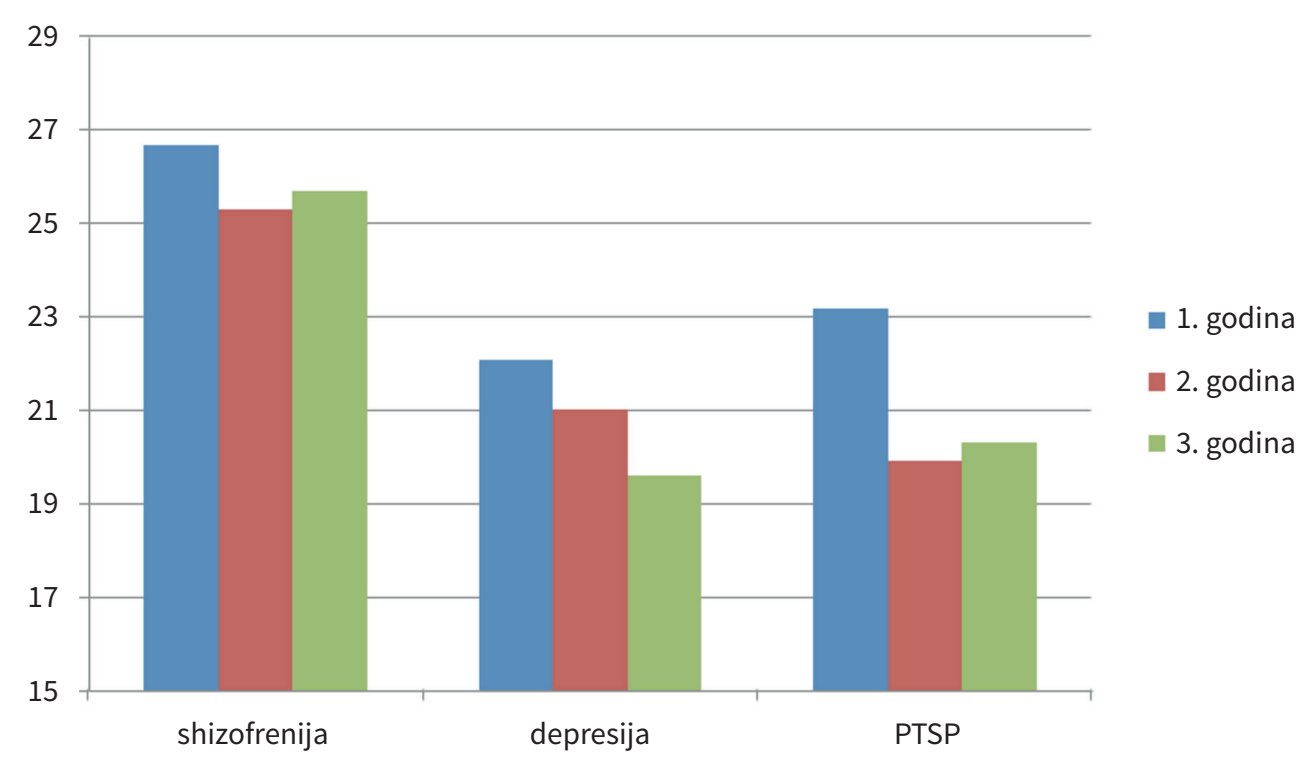

Slika 2. Stigmatiziranje prema psihičkim bolestima, ovisno o godini studija

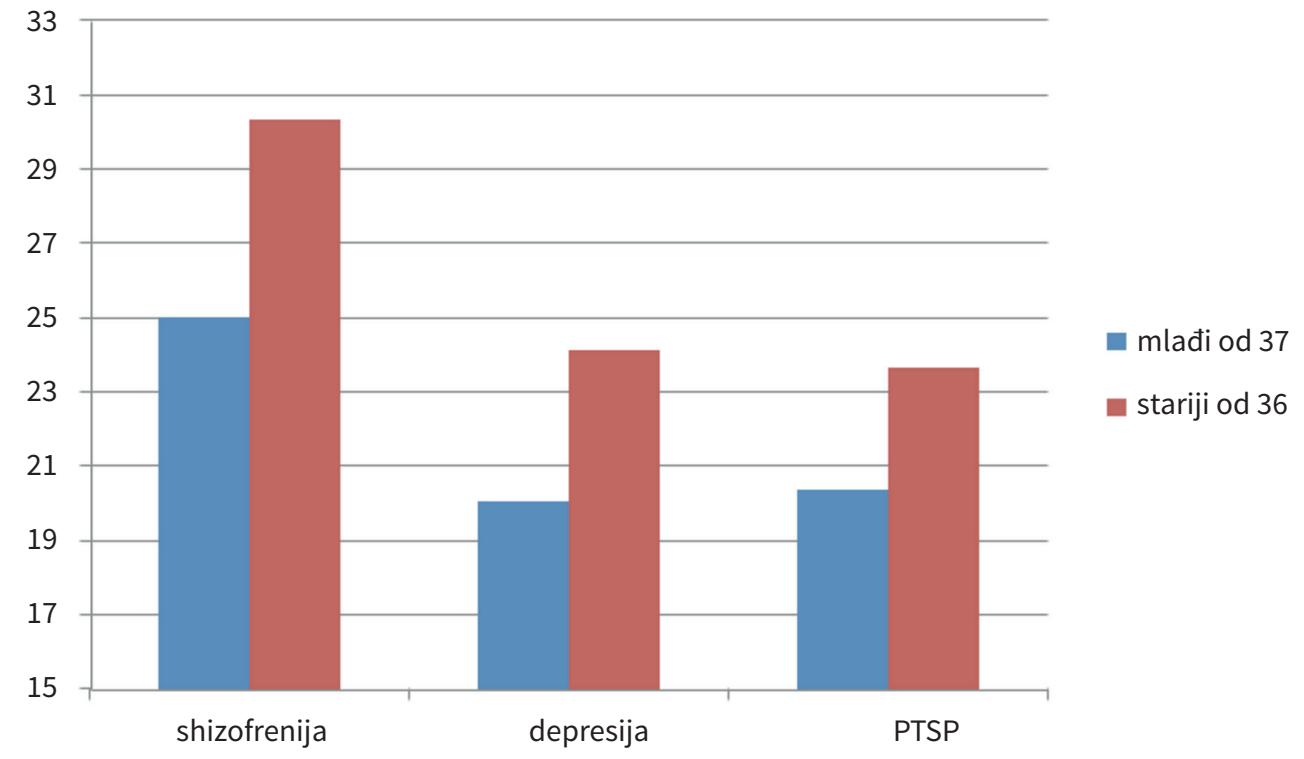


zbog kontakata s bolesnicima i povećanog znanja o psihičkim bolestima, no nismo našli nijedan rad u kojemu su žene pokazivale veću stigmu od muškaraca, tj. u kojem je došlo do inverzije u odnosu na opću populaciju. Moguća objašnjenja mogla bi biti da su u našem uzorku muškarci češće imali nekog člana obitelji oboljelog od shizofrenije ili da su češće radili na psihijatriji i dolazili u kontakt s oboljelima od shizofrenije (na psihijatrijskim odjelima u Hrvatskoj u većini se slučajeva zapošljavaju muškarci), no ovo nismo ispitivali u upitniku.

Po godinama studija nije bilo razlike u stigmatizaciji prema depresiji i shizofreniji, dok su studenti prve godine više stigmatizirali oboljele od PTSP-a u odnosu na one na višim godinama. Očekivali bismo da će studenti na višim godinama (osobito na trećoj, na kojoj se sluša kolegij psihijatrije) biti manje stigmatizirajući. Smatramo da je razlog za odsutnost ovog smanjenja stigme po godinama studija taj što je u konkretnom uzorku riječ o studiju uz rad, tako da svi studenti imaju godine sestrinskog staža i ne razlikuju se po iskustvu. Vjerojatno su svi studenti tijekom svojeg rada dolazili u kontakt s osobama s psihičkim bolestima i sam studij neće značajno pridonijeti kontaktu s ovim bolesnicima, što u drugim uvjetima studiranja može biti važan čimbenik koji utječe na smanjenje stigme (npr. Halter 2004) ${ }^{17}$.

Stariji studenti bili su više stigmatizirajući prema shizofreniji i depresiji nego mlađi. Ovo je u suglasju s nekim drugim istraživanjima koja pokazuju da mlađe osobe i osobe liberalnijih stavova imaju manju stigmatizaciju od starijih i konzervativnijih (Halter 2004) ${ }^{17}$, premda ima i istraživanja koja pokazuju da osobe koje duže rade u zdravstvu (pa su time i starije) imaju manju stigmu. Budući da u našem istraživanju nije bilo velike razlike u dobi između studenata 1., 2. i 3. godine, vjerojatno je ova razlika u stigmi po dobi odraz učinka dobi, a ne godina staža.

Dakle rezultati ovog rada govore u prilog tome da studenti i studentice sestrinstva, unatoč stalno prisutnom negativnom pisanju u dnevnim i tjednim novinama o oboljelima od PTSP-a, nisu preuzeli ovakav stav te ne stigmatiziraju osobe oboljele od PTSP-a ništa više nego oboljele od depresije.

\section{Zaključak}

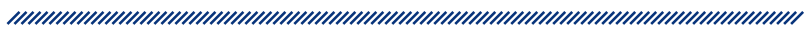

Stigma koja je predstavljena negativnim obilježavanjem osoba samo zato što imaju dijagnozu psihičkog poremećaja danas je veliki društveni, medicinski i etički problem. Usprkos napretku u liječenju osoba s mentalnim poremećajem i pomaku prema liječenju u zajednici, stigma negativno utječe na traženje pomoći, prihvaćanje liječenja, uspješan ishod liječenja, kvalitetu života i integraciju oboljelih u zajednici. Stigma psihičke bolesti vrlo je raširena, ima psihološke, socijalne i ekonomske posljedice za stigmatizirane osobe te narušava ljudska prava oboljelih na poštovanje, ravnopravnost i liječenje. Medicina i psihijatrija kao struka te svi zdravstveni djelatnici moraju razvijati uspješne metode borbe protiv stigme kako bi velikoj skupini ljudi osigurali osnovna ljudska prava. 


\section{Literatura}

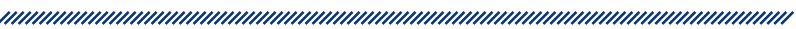

1. Pejović-Milovančević M, Lečić-Toševski D, Tenjović L, Popović-Deušić S, Draganić-Gajić. Changing attitudes of high school students towards peers with mental health problems. Psychiatria Danubina. 2009;21(2):213-219.

2. Frančišković T. Duševni poremećaji i stigma. U: Frančišković T, Moro Lj, ur. Psihijatrija. Zagreb: Medicinska naklada; 2009:254-457.

3. Frančišković $T$, Stevanović $A$, Blažić $D$, Petrić $D$, Šuković Z., Tovilović Z, Moro IN. Croatian war veterans in print media in 1996 and in 2006. Psychiatria Danubina. 2011;23(2):171-177.

4. Šendula Jengić V. Kriminogene specifičnosti psihotičnih počinitelja kaznenih dijela. Doktorska disertacija. Zagreb: Medicinski fakultet; 2008.

5. Crisp AH, Gelder MG, Rix S, Meltzer HI, Rowlands OJ. Stigmatisation of people with mental illnesses. British Journal of Psychiatry. 2000;177:4-7.

6. Filipčić I, Pavičić D, Filipčić A, Hotujac Lj, Begić D, Grubišin J, Đordević V. Attitudes of medical staff towards the psychiatric label „schizophrenic patient" tested by an anti-stigma questionare. Collegium Antropologicum. 2003;27(1):301-307.

7. Lai YM, Hong CP, Chee CY. Stigma of mental illness. Singapore Medical Journal. 2001;42:111-4.

8. Ertugrul A, Ulug B. Perception of stigma among patients with schizoprenia. Social Psychiatry and Psychiatric Epidemiology. 2004;39:73-7.

9. Wahl OF, Harman CR. Family views of stigma. Schizophrenia Bulletin. 1989;15:131-9.

10. Wahl OF. Mental health consumers experience of stigma. Schizophrenia Buletin. 1999;25:467-78.

11. Link BG, Phelan JC, Bresnahan M, Stueve A, Pescosolidu BA. Public conceptions of mental illness: labels, causes, dangerousness and social distance. Americal Journal of Public Health. 1999;89:1328-33.

12. Štrkalj Ivezić S, Jukić V, Hotujac Lj, Kušan Jukić M, Tikvica A. Organizacija zaštite mentalnog zdravlja u zajednici. Liječnički Vjesnik. 2010;132:38-42.

13. Jokić-Begić N, Kamenov Ž, Lauri Korajlija A. Kvalitativno i kvantitativno ispitivanje sadržaja stigme prema psihičkim bolesnicima. Socijalna psihijatrija. 2005;33(1):10-19.

14. Arbanas G. Adolescents' Attitudes toward schizophrenia, depression, and PTSD. Journal of Psychosocial Nursing. 2008;46(3):45-51.

15. Arbanas G. Stavovi maturanata medicinske škole prema shizofreniji, depresiji i posttraumatskom stresnom poremećaju. Socijalna psihijatrija. 2005;33(1):41-46.

16. Gallup Organization. Honesty/etics in professions. 2002.

17. Halter MJ. Stigma and help seeking related to depression: a study of nursing students. Journal of Psychosocial Nursing. 2004;42:42-51.
18. Caldwell TM, Jorm AF. Mental health nurses' beliefs about likely outcomes for people with schizophrenia or depression: a comparison with the public and other healthcare professionals. Australian and New Zealand Journal of Mental Health Nursing. 2001;10:42-54.

19. Lopez LR. Adolescents' attitudes toward mental illness and perceived sources of their attitudes and examination of pilot dana. Archives of Psychiatric Nursing. 1991;5:271-280. 


\section{DO NURSING STUDENTS STIGMATIZE PATIENTS SUFFERING FROM POSTTRAUMATIC STRESS DISORDER?}

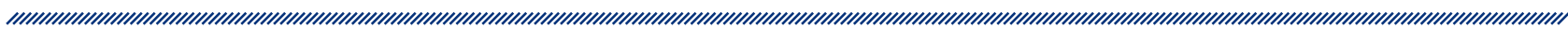

1 Josipa Rožman

1 Goran Arbanas

1 General hospital Karlovac, Department of Psychiatry, Andrije Štampara 3, 47000 Karlovac

\section{Abstract}

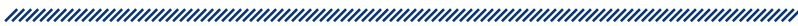

Psychiatric patients, in addition to the difficulties associated with their mental disorder, are faced with difficulties that arise from their stigmatization in the environment in which they live. Discriminating behaviours such as limits on health care, the right to education, various situations related to employment are just some of the examples that can further undermine their physical and psychological health. Stigma leads to low self-esteem and to feelings of isolation, loneliness and discrimination, which further complicates the treatment of the underlying disease.

Stigma often accompanies mental disorders and usually interferes with the treatment and patients' functioning. After the Homeland War in Croatia, there has been a high number of people suffering from posttraumatic stress disorder (PTSD). PTSD is often portrayed negatively in the media.

Participants were 94 nursing students. There were 85\% female participants with the average age of 32 (age range 22 to 54). Stigma toward schizophrenia, depression and PTSD was measured by a questionnaire with
15 items for each of the disorders, with Likert-type responses.

Nursing students showed much higher level of stigma toward schizophrenia, compared to PTSD and depression. Women were more stigmatizing toward schizophrenia than men. Freshmen students were more stigmatizing toward PTSD than sophomores and juniors. Older students (older than 36 ) were more stigmatizing, compared to younger students.

Keywords: stigma, schizophrenia, depression, PTSD, nursing students 


\section{Ewingov sarkom i fizioterapija kao dio medicinskog tretmana $u$ rehabilitaciji onkoloških bolesnika}

1 Hrvoje Gudlin

1 Specijalna bolnica za zaštitu djece s neurorazvojnim i motoričkim smetnjama

\section{Sažetak}

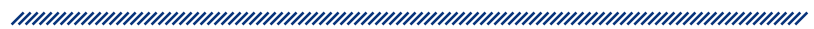

Ewingov sarkom treći je po učestalosti primarni zloćudni tumor kostiju, iza osteosarkoma i hondrosarkoma, te je drugi najčešći zloćudni tumor kostiju kod djece i adolescenata, a čini otprilike 10 do $15 \%$ svih primarnih tumora kostiju. Najčešće je lokaliziran na donjim ekstremitetima (45\%). Slijede zdjelica (20\%), gornji ekstremiteti (13\%), aksijalni skelet i rebra (13\%) te kosti lica, gdje se najrjeđe javlja, u svega $2 \%$ slučajeva. Tumor se razvija u medularnoj šupljini te se širi kroz kost i pokosnicu u meka tkiva. Može biti lokaliziran ili metastazirajući. Tipični su simptomi bol, oteklina, venski crtež, neuroispadi, ograničena pokretljivost, slabost, umor i vrućica. Dijagnostika uključuje rendgensko snimanje, CT, MR, scintigrafiju te biopsiju za postavljanje konačne dijagnoze. Liječenje se sastoji primarno od ciklusa polikemoterapija u trajanju od 12 do 24 tjedana. Nakon toga slijede operacija, radioterapija, kemoradioterapija ili amputacija. Prognoze su za petogodišnje preživljavanje pacijenata s lokaliziranim tumorom oko $70 \%$, a pacijenata s metastazirajućim tumorom oko 20 do $30 \%$. Prognoze su loše kod pacijenata s recidivom tumora, a njih ima oko 30 do $40 \%$. Trećina pacijenata s recidivom tumora ima manje od $20 \%$ šanse da preživi.
U današnje doba javlja se sve veća potreba za fizioterapijom i rehabilitacijom onkoloških bolesnika, kako bi pacijenti ostvarili što veću kvalitetu života. Fizioterapija u tretmanu onkoloških pacijenata započinje već u jedinici intenzivnog liječenja. Kod Ewingova sarkoma fizioterapija ima značajnu ulogu u prijeoperacijskom razdoblju, kao i nakon operacije ili amputacije.

Ključne riječi: Ewingov sarkom, rehabilitacija, fizioterapija, kvaliteta života

Datum primitka: 28.05.2015.

Datum prihvaćanja: 08.09.2015.

\section{Adresa za dopisivanje:}

Hrvoje Gudlin, bacc. physioth.

Specijalna bolnica za zaštitu djece s neurorazvojnim i motoričkim smetnjama

Ivane Brlić-Mažuranić $82 \mathrm{~A}$, Zagreb

Tel.: 0951995910

E-pošta: hrvoje.gudlin@gmail.com

\section{Uvod}

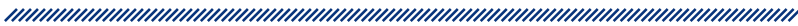

Koštani tumori čine tek $5 \%$ ukupnog broja tumora dječje dobi. Najčešći je osteosarkom, a slijedi Ewingov sarkom $^{1}$. Ewingov sarkom treći je po učestalosti primarni zloćudni tumor kostiju, iza osteosarkoma i hondrosarkoma, te je drugi najčešći zloćudni tumor kostiju kod 
djece i adolescenata, a čini otprilike 10 do $15 \%$ svih primarnih tumora kostiju. Godišnja je incidencija 0,6 na 1000000 ljudi, a obično se javlja između desete i dvadesete godine života. Nešto se češće javlja kod djece muškog spola $(1,5: 1 \text { u odnosu na žensku djecu })^{2,3}$. Bolest nije povezana s okolinskim faktorima, kao ni s naslijeđem, s obzirom na to da se genske promjene događaju nakon rođenja. Isto tako, bolest se ne može prevenirati ${ }^{4}$. Ewingov sarkom najčešće je lokaliziran na donjim ekstremitetima (45\%). Slijede zdjelica (20\%), gornji ekstremiteti $(13 \%)$, aksijalni skelet i rebra (13\%) te kosti lica, gdje se najrjeđe javlja, u svega $2 \%$ slučajeva ${ }^{3}$. Od kostiju najčešće bude zahvaćen femur ${ }^{3,5}$. Obično se pojavi na metafizi duge kosti ili neposredno u blizini metafize, iako može zahvatiti i plosnate kosti (zdjelica, lopatica) ${ }^{6}$. Do bolesti dolazi zbog karakteristične kromosomske translokacije $\mathrm{t}(11 ; 22)$ (q24;q12), koja uzrokuje fuziju gena EWS s genom za transkripcijski čimbenik FLI-1. Taj fuzionirani gen EWS-FLI-1 funkcionira kao onkogen koji stimulira rast tumorskih stanica. Tumor se razvija u medularnoj šupljini te se širi kroz kost i pokosnicu u meka tkiva. Može biti lokaliziran ili metastazirajući. Metastazira hematogeno u pluća, organe, druge kosti te rijetko u limfne čvorove ${ }^{2}$.

\section{Simptomi, klinička slika i dijagnostika}

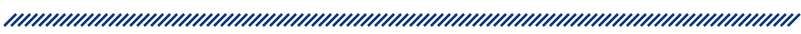

Tipični su simptomi bol, oteklina koja je bolna na pritisak, venski crtež koji, kao i oteklina, ukazuje na ekstraosalni prodor tumora, neuroispadi koji se javljaju u slučaju kompresije živca oko tumora, ograničena pokretljivost ako je tumor u području oko zgloba te slabost, umor i vrućica. Bol se često javlja noću pa remeti san. Bolovi mogu popuštati pa opet jačati, a te se epizode izmjenjuju sa sve kraćim periodima stanki te na kraju nastupi trajno stanje s jakim bolovima ${ }^{1,5,6,7}$. Nad tumorom je koža topla, pacijent često ima povišenu temperaturu, povećana je sedimentacija eritrocita i više je leukocita u krvi .

Točna je dijagnoza ključna za odgovarajuću kliničku skrb oko pacijenta. Određene kliničke informacije su iznimno važne za diferencijaciju Ewingova sarkoma od nekih drugih tumora dječje dobi³. Kreće se s rendgenskim snimanjem suspektnog područja. Tipično se može vidjeti periostalna reakcija u obliku razvoja slojeva nove kosti, što izgledom podsjeća na lukovicu ${ }^{2,5}$. Nakon toga potrebno je učiniti CT i MR zahvaćene kosti tj. područja, CT toraksa kako bi se rano otkrile eventualne metastaze i scintigrafiju kosti te razmotriti potrebu za biopsijom koštane srži. Za definitivno postavljanje dijagnoze Ewingova sarkoma nužno je napraviti biopsiju ${ }^{1,5,8}$.

\section{Mogućnosti liječenja i prognoze}

Tretman onkološkog bolesnika zahtijeva multidisciplinarni pristup koji uključuje suradnju ortopeda, onkologa, plastičnog kirurga, patologa, radiologa, kao i niz ostalih djelatnika medicinske struke ${ }^{7}$. Ključni oblici liječenja u ranom stadiju bolesti uključuju kiruršku intervenciju, kemoterapiju i radioterapiju te rehabilitacijske postupke ${ }^{9}$. Liječenje se sastoji primarno od ciklusa polikemoterapija u trajanju od 12 do 24 tjedana, a svrha im je smanjiti aktivnost malignih stanica i uništiti mikrometastaze te samim time povećati mogućnost izvođenja radikalnoga kirurškog zahvata s negativnim resekcijskim rubom, što znači da je rub resekcije čist od tumorskih stanica. Bolesnici koji odgovore na primarnu terapiju nastavljaju s lokalnim liječenjem, a to uključuje: kirurški zahvat s prijeoperacijskom radioterapijom ili bez nje, definitivnu kemoradioterapiju ili amputaciju, koja se radi ako je tumor vrlo opsežan ili u slučaju infekcije. Primarne opcije kirurške rekonstrukcije uključuju uzimanje autogenoga koštanog transplantata (dio kosti uzet s nekog drugog dijela tijela, a može se i vaskularizirati), koštanog alotransplantata (dio kosti uzet od druge osobe) ili izradu metalne endoproteze ${ }^{10}$. Adjuvantna kemoterapija slijedi nakon kirurškog zahvata neovisno o resekcijskim rubovima. Bolesnici koji ne reagiraju na primarnu terapiju nastavljaju liječenje radioterapijom s kirurškim zahvatom ili bez njega, uz kemoterapiju ${ }^{1,5}$.

Treba znati da tretman pacijenta, kemoterapija i radioterapija, štete i zdravim stanicama, što kasnije može negativno utjecati na mozak te prouzročiti teškoće učenja. Također, mogu se javiti problemi sa sluhom, vidom, teškoće u rastu i razvoju, kao i oštećenje srca i krvožilnog, dišnog i ostalih tjelesnih sustava. Naposljetku, mogu se razviti i drugi karcinomi ${ }^{4}$.

Prognoze su za petogodišnje preživljavanje pacijenata s lokaliziranim tumorom oko $70 \%$, a pacijenata s metastazirajućim tumorom oko 20 do $30 \% \%^{4}$. Upravo zahvaljujući multidisciplinarnom pristupu, tj. kombinaciji ke- 
moterapije s kirurškim postupcima i/ili radioterapijom, stopa petogodišnjeg preživljavanja napredovala je do $60 \%$ i više ${ }^{8}$. Govoreći o prognozama, u obzir se uzimaju veličina tumora, lokacija primarnog tumora, odgovor na kemoterapiju, dob djeteta, a nekad i kirurški zahvat kao dio inicijalnog tretmana ${ }^{4,11}$. Povoljni su prognostički čimbenici distalni smještaj primarnog tumora, normalna vrijednost LDH-a (laktat dehidrogenaza), nepostojanje diseminacije bolesti pri dijagnozi te lokalizirani tumor. Prognoze su loše kod pacijenata s recidivom tumora, a njih ima oko 30 do $40 \%$. Otprilike trećina pacijenata s recidivom tumora imaju manje od $20 \%$ šanse da prežive. Osobito nepovoljne prognoze odnose se na pacijente kojima se bolest ponovno pojavi unutar 24 mjeseca. Davanje jakih i agresivnih terapija kod takvih pacijenata, uključujući visoke doze, može odgoditi, ali ne i prevenirati smrtni ishod ${ }^{12}$.

\section{Fizioterapija u onkologiji}

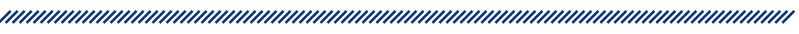

Onkologija (grč. onkos - tumor, logos - znanost) je dio medicine koji se bavi proučavanjem i liječenjem tumora, malignih neoplazmi i temelji se na prevenciji, ranom otkrivanju i pravodobnom liječenju tumora. U suvremeno su doba tumori sve učestaliji, a po smrtnosti su među vodećima ${ }^{13}$.

Liječenje i rehabilitacija onkoloških pacijenata zahtijeva suradnju velikog broja zdravstvenih i socijalnih djelatnika, kao i volontera, obitelji i društva općenito. Proces liječenja i rehabilitacije ne počinje nakon operacije ili u poodmaklom stadiju bolesti. Počinje onog trenutka kad se postavi konačna dijagnoza bolesti. U tom trenutku pacijent, njegova obitelj, zdravstveni tim koji skrbi o njemu te svi oni koji su na bilo koji način povezani s pacijentom i njegovim stanjem kreću u borbu protiv bolesti.

U današnje se doba javlja sve veća potreba za fizioterapijom i rehabilitacijom onkoloških bolesnika, kako bi pacijenti ostvarili što veću kvalitetu života. Rehabilitacija je potrebna u svim fazama liječenja, a najpotrebnija je nakon kirurškog zahvata ${ }^{13}$.

Fizioterapija je dio procesa medicinske rehabilitacije. Omogućuje održavanje, razvijanje i obnovu funkcionalnih sposobnosti liječenih te uspješan povratak u aktivnosti svakodnevnog i profesionalnog života. Fizioterapija kod onkoloških pacijenata uključuje procjenu i prijeoperacijsku pripremu, intervenciju te evaluaciju provedenog, a u tretmanu onkoloških pacijenata započinje već u jedinici intenzivnog liječenja pri provođenju postupaka za uspostavu homeostaze ${ }^{14}$. $U$ jedinici intenzivnog liječenja fizioterapija ima tri osnovna zadatka ${ }^{13}$ :

- vježbama disanja nastoji se brže eliminirati anestetik iz tijela

- pozicioniranjem se nastoji spriječiti nastanak dekubitusa

- pripremiti pacijenta za vertikalizaciju.

Fizioterapija bi trebala pratiti promjene u tehnologiji i znanosti te uz usvajanje vještina i reproduciranje stečenih znanja pridonositi kreativnosti u primjeni ${ }^{15}$. U onkološkom je liječenju fizioterapija vrlo specifična jer se koncentrira na aktivnosti svakodnevnog života, ukupnu kvalitetu života te edukaciju pacijenta i obitelji, a uz to nastoji pružiti podršku bržem oporavku gotovo svih sustava $^{13}{ }^{14}$. Prijeoperacijskom pripremom nastoji se spriječiti i ublažiti odstupanje od fiziološkog te skratiti vrijeme oporavka. Fizioterapeut provodi tehnike respiratorne terapije, nastoji očuvati mobilnost zglobova i mišićnu snagu kroz aktivne, pasivne i asistirane pokrete te educira pacijenta i njegovu obitelj u svrhu poboljšanja kvalitete života ${ }^{1,9,14}$. Ciljevi su poslijeoperacijske fizioterapije i rehabilitacije poboljšanje stanja preostalog zdravlja otkrivanjem čimbenika rizika koji mogu pogoršavati opće stanje i kvalitetu života onkoloških bolesnika, prevencija nastanka komplikacija i onesposobljenja putem radnoterapijskih programa i edukacije, programi podrške u vidu logopedskog tretmana, psihološke podrške te protetičke i ortotičke opskrbe ${ }^{14}$.

U cjelovitom fizioterapijskom procesu onkoloških pacijenata fizioterapeut mora nastojati pružiti maksimum svih onih vještina kojima će na neki način pomoći pacijentu, pripremiti ga na nadolazeće situacije, olakšati mu borbu s bolešću, pomoći mu pri aktivnostima svakodnevice i samozbrinjavanja te mu pružiti fizičku i psihičku potporu. 


\section{Fizioterapija kod osoba s Ewingovim sarkomom}

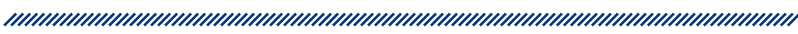

Fizioterapija kod Ewingova sarkoma sa sobom nosi brojne izazove i ne suviše jednostavne situacije. Razlog tomu prvenstveno stoji u činjenici da najviše obolijevaju djeca i mladi, a u rijetkim slučajevima i vrlo mala djeca. Raditi s djecom i mladima lijep je dio fizioterapije, ali isto tako i najteži dio. U teškim situacijama, stanjima povlačenja u sebe, ljutnje, poricanja, depresije i neprihvaćanja novonastale situacije, svaki zdravstveni djelatnik, osim što se drži okvira svoje profesije, trebao bi mladim osobama i djeci biti osoba od povjerenja i podrška u svim aspektima bolesti. Uz djecu, tu su i njihovi roditelji te cjelokupna obitelj. Tretman ovakvih pacijenata stoga nije nimalo jednostavan ni klasičan fizioterapijski tretman.

Jednostavno rečeno, fizioterapijski tretman može se podijeliti na prijeoperacijski i poslijeoperacijski dio. U fazi prijeoperacijske fizioterapije terapeut procjenjuje opće stanje pacijenta, kao i stanje zahvaćenog dijela tijela, na temelju čega planira intervenciju te educira pacijenta i obitelj, kako bi svi bili uključeni u tretman. Važno je pripremiti i jačati zahvaćeni ud, tj. dio tijela na kojemu će se izvršiti kirurški zahvat, pritom izbjegavajući velike težine na zahvaćenom ekstremitetu, održavati aerobni kapacitet, prevenirati eventualne komplikacije i u što boljem stanju dočekati kirurški zahvat ${ }^{14,16}$. Treba imati na umu i strah pacijenta i njegove obitelji te ih $\mathrm{i}$ na tom polju što više pripremiti za nadolazeći zahvat. Poslijeoperacijska fizioterapija nastoji aerobnim vježbama, vježbama jačanja muskulature, aktivnim i pasivnim vježbama za održavanje i postupno povećanje opsega pokreta te, ako postoje uvjeti, vježbama u vodi, kao potpuno drukčijem terapijskom mediju, pomoći pacijentu u oporavku. Nakon zahvata potreban je oprez pri provođenju terapijskih postupaka zbog smanjenog i usporenog tijeka zacjeljivanja nakon kemoterapije ${ }^{9,16}$.

Kod pacijenata kojima je amputiran ud fizioterapija ponovno nudi nove izazove i zadatke. Sama amputacija rezultirat će kraćim boravkom u bolnici te bržim početkom rehabilitacije. Pacijent će biti u mogućnosti uključiti se u razne oblike aktivnosti, doduše, uz ograničenja, ali bit će sposoban izvoditi sve one aktivnosti koje osjeća da može ${ }^{17}$. Svaka osoba gubitak uda doživljava na svoj način, ali svima je zajedničko da se dogodi velika promjena u kratkom vremenskom periodu, kojoj se mo- raju prilagoditi i s kojom moraju živjeti ostatak života. Mladima koji još nisu završili rast bit će otežan razvoj i uspostavljanje normalne posture, biomehanike i ravnoteže. Veliku ulogu u pogledu na amputaciju ima i estetika, pogotovo kod mladih osoba. Može se javiti strah od neprihvaćanja u socijalnu sredinu, kao i manjak samopouzdanja te strah same osobe od uključivanja u društveni život. Zdravstveni tim, obitelj i društvo ovdje moraju pružiti maksimalnu potporu i poticati pacijenta na privikavanje i prihvaćanje situacije. Fizioterapeut ima ulogu educirati pacijenta o novonastaloj situaciji i njezinu utjecaju na svakodnevicu. Također, fizioterapeut i ostali članovi medicinskog tima u obzir moraju uzeti pacijentov osjet, bol, stabilnost, deformitet, snagu, funkcionalnu aktivnost i emocije ${ }^{17}$. Većina pacijenata nakon amputacije mora se naviknuti na nošenje proteze te je tu potrebno uzeti u obzir dug period prilagodbe. Fizioterapeut uči pacijenta pravilno se koristiti protezom i ostalim pomagalima za kretanje, npr. štakama ${ }^{16}$. Važno je da pacijent nauči pravilno aplicirati protezu, pravilno je skinuti, upotrebljavati je u aktivnostima svakodnevnog života kao što su hod, vožnja javnim prijevozom, poslovi u domaćinstvu i sl., kod djece, naravno, igranje s vršnjacima, a tu je fizioterapeut od velike pomoći.

\section{Zaključak}

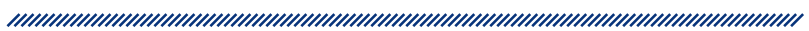

Susret s dijagnozom kao što je Ewingov sarkom ili bilo koji drugi zloćudni tumor uvijek predstavlja veliki šok, stres, tugu i nevjericu. Sama činjenica da je riječ o djetetu ili mladoj osobi daje još veću težinu. Potreba za fizioterapijom kao jednom od metoda medicinskog tretmana onkoloških pacijenata izražena je u sve većoj mjeri. Tretman bez fizioterapije nije cjelovit medicinski tretman jer osoba nema priliku ostvariti punu kvalitetu života, a upravo je to jedan od ciljeva tretmana. Društvo mora izići iz okvira stereotipnih izraza da su onkološki pacijenti oni koji „umiru od raka“ i boriti se skupa s njima za što bolji život i povoljnije posljedice liječenja. Fizioterapija bi kroz pozitivne rezultate tretmana trebala promovirati svoju učinkovitost i svrsishodnost. Medicinski tim mora djelovati kao cjelina u koju svaki član ugrađuje dio znanja, iskustva i vještina, a sve u svrhu što kvalitetnijeg tretmana pacijenta. 


\section{Literatura}

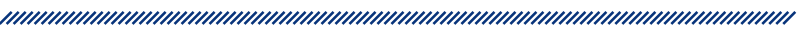

1. Vrcić-Kiseljak Lj, Antolić D, Rašić H. Fizioterapija u liječenju oboljelih od tumora. Skripta za internu upotrebu studenata Zdravstvenog veleučilišta. Zagreb; 2007.

2. Damjanov I, Jukić S, Nola M. Patologija. Zagreb: Medicinska naklada; 2011.

3. Burchill SA. Ewing's sarcoma: diagnostic, prognostic, and therapeutic implications of molecular abnormalities. Journal of Clinical Pathology. 2003;56:96-102.

4. Ewing's sarcoma [Internet]. Dostupno na: www.webmd. com/cancer/ewings-sarcoma? (pristupljeno 24.05.2015.)

5. Vrdoljak E, Šamija M, Kusić Z, Petković M, Gugić D, Krajina Z. Klinička onkologija. Zagreb: Medicinska naklada; 2013.

6. Medicinska enciklopedija, svezak 2. Zagreb: Jugoslavenski leksikografski zavod; 1967.

7. Mavrogenis AF, Ruggieri P. Therapeutic approaches for bone sarcomas. U: Heymann D. Bone Cancer: Primary Bone Cancers and Bone Metastases. Academic Press; 2015.

8. Paulussen $M$, Bielack $S$, Jürgens $H$, Casali PG, ESMO Guidelines Working Group.. Ewing's sarcoma of the bone: ESMO clinical recommendations for diagnosis, treatment and follow-up. Annals of Oncology. 2009;20 Suppl 4:140-142.

9. Dincer F, Dincer M, Baskaya MK. Results of the combined treatment of paediatric intraspinal tumours. Paraplegia 1992;30(10);718-728.

10. Bernstein M, Kovar H, Paulussen M, Randall LR, Schuck A, Teot LA, Juergens H. Ewing's sarcoma family of tumors: Current management. Oncologist. 2006;11(5):503-519.

11. Pritchard D, Dahlin D, Dauphine R, Taylor W, Beabout J. Ewing's sarcoma - a clinicopathological and statistical analysis of patients surviving five years or longer. Journal of bone and joint surgery. 1975;57(1):10-6.

12. Cotterill SJ, Ahrens S, Paulussen M, Jürgens HF, Voûte PA, Gadner H, Craft AW. Prognostic factors in Ewing's tumor of bone: Analysis of 975 patients from the European Intergroup Cooperative Ewing's Sarcoma Study Group. Journal of Clinical Oncology. 2000;18(17):3108-3114.

13. Milas I, Vrcić - Kiseljak Lj. Liječenje i rehabilitacija u onkologiji. U: Vrcić - Kiseljak Lj. i sur. Fizioterapija u onkološkom liječenju i rehabilitaciji - odabrane teme. Zagreb: Medicinska naklada; 2014.

14. Kiseljak D, Vrcić - Kiseljak Lj. Fizioterapija u onkološkoj rehabilitaciji. U: Vrcić-Kiseljak Lj. i sur. Fizioterapija u onkološkom liječenju i rehabilitaciji - odabrane teme. Zagreb: Medicinska naklada; 2014.

15. Vrcić - Kiseljak Lj. i sur. Fizioterapija u onkološkom liječenju i rehabilitaciji - odabrane teme. Zagreb: Medicinska naklada; 2014
16. Ewing's Sarcoma. Physical Therapy Management (current best evidence) [Internet]. Dostupno na: www. physio-pedia.com/Ewing's_Sarcoma\#Physical_Therapy_Management_.28current_best_evidence.29 (pristupljeno 24.05.2015.)

17. Craft AW. Prosthetic replacement surgery for bone tumours - cure at less cost? British Journal of Cancer. 1991;63(2):173-175. 


\section{EWING'S SARCOMA AND PHYSIOTHERAPY AS A PART OF MEDICAL TREATMENT IN THE REHABILITATION OF ONCOLOGICAL PATIENTS}

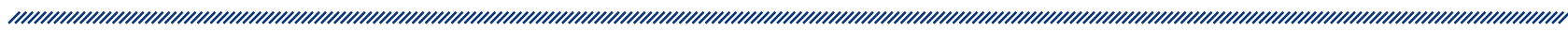

1 Hrvoje Gudlin

1 Special hospital for children with neurodevelopmental disorders

\section{Abstract}

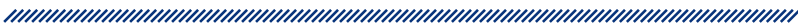

Ewing's sarcoma is the third most common primary malignant bone tumor, following osteosarcoma and chondrosarcoma, it is also the second most common malignant bone tumor in children and adolescents, and makes up about 10 to $15 \%$ of all primary bone tumors. In most cases, it is localized in the lower extremities $(45 \%)$, followed by the pelvic region (20\%), the upper extremities (13\%), the axial skeleton and the ribs (13\%) and the face skeleton (2\%). The tumor arises in the medullary cavity and spreads through the bone and periosteum to soft tissues. It can be localized or metastatic. Typical simptoms are pain, swelling, telangiectasias, neurological deficits, limited mobility, weakness, tiredness and fever. Diagnostics includes X-ray scanning, CT, $M R I$, scintigraphy and, for the final diagnosis, biopsy. The treatment consists primarily of polychemotherapy cycles lasting 12-24 weeks, followed by surgery, radiotherapy, chemoradiotherapy or amputation. The 5-year survival rate of patients with localized tumor is about $70 \%$ and with metastatic tumor it is about $20-30 \%$. The prognosis is poor for patients with tumor relapse which occurs in $30-40 \%$ of the patients. About $30 \%$ of the patients with tumor relapse have less than $20 \%$ chance of survival. Nowadays, there is a growing need for physiotherapy and rehabilitation in the treatment of oncological patients, to help them to achieve the highest possible quality of life. Physiotherapy in the treatment of oncological patients starts in the intensive care unit. Physiotherapy in Ewing's sarcoma treatment plays an important role in the preoperative, postoperative and postamputation period.

Keywords: Ewing's sarcoma, rehabilitation, physiotherapy, quality of life 


\section{Stilovi sučeljavanja sa stresom u odnosu na različite dijagnoze psihičkih poremećaja}

1 Zlata Pjević

1 Slađana Štrkalj Ivezić

2 Anja Melada

1 Klinika za psihijatriju Vrapče

2 Klinika za psihijatriju, Klinička bolnica Dubrava

\section{Sažetak}

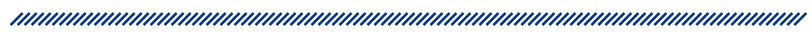

Uvod: Stres je jedan od najčešćih pokretača procesa koji dovode do psihičkih poremećaja. Cilj je istraživanja bio utvrditi postoje li razlike u stilu sučeljavanja sa stresom između sudionika s psihičkim poremećajima u odnosu na zdravu populaciju te razlike u stilovima sučeljavanja između sudionika s mentalnim poremećajima s obzirom na demografske karakteristike. Metode: Sudionici: $\mathrm{U}$ istraživanju je sudjelovalo 120 sudionika podijeljenih u četiri skupine od 30 sudionika. Sudionici s dijagnozom psihičke bolesti bili su podijeljeni u tri skupine: sudionici s depresivnim poremećajem, anksioznim poremećajem i psihotičnim poremećajem te prema spolu, stupnju obrazovanja, dobi, radnom i bračnom statusu, dužini liječenja i broju hospitalizacija. Četvrtu su skupinu činili zdravi sudionici. Instrumenti: Primijenjena je adaptirana verzija dispozicijskog oblika upitnika COPE (Coping Orientation to Problems Experienced). Rezultati: Između skupina oboljelih od psihičke bolesti i zdravih u stilovima sučeljavanja pokazala se statistički značajna razlika u: pozitivnoj interpretaciji, negiranju, ponašajnom dezangažmanu, alkoholu, fizičkoj izolaciji i potiskivanju emocija te razlike u odnosu na spol, dob, bračni status, zanimanje i zaposlenje. Rasprava: Razlike u sučeljavanju kod oboljelih od psihičkih poremećaja nisu određene njihovom psihopatologijom, što je u skladu s istraživanjima drugih istraživača. Sudionici u istraživanju prošli su ili je bilo u tijeku liječenje u dnevnoj bolnici gdje se primjenjuju psihosocijalne metode liječenja, što je moglo utjecati na njihove stilove sučeljavanja. Zaključak: Rezultati istraživanja potvrđuju da se zdrave osobe koriste funkcionalnijim stilovima sučeljavanja u odnosu na oboljele od psihičkih poremećaja. Nismo pronašli specifične stilove sučeljavanja u odnosu na pojedine dijagnostičke skupine, što govori u prilog podatcima da sučeljavanje ovisi o brojnim faktorima.

Ključne riječi: stres, sučeljavanje sa stresom, stil sučeljavanja, psihobiosocijalni model, psihosocijalne intervencije

Datum primitka: 09.06.2015.

Datum prihvaćanja: 08.09.2015.

\section{Adresa za dopisivanje:}

Zlata Pjević, dipl. med. techn.

Zavod za socijalnu psihijatriju, Klinika za psihijatriju Vrapče Bolnička 32, 10000 Zagreb

E-pošta: zlata.pjevic@bolnica-vrapce.hr 


\section{Uvod}

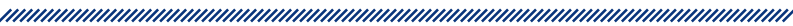

Psihički poremećaji najčešće nastaju interakcijom između bioloških, psiholoških i socijalnih faktora, a stres je jedan od najčešćih pokretača procesa koji dovode do simptoma psihičkog poremećaja te je i primarni uzročnik određenih psihičkih poremećaja.

Stilovi sučeljavanja sa stresom mogu se grupirati prema dva temeljna kriterija: vrsta reakcije (kognitivne/bihevioralne, aktivne/pasivne) i funkcija odnosno svrha pojedinog stila sučeljavanja (približavanje/izbjegavanje, sučeljavanje usmjereno na problem/emocije odnosno na uzrok/simptome) ${ }^{1}$. Lazarusova je podjela na stilove sučeljavanja usmjerene na problem i emocije najčešći način podjele ovih stilova u odnosu na njihovu funkciju. Istraživanja pokazuju da se u stresnim situacijama najčešće primjenjuju obje skupine stilova sučeljavanja ${ }^{2}$. Endler i Parker $(1990)^{3}$ identificirali su i treći stil sučeljavanja koji se naziva sučeljavanje izbjegavanjem, a odnosi se na kognitivne, emocionalne ili ponašajne pokušaje udaljavanja od izvora stresa ili od psihičkih i tjelesnih reakcija na stresor.

Odgovor na stres može biti pod utjecajem mnogih varijabli, procjena stresora spregnuta je sa sposobnostima pojedinca da se suoči s izazovom, što predstavlja djelomično značajan faktor u određivanju bihevioralnog i biološkog ishoda ${ }^{2,4,5}$. Određeni stilovi sučeljavanja prevladavaju u određenim patološkim stanjima. U depresivnim poremećajima prevladava emocijski fokusirano sučeljavanje, djelomično emocionalno sadržavanje ${ }^{6,7,8}$ te ruminacija ${ }^{9}$ uz smanjeno korištenje kognitivnim restrukturiranjem ${ }^{7}$ i traženjem podrške okoline ${ }^{10,11}$. Prema nekim studijama, uspoređujući stilove sučeljavanja osoba s depresivnim poremećajem i zdravih osoba pokazalo se da se osobe s depresivnim poremećajem češće koriste emocionalnim ventiliranjem, maštanjem, izbjegavanjem i traženjem emocionalne podrške, a manje su se koristile sučeljavanjem prema rješavanju problema $^{12,13}$. Pacijenti s anksioznim poremećajem u komorbiditetu s kardiovaskularnim bolestima također se koriste maladaptivnim stilovima sučeljavanja kao što su izolacija, inhibicija i somatizacija ${ }^{14}$. Istraživanja na području depresije i anksioznih poremećaja upućuju na češću primjenu izbjegavanja, kao i stilova sučeljavanja orijentiranih prema emocijama u odnosu na sučeljavanje orijentirano na rješavanje problema. Pacijenti sa shizofrenijom koriste se slabije prilagođenim meha- nizmima ${ }^{15} \mathrm{~s}$ obzirom na smanjeni kortizonski odgovor na psihosocijalni stres ${ }^{16}$, a prema naturalističkoj studiji praćenja oboljelih od shizofrenije, kvaliteta života više je povezana sa sučeljavanjem sa stresom nego sa samom psihopatologijom ${ }^{17}$. U istraživanju Vrdoljaka o socijalnom funkcioniranju osoba s dijagnozom shizofrenije u odnosu na načine sučeljavanja sa stresom vidljivo je da se osobe koje imaju manja oštećenja socijalnog funkcioniranja koriste povoljnijim načinima sučeljavanja u stresnoj situaciji ${ }^{18}$.

U razumijevanju svih psihičkih poremećaja kontekst psihobiosocijalnog modela koji uključuje teoriju osjetljivosti na stres ${ }^{19,20,21}$ objašnjava biološke predispozicije za psihičke poremećaje, stresore iz okoline i vulnerabilnost osobe. Psihosocijalne intervencije pomažu da se negativni efekti stresa ublaže i na taj način predstavljaju protektivne faktore jer povećavaju sučeljavanje i kompetenciju koji štite osobu od negativnih utjecaja stresnih događaja. Na bilo kojoj razini patologije uspješno sučeljavanje može značajno smanjiti socijalno i radno oštećenje te oštećenje brige o sebi22.

Cilj je istraživanja bio utvrditi postoje li statistički značajne razlike u stilu sučeljavanja sa stresom između sudionika s mentalnim poremećajima u odnosu na zdravu populaciju te između sudionika s mentalnim poremećajima u odnosu na stilove sučeljavanja sa stresom s obzirom na sljedeće parametre: spol, starost, bračni status, stručnu spremu (zanimanje), zaposlenost, dijagnozu, dužinu liječenja i broj hospitalizacija. Prepoznavanje razlika u sučeljavanjima omogućuje nam i bolje planiranje i tijek liječenja.

\section{Metode}

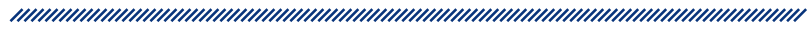

\section{Sudionici}

Ispitivanje je provedeno individualno $\mathrm{u}$ periodu od veljače do lipnja 2012. godine u Klinici za psihijatriju Vrapče. Za potrebe ispitivanja zatraženo je odobrenje Etičkog povjerenstva Klinike za psihijatriju Vrapče, koje je i dobiveno uz obrazloženje da se uz svaki upitnik priloži Informirani pristanak za svakog sudionika te Suglasnost za sudjelovanje. Sudionici su bili pacijenti koji su dolazili na ambulantno liječenje Zavoda za so- 
cijalnu psihijatriju u sklopu programa Dnevne bolnice, Odjela za rehabilitaciju u zajednici te Odjela za neuroze i granična stanja, a kontrolnu su skupinu činile osobe koje nemaju dijagnosticiran psihički poremećaj (zdrava populacija), odnosno medicinske sestre na trećoj godini izvanrednoga stručnog studija sestrinstva pri Zdravstvenom veleučilištu u Zagrebu koje su pohađale kolegij Zdravstvena njega psihijatrijskog bolesnika u Klinici za psihijatriju Vrapče. Ispitivač se prvo predstavio i ukratko objasnio da će ovo istraživanje poslužiti za izradu rada te da se njime ispituje kako se ljudi najčešće nose sa stresom prilikom rješavanja svakodnevnih problema. Sudionici su zamoljeni da na pitanja odgovore iskreno, uz napomenu da je ispitivanje anonimno i da će se rezultati upotrebljavati isključivo u svrhu istraživanja, odnosno za statističku obradu. Sudionicima je naglašeno da njihove upitnike neće vidjeti nitko drugi osim ispitivača. Sudionici su zamoljeni za suradnju, ali im je također naglašeno da mogu odbiti sudjelovanje i odustati kada god to žele. Na odjelu za liječenje neuroza i graničnih stanja deset ispitanika (uglavnom $\mathrm{s}$ dijagnozom PTSP-a) odbilo je ispunjavanje upitnika, a na Odjelu za rehabilitaciju u zajednici četiri su upitnika bila neadekvatno popunjena, i to kod ispitanika s dijagnozom shizofrenije. Svaki je upitnik imao svoju detaljnu uputu te su se ispitanici mogli obratiti ispitivaču u slučaju da je bilo potrebe za dodatnim objašnjenjem. Primjena upitnika trajala je oko 30 minuta. Ispitivanje komparabilne skupine osoba koje nemaju dijagnosticirani psihički poremećaj (zdrava populacija) provedeno je u malim grupama za vrijeme obavljanja vježbi u Klinici za psihijatriju Vrapče u sklopu kolegija Zdravstvena njega psihijatrijskog bolesnika.

$\mathrm{U}$ ispitivanju je sudjelovalo ukupno 120 sudionika podijeljenih u četiri skupine, od kojih su tri skupine sudionici s dijagnozom psihičke bolesti, a jednu skupinu od 30 sudionika činila je zdrava populacija (nemaju dijagnozu psihičke bolesti). Sudionici s dijagnozom psihičke bolesti bili su podijeljeni u tri skupine od 30 sudionika ( $\mathrm{N}=30$ ): osobe liječene od depresije, anksioznih poremećaja i psihotičnih poremećaja. Sudionici u tim skupinama dijagnostički su klasificirani prema Međunarodnoj klasifikaciji bolesti (MKB-10). U skupini ispitanika s depresivnim poremećajem bile su zastupljene dijagnoze: F32.1 (umjerena depresivna epizoda), F32.2 (teška depresivna epizoda bez psihotičnih simptoma), F33.1 (ponavljajući depresivni poremećaj, sadašnja epizoda umjerena) i F33.2 (ponavljajući depresivni poremećaj, sadašnja epizoda teška). U skupini sudionika s anksioznim poremećajem bile su zastupljene dija- gnoze: F40 (fobični anksiozni poremećaji), F41 (drugi anksiozni poremećaji), F43.0 (akutna reakcija na stres), F43.1 (posttraumatski stresni poremećaj) i F43.2 (poremećaj prilagodbe). U skupini s psihotičnim poremećajem su sudionici imali dijagnoze: F20.0 (paranoidna shizofrenija) i F25 (shizoafektivni poremećaj), dok su sva sudionika bila s dijagnozom F22 (perzistirajući sumanuti poremećaj) te dvije osobe s F23 (akutni prolazni psihotični poremećaj). Sudionike smo podijelili i prema spolu, stupnju obrazovanja, dobi, radnom i bračnom statusu (tablica 1) te dužini liječenja u mjesecima (tablica 2) i broju hospitalizacija (tablica 3). U skupini sudionika s anksioznim poremećajem bilo je dva puta više muškaraca, a u skupini zdrave populacije natpolovičnu su većinu činile žene. Što se tiče obrazovanja, najveći je udio sudionika bio sa završenom srednjom školom. U skupinama osoba s psihičkim poremećajem najmlađa je dob sudionika bila iz skupine osoba s psihotičnim poremećajem (prosjek 42 godine), dok je donja granica kod osoba s depresijom 41 do 63 godine (prosjek 51 godina). Najmlađi je sudionik bio iz skupine anksioznih bolesnika. Najveći prosjek liječenja imali su sudionici iz skupine osoba s psihotičnim poremećajem (13 godina) što je povezano i s vrlo ranim početkom bolesti. U broju hospitalizacija bilo je evidentirano samo bolničko liječenje, dok se liječenje u Dnevnoj bolnici tretiralo kao ambulantno liječenje. Većina sudionika s psihotičnim poremećajem bila je hospitalizirana u slučaju pogoršanja bolesti, dok se većina depresivnih sudionika liječila kroz programe Dnevne bolnice. U skupinama bolesne populacije najveći je broj zaposlenih bio s depresivnim poremećajem (63,3\%), dok je najveći broj nezaposlenih bio iz skupine osoba s psihozom (36,7 \%). Najviše umirovljenika bilo je u skupini anksioznog poremećaja (53\%). Najveći je broj sudionika koji živi u bračnoj zajednici bio u skupini sudionika koji imaju depresivni poremećaj (90\%), dok je u skupini sudionika s psihozom većina neoženjena $(66,7 \%)$.

\section{Instrumenti}

$U$ ispitivanju stilova sučeljavanja sa stresnim situacijama primijenjena je adaptirana verzija upitnika COPE (Coping Orientation to Problems Experienced). Autori su ovog upitnika Carver, Weintraub i Scheirer (1989) ${ }^{23}$. Adaptaciju upitnika za naše kulturalne uvjete napravili su autori Hudek-Knežević i Kardum (1993) ${ }^{24}$. Ovako adaptirani upitnik COPE sastoji se od 71 čestice koje čine 17 empirijski deriviranih skala, od kojih je 15 preuzeto iz izvornog (COPE) upitnika, dok specifični odgovori sudionika našeg područja sačinjavaju dvije dodatne 
Tablica 1. Podjela sudionika prema spolu, dobi, prosječnoj dobi, stupnju obrazovanja, radnom i bračnom statusu

\begin{tabular}{|c|c|c|c|c|c|c|c|}
\hline 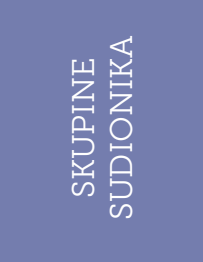 & 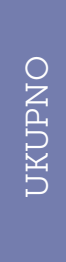 & $\begin{array}{l}\stackrel{1}{\circ} \\
\stackrel{n_{1}}{1}\end{array}$ & $\stackrel{m}{\circ}$ & 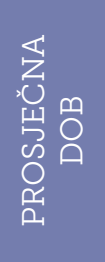 & 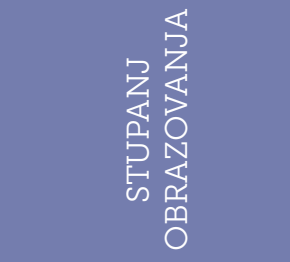 & 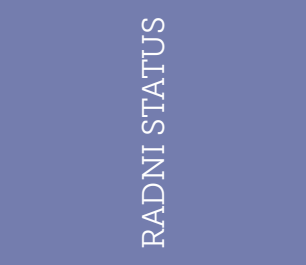 & 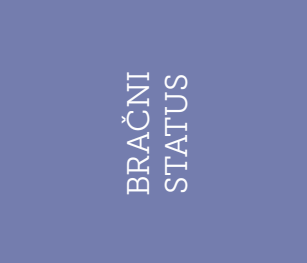 \\
\hline $\begin{array}{l}\text { OSOBE S } \\
\text { DEPRESIVNIM } \\
\text { POREMEĆAJEM }\end{array}$ & 30 & $\begin{array}{l}M-13(43,3 \%) \\
\grave{Z}-17(56,7 \%)\end{array}$ & $41-63$ & 51 god. & $\begin{aligned} \text { - OSNOVNA ŠKOLA: } 4 \\
\text { (13,3 \%) } \\
\text { - SREDNJA STRUČNA } \\
\text { SPREMA: } 23(76,7 \%) \\
\text { - VIŠA STRUČNA } \\
\text { SPREMA: } 1(3,3 \%) \\
\text { - VISOKA STRUČNA } \\
\text { SPREMA: } 2(6,7 \%)\end{aligned}$ & $\begin{aligned} & \text { ZAPOSLEN/A: } 19 \\
& (63,3 \%) \\
\text { - } & \text { NEZAPOSLEN/A: } \\
& 7(23,3 \%) \\
\text { - } & \text { U MIROVINI: } 4(13,3 \%) \\
\text { - } & \text { DRUGO: } 0(0,00 \%)\end{aligned}$ & 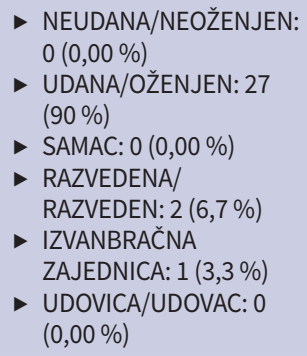 \\
\hline $\begin{array}{l}\text { OSOBE S } \\
\text { ANKSIOZNIM } \\
\text { POREMEĆAJEM }\end{array}$ & 30 & $\begin{array}{l}M-20(66,7 \%) \\
\check{Z}-10(33,3 \%)\end{array}$ & $20-66$ & 51 god. & $\begin{aligned} \text { OSNOVNA ŠKOLA: } 3 \\
\text { (10\%) } \\
\text { SREDNJA STRUČNA } \\
\text { SPREMA: } 21 \text { (70\%) } \\
\text { - VIŠA STRUČNA } \\
\text { SPREMA: } 3(10 \%) \\
\text { VISOKA STRUČNA } \\
\text { SPREMA: } 3(10 \%)\end{aligned}$ & $\begin{array}{l}\text { ZAPOSLEN/A: } 9(30 \%) \\
\text { NEZAPOSLEN/A: } 3 \\
\text { (10\%) } \\
\text { U MIROVINI: } 16(53 \%) \\
\text { - DRUGO: } 2(6,7 \%)\end{array}$ & $\begin{aligned} \text { - } & \text { NEUDANA/NEOŽENJEN: } \\
& 5(16,7 \%) \\
\text { - } & \text { UDANA/OŽENJEN: } 20 \\
& (66,7 \%) \\
\text { - } & \text { SAMAC: } 2(6,7 \%) \\
\text { - } & \text { RAZVEDENA/ } \\
& \text { RAZVEDEN: } 3(10 \%) \\
\text { - } & \text { IZVANBRAČNA } \\
& \text { ZAJEDNICA: } 0(0,00 \%) \\
\text { - } & \text { UDOVICA/UDOVAC: } 0 \\
& (0,00 \%)\end{aligned}$ \\
\hline $\begin{array}{l}\text { OSOBE S } \\
\text { PSIHOTIČNIM } \\
\text { POREMEĆAJEM }\end{array}$ & 30 & $\begin{array}{l}M-12(40 \%) \\
\grave{Z}-18(60 \%)\end{array}$ & $28-64$ & 42 god. & $\begin{aligned} \text { - OSNOVNA ŠKOLA: } 1 \\
\text { (3,3\%) } \\
\text { - SREDNJA STRUČNA } \\
\text { SPREMA: } 21(70 \%) \\
\text { - VIŠA STRUČNA } \\
\text { SPREMA: } 3(10 \%) \\
\text { - VISOKA STRUČNA } \\
\text { SPREMA: } 5(16,7 \%)\end{aligned}$ & $\begin{aligned} & \text { - } \text { ZAPOSLEN/A: } 4 \\
&(13,3 \%) \\
& \text { - } \text { NEZAPOSLEN/A: } 11 \\
&(36,7 \%) \\
& \text { - U MIROVINI: } 13 \\
& \\
& \text { (43,3\%) } \\
& \text { - DRUGO: } 2(6,7 \%)\end{aligned}$ & $\begin{aligned} & \text { NEUDANA/NEOŽENJEN: } \\
& 20(66,7 \%) \\
& \text { - } \text { UDANA/OŽENJEN: } 6 \\
&(6,7 \%) \\
& \text { - } \text { SAMAC: } 0(0,00 \%) \\
& \text { RAZVEDENA/ } \text { RAZV } \\
& \text { RAZVEDEN: } 2(6,7 \%) \\
& \text { - } \text { IZVANBRAČNA } \\
& \text { ZAJEDNICA: } 0(0,00 \%) \\
& \text { UDOVICA/UDOVAC: } 2 \\
& \\
&(6,7 \%)\end{aligned}$ \\
\hline $\begin{array}{l}\text { ZDRAVA } \\
\text { POPULACIJA }\end{array}$ & 30 & $\begin{array}{l}M-7(23,3 \%) \\
\check{Z}-23(76,7 \%)\end{array}$ & $27-57$ & 37 god. & $\begin{aligned} \text { - OSNOVNA ŠKOLA: } 0 \\
\text { (0,00 \%) } \\
\text { - SREDNJA STRUČNA } \\
\text { SPREMA: } 16(53,3 \%) \\
\text { - VIŠA STRUČNA } \\
\text { SPREMA: } 10(33,3 \%) \\
\text { - VISOKA STRUČNA } \\
\text { SPREMA: } 4(13,3 \%)\end{aligned}$ & $\begin{aligned} \text { - ZAPOSLEN/A: } 29 \\
\text { (96,7\%) } \\
\text { - NEZAPOSLEN/A: } \\
\text { O (0,00\%) } \\
\text { - U MIROVINI: } 0(0,00 \%) \\
\text { - DRUGO: } 1(3,3 \%)\end{aligned}$ & $\begin{aligned} & \text { - } \text { NEUDANA/NEOŽENJEN: } \\
& 10(33,3 \%) \\
& \text { - } \text { UDANA/OŽENJEN: } 18 \\
&(60,0 \%) \\
& \text { - } \text { SAMAC: } 0(0,00 \%) \\
& \text { - } \text { RAZVEDENA/ } \\
& \text { RAZVEDEN: } 2(6,7 \%) \\
& \text { - } \text { IZVANBRAČNA } \\
& \text { ZAJEDNICA: } 0(0,00 \%) \\
& \text { UDOVICA/UDOVAC: } 0 \\
& \\
& \text { (0,00\%) }\end{aligned}$ \\
\hline UKUPNO & 120 & $\begin{array}{l}M-52(43,3 \%) \\
\text { Ž- - } 8(56,7 \%)\end{array}$ & $20-66$ & 45 god. & $\begin{aligned} \text { OSNOVNA ŠKOLA: } 8 \\
\text { (6,7 \%) } \\
\text { SREDNJA STRUČNA } \\
\text { SPREMA: } 81 \text { ( } 67,5 \%) \\
\text { VIŠA STRUČNA } \\
\text { SPREMA: } 17(14,2 \%) \\
\text { VISOKA STRUČNA } \\
\text { SPREMA: } 14 \text { (11,7\%) }\end{aligned}$ & $\begin{aligned} & \text { ZAPOSLEN/A: } 61 \\
& (50,8 \%) \\
\text { - } & \text { NEZAPOSLEN/A: } \\
& 21(17,5 \%) \\
& \text { U MIROVINI: } 33 \\
& (27,5 \%) \\
\text { - } & \text { DRUGO: } 5(4,2 \%)\end{aligned}$ & $\begin{aligned} \text { - } & \text { NEUDANA/NEOŽENJEN: } \\
& 35(29,2 \%) \\
\text { - } & \text { UDANA/OŽENJEN: } 71 \\
& (59,2 \%) \\
\text { - } & \text { SAMAC: } 2(1,7 \%) \\
\text { - } & \text { RAZVEDENA/ } \\
& \text { RAZVEDEN: } 9(7,5 \%) \\
\text { - } & \text { IZVANBRAČNA } \\
& \text { ZAJEDNICA: } 1(0,8 \%) \\
\text { - } & \text { UDOVICA/UDOVAC: } 2 \\
& (1,7 \%)\end{aligned}$ \\
\hline
\end{tabular}


skale - skalu osamljivanja i skalu potiskivanja emocija. Upotrebljavao se dispozicijski oblik upitnika COPE. Odgovori su bodovani na skali Likertova tipa od pet stupnjeva (0 - 4), a glasili su „nikada se tako ne ponašam“, „katkad se tako ponašam“, „obično se tako ponašam“, "često se tako ponašam“ i „uvijek se tako ponašam“. Konačni rezultat svakog sudionika oblikuje se kao kompozit zbrajanja čestica koje tvore pojedinu skalu.

Upitnik COPE sastoji se od 17 skala koje čine sljedeće stilove sučeljavanja: 1. Pozitivna interpretacija i rast ličnosti odnosi se na viđenje dane situacije u povoljnom svjetlu ili korištenje dobrim stranama situacije. 2. Aktivno sučeljavanje odnosi se na poduzimanje akcije ili napora da bi se uklonio ili izbjegao stresor. 3. Planiranje se odnosi na razmišljanje o konfrontaciji sa stresom i suočavanje s naporima. 4. Prihvaćanje se odnosi na prihvaćanje činjenice da se stresni događaj dogodio $\mathrm{i}$ da je stvaran. 5. Obuzdavanje sučeljavanja odnosi se na pasivno sučeljavanje obuzdavanjem pokušaja sučeljavanja dok god to bude potrebno. 6. Potiskivanje kompeticijskih aktivnosti predstavlja usmjeravanje pažnje s drugih aktivnosti, kako bi se potpunije koncentriralo na sučeljavanje sa stresom. 7 . Negiranje se odnosi na pokušaje da se odbije realnost stresnog događaja. 8. Ponašajno izbjegavanje predstavlja odustajanje ili povlačenje napora u smjeru postizanja cilja s kojim interferira stresor. 9. Mentalno izbjegavanje odnosi se na psihološki dezangažman od cilja s kojim interferira stresor ma- štanjem, spavanjem i samodestruktivnim ponašanjem. 10. Traženje socijalne podrške zbog emocionalnih razloga odnosi se na primanje simpatije ili emocionalne podrške. 11. Traženje socijalne podrške zbog instrumentalnih razloga predstavlja traženje pomoći, informacija ili savjeta o tome što da radimo. 12. Ventiliranje emocija predstavlja povećanu svjesnost o stresnom događaju uz tendenciju da se emocije ventiliraju i izraze. 13. Humor se odnosi na korištenje šalama i humorom u vezi sa stresnim situacijama. 14. Alkohol predstavlja konzumaciju alkoholnih pića. 15. Religija predstavlja oslanjanje na vjeru u boga i religijska osjećanja. 16. Fizička izolacija odnosi se na tendenciju povlačenja od drugih ljudi i potrebu da se bude sam. 17. Potiskivanje emocija predstavlja neizražavanje emocija. Ove su skale podvrgnute faktorskoj analizi drugog reda u istraživanju Knežević (1993) 24 na uzorku od 403 sudionika u sklopu prve adaptacije skale u našim kulturalnim uvjetima. Dobivena su tri faktora koje su autori nazvali: problemu usmjereno sučeljavanje, emocijama usmjereno sučeljavanje i sučeljavanje izbjegavanjem. Pouzdanost tipa Cronbach alpha za pojedine skale kreće se u rasponu od 0,52 do 0,9 , a test-retest pouzdanosti u rasponu od 0,34 do $0,72^{24}$.

Pouzdanost upitnika COPE, procijenjena Cronbachovim alpha koeficijentom, na našem ukupnom uzorku iznosi 0,8041 , dok se za pojedine ljestvice kreće u rasponu od $-0,2$ do 0,64 .

\begin{tabular}{|c|c|c|c|}
\hline & Tablica 2. Dužina liječenja u mjesecima & PROSJEK \\
\hline SKUPINE SUDIONIKA & MINIMUM & MAKSIMUM & 6 godina (72 mjeseca) \\
\hline $\begin{array}{c}\text { OSOBE S DEPRESIVNIM } \\
\text { POREMEĆAJEM }\end{array}$ & 2 mjeseca & 480 mjeseci & 6 godina (72 mjeseca) \\
$\begin{array}{c}\text { OSOBE S ANKSIOZNIM } \\
\text { POREMEĆAJEM }\end{array}$ & 2 mjeseca & 288 mjeseci & 13 godina (136 mjeseci) \\
\hline $\begin{array}{c}\text { OSOBE S PSIHOTIČNIM } \\
\text { POREMEĆAJEM }\end{array}$ & 0 mjeseci & 384 mjeseca & \\
\hline
\end{tabular}

\begin{tabular}{|c|c|c|c|}
\hline \multicolumn{4}{|c|}{ Tablica 3. Broj hospitalizacija } \\
\hline SKUPINE SUDIONIKA & MINIMUM & MAKSIMUM & PROSJEK \\
\hline $\begin{array}{c}\text { OSOBE S DEPRESIVNIM } \\
\text { POREMEĆAJEM }\end{array}$ & 0 & 5 & 1 hospitalizacija \\
\hline $\begin{array}{c}\text { OSOBE S ANKSIOZNIM } \\
\text { POREMEĆAJEM }\end{array}$ & 0 & 15 & 3 hospitalizacija \\
\hline $\begin{array}{c}\text { OSOBE S PSIHOTIČNIM } \\
\text { POREMEĆAJEM }\end{array}$ & 0 & 50 & 7 hospitalizacija \\
\hline
\end{tabular}


Navedeni stilovi sučeljavanja uključuju različito grupirano sučeljavanje. Sučeljavanje usmjereno na problem uključuje: pozitivnu interpretaciju i rast ličnosti, aktivno sučeljavanje, planiranje, prihvaćanje, obuzdavanje sučeljavanja i potiskivanje kompetencijskih aktivnosti. Sučeljavanje usmjereno na emocije uključuje: traženje socijalne podrške zbog emocionalnih razloga i zbog instrumentalnih razloga te ventiliranje emocija. Stilovi izbjegavanja uključuju: negiranje, ponašajno i mentalno izbjegavanje, humor, religiju, alkohol, fizičku izolaciju i potiskivanje emocija.

\section{Rezultati}

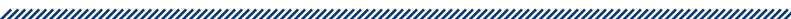

Primjenom upitnika COPE željelo se provjeriti postoji li razlika u stilovima sučeljavanja sa stresom između skupina kojima je dijagnosticirana psihička bolest te razlikuju li se navedene skupine u odnosu na komparabilnu skupinu koja predstavlja zdravu populaciju.
U tablicama 4, 5, 6 i 7 prikazani su rasponi, aritmetičke sredine i standardne devijacije za svaku pojedinu skupinu te sve stilove sučeljavanja i tri izdvojena faktora (stil sučeljavanja usmjeren na problem, stil sučeljavanja usmjeren na emocije te stil izbjegavanja). Kako bismo provjerili postoji li statistički značajna razlika između pojedinih stilova sučeljavanja u odnosu na različite skupine sudionika kojima je dijagnosticirana psihička bolest i skupinu koja predstavlja zdravu populaciju, provedena je analiza varijance. $\mathrm{U}$ tablici 8 prikazane su dobivene vrijednosti. Iz tablice 8 vidljivo je da je testiranje značajnosti razlika između skupina oboljelih od psihičke bolesti i zdravih u stilovima sučeljavanja pokazalo statistički značajne razlike u: pozitivnoj interpretaciji $(F=4,861 ; p=0,003)$, negiranju $(F=4,097 ; p=0,008)$, ponašajnom dezangažmanu $(F=11,391 ; p=0)$, alkoholu ( $F=8,567 ; p=0)$, fizičkoj izolaciji $(F=15,903 ; p=0)$ i potiskivanju emocija $(F=5,278 ; p=0,002)$. Kako bismo utvrdili smjer navedenih razlika, učinjena je dodatna analiza Scheffeovim post hoc testom. Scheffeov post hoc test pokazao je da se zdrava populacija statistički značajno češće koristila pozitivnom interpretacijom

\begin{tabular}{|c|c|c|c|c|c|}
\hline $\begin{array}{c}\text { Tablica 4. Prosječne vrijednosti, raspon i raspršenja rezultata } \\
\text { na skalama suočavanja za skupinu depresivnih }\end{array}$ \\
\hline Pozitivna interpretacija & M & SD & Min. & Maks. \\
\hline Aktivno suočavanje & 6,23 & 3,370 & 1 & 14 \\
\hline Planiranje & 7,57 & 3,360 & 2 & 15 \\
\hline Prihvaćanje & 10,03 & 3,970 & 3 & 18 \\
\hline Obuzdavanje suočavanja & 7,66 & 3,015 & 3 & 15 \\
\hline Potiskivanje kompeticijskih aktivnosti & 7,37 & 2,918 & 1 & 16 \\
\hline Negiranje & 5,10 & 2,369 & 1 & 12 \\
\hline Ponašajni dezangažman & 4,13 & 3,598 & 0 & 15 \\
\hline Mentalni dezangažman & 8,40 & 3,490 & 2 & 17 \\
\hline Socijalna podrška emocije & 10,63 & 5,027 & 2 & 22 \\
\hline Socijalna podrška instrumentalno & 6,03 & 3,489 & 2 & 15 \\
\hline Ventiliranje emocija & 7,57 & 3,963 & 2 & 19 \\
\hline Humor & 6,03 & 2,895 & 2 & 12 \\
\hline Alkohol & 2,80 & 3,428 & 0 & 12 \\
\hline Religija & 5,27 & 4,770 & 0 & 16 \\
\hline Fižčka izolacija & 6,90 & 5,202 & 0 & 16 \\
\hline Potiskivanje emocija & 10,07 & 3,581 & 4 & 16 \\
\hline Suočavanja usmjerena na problem & 7,57 & 3,441 & 2 & 15 \\
\hline Suočavanje usmjereno na emocije & 10,47 & 4,776 & 1 & 22 \\
\hline Strategije izbjegavanja & 4,97 & 1,921 & 1 & 8 \\
\hline
\end{tabular}


u odnosu na depresivne ( $M D=2,9 ; p=0,01)$. Također je vidljivo da se skupina oboljelih od psihoza u odnosu na depresivne sudionike statistički značajno češće $(M D=2,633 ; p=0,025)$ koristila pozitivnom interpretacijom kao stilom sučeljavanja. Negiranje se pokazalo kao statistički značajno češće primjenjivana strategija sučeljavanja kod sudionika iz skupine anksioznih $(M D=2,3$; $\mathrm{p}=0,041)$ i skupine psihoza (MD = 2,367; $\mathrm{p}=0,034) \mathrm{u}$ odnosu na zdravu populaciju. Sve tri skupine oboljelih od psihičkih poremećaja prema dobivenoj post hoc analizi statistički su se značajno češće koristile ponašajnim dezangažmanom kao stilom sučeljavanja u odnosu na zdravu populaciju (depresivni $M D=4,4 ; p=0$, anksiozni $M D=3,5 ; p=0$ i psihoze $M D=2,33 ; p=0$ ). Alkohol se pokazao kao statistički značajno češće primjenjivana strategija sučeljavanja kod oboljelih od depresije u odnosu na zdravu populaciju ( $M D=4,6 ; p=0)$ i psihoze $(M D=3,23 ; p=0,027)$. Skupina oboljelih od psihoza prema dobivenim rezultatima statistički se značajno češće $(M D=3,83 ; p=0,047)$ koristila religijom kao stilom sučeljavanja u odnosu na zdravu populaciju. Fizička izolacija pokazala se statistički značajno češćom strategijom sučeljavanja kod skupine anksioznih ( $M D=4,4 ; p=0)$ i psihoza (MD=3,867; $p=0,003)$ u odnosu na zdravu populaciju. Skupina oboljelih od depresivnog poremećaja statistički se značajno češće koristila fizičkom izolacijom kao stilom sučeljavanja u odnosu na pacijente s psihozama ( $M D=3,0 ; p=0,35$ ) i zdravu populaciju $(M D=6,867 ; p=0)$. Potiskivanje emocija kao strategija sučeljavanja pokazalo se statistički značajno češće primjenjivano kod depresivnih u odnosu na zdravu populaciju (MD = 3,2; $\mathrm{p}=0,005)$.

Preuzeta je i podjela na stilove sučeljavanja kakva je dobivena u istraživanju Hudek-Knežević i Kardum (1993) ${ }^{24}$. Razlikujemo stilove sučeljavanja usmjerene na problem (pozitivna interpretacija i rast ličnosti, aktivno sučeljavanje, planiranje, prihvaćanje, obuzdavanje sučeljavanja i potiskivanje kompeticijskih aktivnosti), stilove sučeljavanja usmjerene na emocije (traženje socijalne podrške zbog emocionalnih razloga i zbog instrumentalnih razloga te ventiliranje emocija) i stilove izbjegavanja (negiranje, ponašajno i mentalno izbjegavanje, humor, religija, alkohol, fizička izolacija i potiskivanje

\begin{tabular}{|c|c|c|c|c|}
$\begin{array}{c}\text { Tablica 5. Prosječne vrijednosti, raspon i raspršenja rezultata na skalama suočavanja } \\
\text { za skupinu anksioznih }\end{array}$ \\
\begin{tabular}{|c|c|c|c|c|}
\hline \\
\hline Pozitivna interpretacija
\end{tabular} & M & SD & Min. & Maks. \\
\hline Aktivno suočavanje & 7,77 & 2,897 & 3 & 15 \\
\hline Planiranje & 8,93 & 3,685 & 4 & 16 \\
\hline Prihvaćanje & 11,67 & 4,574 & 5 & 20 \\
\hline Obuzdavanje suočavanja & 8,73 & 3,183 & 4 & 15 \\
\hline Potiskivanje kompeticijskih aktivnosti & 7,43 & 3,048 & 3 & 16 \\
\hline Negiranje & 5,60 & 2,372 & 2 & 12 \\
\hline Ponašajni dezangažman & 4,37 & 2,988 & 0 & 13 \\
\hline Mentalni dezangažman & 7,50 & 3,511 & 1 & 14 \\
\hline Socijalna podrška emocije & 12,37 & 5,468 & 2 & 26 \\
\hline Socijalna podrška instrumentalno & 6,67 & 4,663 & 0 & 16 \\
\hline Ventiliranje emocija & 7,77 & 4,869 & 0 & 17 \\
\hline Humor & 6,87 & 3,137 & 2 & 12 \\
\hline Alkohol & 3,20 & 2,683 & 0 & 11 \\
\hline Religija & 4,63 & 5,308 & 0 & 16 \\
\hline Fizička izolacija & 6,27 & 5,626 & 0 & 16 \\
\hline Potiskivanje emocija & 7,60 & 4,477 & 0 & 16 \\
\hline Suočavanja usmjerena na problem & 6,70 & 3,861 & 0 & 14 \\
\hline Suočavanje usmjereno na emocije & 11,77 & 3,674 & 3 & 18 \\
\hline Strategije izbjegavanja & 5,20 & 2,295 & 1 & 10 \\
\hline
\end{tabular}


emocija). Iz tablice 8 vidljivo je da analiza varijance ne ukazuje na statistički značajne razlike u odnosu na pojedine stilove sučeljavanja, tj. da između stilova sučeljavanja na problem, stilova sučeljavanja na emocije te stilova izbjegavanja nema razlike između pojedinih skupina. Daljnjom analizom željelo se provjeriti postoje li razlike u odnosu na spol, dob, bračni status, zanimanje i zaposlenje kada govorimo o stilu sučeljavanja kod oboljelih od depresije, psihoza i anksioznih poremećaja.

U skupni oboljelih od anksioznih poremećaja pokazala se statistički značajna razlika između zaposlenih i nezaposlenih u korištenju religijom kao stilom sučeljavanja $(F=7,962 ; p=0,009)$. Pri tome su zaposleni skloniji religiji kao stilu sučeljavanja ( $M=7,21 ; \mathrm{SD}=6,051)$ u odnosu na nezaposlene ( $M=6,36 ; S D=3,472)$. $U$ skupini oboljelih od psihoza pokazalo se da postoji statistički značajna razlika između oženjenih i grupe neoženjenih i samaca u korištenju alkoholom kao stilom sučeljavanja $(F=7,815 ; p=0,009)$. Oženjeni su se pokazali skloniji alkoholu kao strategiji sučeljavanja $(M=4,5 ; S D=6,124) u$ odnosu na neoženjene i razvedene $(M=1,42 ; S D=2,22)$.
$\mathrm{U}$ istoj se skupini pokazalo da su neoženjeni i razvedeni statistički značajno skloniji religiji kao stilu sučeljavanja $(F=8,988 ; p=0,006)$. U skupini oboljelih od depresije uočila se statistički značajna razlika između muškaraca i žena kada govorimo o potiskivanju kao strategiji sučeljavanja ( $F=11,237, p=0,002)$. Žene u ovoj skupini statistički su se značajno češće koristile potiskivanjem emocija kao stilom sučeljavanja ( $M=7,88 ; S D=4,26) \mathrm{u}$ odnosu na muškarce ( $M=7,15 ; S D=2,03)$. $U$ istoj se skupini uočavala i statistički značajna razlika između sudionika sa završenom osnovnom školom i onih sa završenom srednjom školom kod mentalnog dezangažmana kao stila sučeljavanja $(F=10,66 ; p=0,003)$. Sudionici sa završenom srednjom školom statistički su se značajno češće koristili mentalnim dezangažmanom kao stilom sučeljavanja ( $M=10,78 ; S D=3,84)$. Potrebno je naglasiti da su sve navedene razlike vjerojatno jednim dijelom $i$ odraz neravnomjernog omjera u kojem je unutar svake kategorije zastupljen spol, zanimanje itd. Statističkom obradom pokušalo se provjeriti postoje li razlike u načinu sučeljavanja u odnosu na dužinu liječenja i broj hospitalizacija kod pojedine skupine oboljelih, no nisu

\begin{tabular}{|c|c|c|c|c|}
\hline & M & SD & Min. & Maks. \\
\hline Pozitivna interpretacija & 8,87 & 3,812 & 2 & 16 \\
\hline Aktivno suočavanje & 9,30 & 3,932 & 1 & 16 \\
\hline Planiranje & 12,00 & 4,871 & 1 & 20 \\
\hline Prihvaćanje & 9,20 & 3,448 & 3 & 16 \\
\hline Obuzdavanje suočavanja & 7,70 & 3,725 & 1 & 16 \\
\hline Potiskivanje kompeticijskih aktivnosti & 6,10 & 2,917 & 0 & 12 \\
\hline Negiranje & 4,43 & 3,350 & 0 & 15 \\
\hline Ponašajni dezangažman & 6,33 & 2,975 & 1 & 12 \\
\hline Mentalni dezangažman & 12,07 & 5,452 & 3 & 25 \\
\hline Socijalna podrška emocije & 8,67 & 4,922 & 0 & 16 \\
\hline Socijalna podrška instrumentalno & 8,97 & 5,068 & 0 & 20 \\
\hline Ventiliranje emocija & 5,63 & 3,429 & 0 & 12 \\
\hline Humor & 3,80 & 2,905 & 0 & 12 \\
\hline Alkohol & 2,03 & 3,459 & 0 & 16 \\
\hline Religija & 8,57 & 5,722 & 0 & 16 \\
\hline Fizička izolacija & 7,07 & 4,556 & 0 & 16 \\
\hline Potiskivanje emocija & 5,37 & 3,200 & 0 & 14 \\
\hline Suočavanja usmjerena na problem & 12,27 & 4,386 & 3 & 22 \\
\hline Suočavanje usmjereno na emocije & 4,73 & 2,303 & 0 & 8 \\
\hline Strategije izbjegavanja & 15,53 & 5,551 & 2 & 25 \\
\hline
\end{tabular}


uočene statistički značajne razlike. Iz početne je analize deskriptivne statistike za cijeli uzorak vidljivo da je u skupini osoba s psihotičnim poremećajem znatno veći broj hospitalizacija i duži sam tijek liječenja, no značajne razlike u stilovima sučeljavanja u odnosu na dužinu i tijek liječenja nisu zamijećene.

\section{Rasprava}

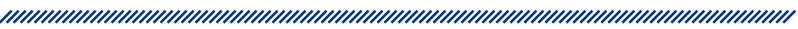

U ovom nas je istraživanju zanimalo utječe li psihička bolest na stilove sučeljavanja sa stresom i na koji način. Stoga smo istraživali postoji li razlika u sučeljavanju oboljelih od depresije, psihotičnih poremećaja i anksioznih poremećaja u odnosu na zdravu populaciju. Rezultati istraživanja govore u prilog postojanja razlike u izboru stilova sučeljavanja kod oboljelih od psihičkih bolesti u odnosu na zdravu populaciju. $U$ našem su se istraživanju oboljeli od psihičkih poremećaja češće koristili slabije adaptiranim stilovima sučeljavanja povezanima s izbjegavanjem, što je u skladu s istraživanjima povezanosti slabije prilagođenih stilova sučeljavanja s psihičkom bolešću. U uzorku zdrave populacije pronađena je statistički značajna razlika u korištenju pozitivnom interpretacijom, koja pripada prilagođenijim stilovima sučeljavanja, što je u skladu s istraživanjima koja govore u prilog povezanosti funkcionalnijih stilova sučeljavanja sa stresom s mentalnim zdravljem. Rezultat da se oboljeli od psihoze također koriste pozitivnom interpretacijom na prvi pogled predstavlja kontradiktoran podatak s obzirom na to da očekujemo korištenje manje adaptabilnim sučeljavanjem, čemu govori u prilog da su stilovi sučeljavanja više povezani s ličnošću nego s bolešću. Korištenje ovim stilom u našem uzorku kod oboljelih od psihoze možemo pripisati i mogućnosti utjecaja psihosocijalnih programa i psihoterapije u kojima su sudjelovali tijekom liječenja, njihovim karakteristikama ličnosti, premorbidno boljem socijalnom funkcioniranju i nekim drugim faktorima. Istraživanje rađeno na kliničkom uzorku pacijenata u Dnevnoj bolnici i u Odjelu za rehabilitaciju pokazuje vi-

\begin{tabular}{|c|c|c|c|c|}
$\begin{array}{c}\text { Tablica 7. Prosječne vrijednosti, raspon i raspršenja rezultata na skalama suočavanja } \\
\text { za skupinu zdrave populacije }\end{array}$ \\
\hline Pozitivna interpretacija & M & SD & Min. & Maks. \\
\hline Aktivno suočavanje & 9,13 & 2,933 & 4 & 15 \\
\hline Planiranje & 8,70 & 2,938 & 1 & 14 \\
\hline Prihvaćanje & 12,37 & 4,311 & 1 & 20 \\
\hline Obuzdavanje suočavanja & 7,57 & 2,459 & 2 & 12 \\
\hline Potiskivanje kompeticijskih aktivnosti & 6,87 & 2,726 & 0 & 13 \\
\hline Negiranje & 5,10 & 2,310 & 0 & 9 \\
\hline Ponašajni dezangažman & 2,07 & 2,067 & 0 & 8 \\
\hline Mentalni dezangažman & 4,00 & 2,197 & 0 & 8 \\
\hline Socijalna podrška emocije & 9,53 & 4,377 & 3 & 22 \\
\hline Socijalna podrška instrumentalno & 8,67 & 4,245 & 1 & 16 \\
\hline Ventiliranje emocija & 8,50 & 3,963 & 1 & 16 \\
\hline Humor & 5,93 & 2,753 & 1 & 11 \\
\hline Alkohol & 4,60 & 2,444 & 1 & 11 \\
\hline Religija & 0,67 & 1,709 & 0 & 7 \\
\hline Fizička izolacija & 4,73 & 4,008 & 0 & 16 \\
\hline Potiskivanje emocija & 3,20 & 2,696 & 0 & 11 \\
\hline Suočavanja usmjerena na problem & 4,37 & 2,930 & 0 & 10 \\
\hline Suočavanje usmjereno na emocije & 10,57 & 3,549 & 4 & 20 \\
\hline Strategije izbjegavanja & 4,57 & 1,736 & 1 & 8 \\
\hline
\end{tabular}




\section{Tablica 8. Prikaz rezultata analize varijance}

\begin{tabular}{|c|c|c|c|c|c|c|}
\hline & & $\begin{array}{c}\text { Suma } \\
\text { kvadrata }\end{array}$ & df & $\begin{array}{l}\text { Sredina } \\
\text { kvadrata }\end{array}$ & $\mathrm{F}$ & Sig. \\
\hline \multirow{3}{*}{ Pozitivna interpretacija } & Među grupama & 156,333 & 3 & 52,111 & 4,861 & 0,003 \\
\hline & Unutar grupe & 1243,667 & 116 & 10,721 & & \\
\hline & Ukupno & 1400,000 & 119 & & & \\
\hline \multirow{3}{*}{ Aktivno suočavanje } & Među grupama & 50,292 & 3 & 16,764 & 1,370 & 0,256 \\
\hline & Unutar grupe & 1419,833 & 116 & 12,240 & & \\
\hline & Ukupno & 1470,125 & 119 & & & \\
\hline \multirow{3}{*}{ Planiranje } & Među grupama & 95,367 & 3 & 31,789 & 1,610 & 0,191 \\
\hline & Unutar grupe & 2290,600 & 116 & 19,747 & & \\
\hline & Ukupno & 2385,967 & 119 & & & \\
\hline \multirow{3}{*}{ Prihvaćanje } & Među grupama & 58,121 & 3 & 19,374 & 2,085 & 0,106 \\
\hline & Unutar grupe & 1068,585 & 115 & 9,292 & & \\
\hline & Ukupno & 1126,706 & 118 & & & \\
\hline \multirow{3}{*}{ Obuzdavanje suočavanja } & Među grupama & 10,892 & 3 & 3,631 & 0,371 & 0,774 \\
\hline & Unutar grupe & 1134,100 & 116 & 9,777 & & \\
\hline & Ukupno & 1144,992 & 119 & & & \\
\hline \multirow{3}{*}{ Potiskivanje kompeticijskih aktivnosti } & Među grupama & 20,625 & 3 & 6,875 & 1,097 & 0,354 \\
\hline & Unutar grupe & 727,300 & 116 & 6,270 & & \\
\hline & Ukupno & 747,925 & 119 & & & \\
\hline \multirow{3}{*}{ Negiranje } & Među grupama & 114,833 & 3 & 38,278 & 4,097 & 0,008 \\
\hline & Unutar grupe & 1083,667 & 116 & 9,342 & & \\
\hline & Ukupno & 1198,500 & 119 & & & \\
\hline \multirow{3}{*}{ Ponašajni dezangažman } & Među grupama & 326,225 & 3 & 108,742 & 11,391 & 0,000 \\
\hline & Unutar grupe & 1107,367 & 116 & 9,546 & & \\
\hline & Ukupno & 1433,592 & 119 & & & \\
\hline \multirow{3}{*}{ Mentalni dezangažman } & Među grupama & 156,033 & 3 & 52,011 & 2,000 & 0,118 \\
\hline & Unutar grupe & 3017,267 & 116 & 26,011 & & \\
\hline & Ukupno & 3173,300 & 119 & & & \\
\hline \multirow{3}{*}{ Socijalna podrška emocije } & Među grupama & 167,025 & 3 & 55,675 & 2,924 & 0,037 \\
\hline & Unutar grupe & 2208,967 & 116 & 19,043 & & \\
\hline & Ukupno & 2375,992 & 119 & & & \\
\hline \multirow{3}{*}{ Socijalna podrška instrumentalno } & Među grupama & 38,000 & 3 & 12,667 & 0,627 & 0,599 \\
\hline & Unutar grupe & 2343,200 & 116 & 20,200 & & \\
\hline & Ukupno & 2381,200 & 119 & & & \\
\hline \multirow{3}{*}{ Ventiliranje emocija } & Među grupama & 25,100 & 3 & 8,367 & 0,891 & 0,448 \\
\hline & Unutar grupe & 1089,267 & 116 & 9,390 & & \\
\hline & Ukupno & 1114,367 & 119 & & & \\
\hline \multirow{3}{*}{ Humor } & Među grupama & 55,200 & 3 & 18,400 & 2,206 & 0,091 \\
\hline & Unutar grupe & 967,600 & 116 & 8,341 & & \\
\hline & Ukupno & 1022,800 & 119 & & & \\
\hline \multirow{3}{*}{ Alkohol } & Među grupama & 422,833 & 3 & 140,944 & 8,567 & 0,000 \\
\hline & Unutar grupe & 1908,467 & 116 & 16,452 & & \\
\hline & Ukupno & 2331,300 & 119 & & & \\
\hline
\end{tabular}




\begin{tabular}{|c|c|c|c|c|c|c|}
\hline & & $\begin{array}{c}\text { Suma } \\
\text { kvadrata }\end{array}$ & df & $\begin{array}{c}\text { Sredina } \\
\text { kvadrata }\end{array}$ & $\mathrm{F}$ & Sig. \\
\hline \multirow{3}{*}{ Religija } & Među grupama & 226,567 & 3 & 75,522 & 2,810 & 0,043 \\
\hline & Unutar grupe & 3117,800 & 116 & 26,878 & & \\
\hline & Ukupno & 3344,367 & 119 & & & \\
\hline \multirow{3}{*}{ Fizička izolacija } & Među grupama & 726,233 & 3 & 242,078 & 15,903 & 0,000 \\
\hline & Unutar grupe & 1765,733 & 116 & 15,222 & & \\
\hline & Ukupno & 2491,967 & 119 & & & \\
\hline \multirow{3}{*}{ Potiskivanje emocija } & Među grupama & 180,400 & 3 & 60,133 & 5,278 & 0,002 \\
\hline & Unutar grupe & 1321,600 & 116 & 11,393 & & \\
\hline & Ukupno & 1502,000 & 119 & & & \\
\hline \multirow{3}{*}{ Suočavanja usmjerena na problem } & Među grupama & 71,400 & 3 & 23,800 & 1,397 & 0,247 \\
\hline & Unutar grupe & 1976,067 & 116 & 17,035 & & \\
\hline & Ukupno & 2047,467 & 119 & & & \\
\hline \multirow{3}{*}{ Suočavanje usmjereno na emocije } & Među grupama & 6,867 & 3 & 2,289 & 0,530 & 0,663 \\
\hline & Unutar grupe & 501,000 & 116 & 4,319 & & \\
\hline & Ukupno & 507,867 & 119 & & & \\
\hline \multirow{3}{*}{ Strategije izbjegavanja } & Među grupama & 52,025 & 3 & 17,342 & 0,701 & 0,553 \\
\hline & Unutar grupe & 2869,900 & 116 & 24,741 & & \\
\hline & Ukupno & 2921,925 & 119 & & & \\
\hline
\end{tabular}

šu razinu funkcioniranja. Stoga su naši rezultati u skladu s istraživanjem Vrdoljaka o socijalnom funkcioniranju osoba s dijagnozom shizofrenije u odnosu na načine sučeljavanja sa stresom ${ }^{18}$. Njegovi rezultati pokazuju da se osobe koje imaju manja oštećenja socijalnog funkcioniranja koriste povoljnijim načinima sučeljavanja u stresnoj situaciji.

Statistički značajno korištenje negiranjem kao stilom sučeljavanja kod anksioznih i oboljelih od psihoze očekivani je rezultat, jer se negiranje ubraja u slabije prilagođene stilove sučeljavanja, čiju povećanu učestalost očekujemo kod oboljelih od psihičkih poremećaja. Također je očekivani rezultat da će se oboljeli od psihičkih poremećaja češće koristiti ponašajnim dezangažmanom u odnosu na zdravu populaciju s obzirom na to da je korištenje izbjegavajućim ponašanjem kao stilom nošenja sa stresom češće kod oboljelih od psihičkih poremećaja, što je u skladu s istraživanjima drugih stručnjaka²5, 23, 12. Međutim, kada se analiziraju stilovi sučeljavanja koji uključuju više stilova svrstanih u stilove sučeljavanja povezane s problemom, povezane s emocijama i izbjegavanjem, nema statistički značajne razlike u odnosu na zdravu populaciju i oboljele od psihičkih poremećaja. Ovaj podatak iznenađuje, s obzirom na to da smo očekivali da će u skladu s drugim istraživanjima biti razlike $u$ odnosu na emocionalni stil sučeljavanja koji smo očekivali naći kod oboljelih od depresije $^{6,7,8}$. Također smo očekivali češće korištenje stilovima izbjegavanja i manje korištenje sučeljavanjem okrenutim prema rješavanju problema ${ }^{12,13}$. Neusklađenost naših rezultata $s$ drugim istraživanjima možemo objasniti malim uzorkom, utjecajem psihoterapijskog procesa kojem su bili izloženi, osobnim karakteristikama ličnosti i mogućnošću utjecaja nekih drugih faktora koji mogu djelovati na sučeljavanje. Ponovno napominjemo da su u istraživanju sudjelovali pacijenti koji su prošli liječenje u Dnevnoj bolnici u kojoj se primjenjuju psihosocijalne metode liječenja ili je njihovo liječenje bilo u tijeku. Istraživanje je potvrdilo značaj različitih faktora na stilove sučeljavanja, kao što su bračni status, zaposlenost i spol.

U skupini osoba s psihozama pokazalo se da su se oženjeni češće koristili alkoholom kao stilom sučeljavanja (što pripada stilu izbjegavanja) od neoženjenih i razvedenih koji se više koriste religijom. U skupni oboljelih od anksioznih poremećaja pokazala se statistički značajna razlika između zaposlenih i nezaposlenih u korištenju religijom kao stilom sučeljavanja, pri čemu su zaposleni 
skloniji religiji u odnosu na nezaposlene. Razlika u sučeljavanju u odnosu na spol pronađena je jedino u uzorku oboljelih od depresije. U skupini oboljelih od depresije uočila se statistički značajna razlika između muškaraca i žena kada govorimo o potiskivanju kao stilu sučeljavanja. Žene u ovoj skupini statistički su se značajno češće koristile potiskivanjem emocija kao stilom sučeljavanja u odnosu na muškarce. Ovi su podatci u skladu s podatcima iz literature, međutim različiti su od podataka iz literature gdje se žene više koriste emocionalno fokusiranim sučeljavanjem ${ }^{8}$. U ovom su se uzorku žene koristile emocionalnim potiskivanjem, što ponovno govori u prilog složenosti i multidimenzionalnosti stila sučeljavanja na koji djeluju brojni faktori.

Potrebno je naglasiti da su sve ranije navedene razlike, kao i ova, vjerojatno jednim dijelom i odraz neravnomjernog omjera u kojem je unutar svake kategorije zastupljen spol, zaposlenost, obrazovni status itd. Očekivali smo da će se oboljeli koji su bili češće hospitalizirani koristiti slabije prilagođenim načinima sučeljavanja. Istraživanje nije potvrdilo utjecaj broja hospitalizacija i dužine liječenja na stilove sučeljavanja. U ovom su uzorku najveći broj hospitalizacija imali oboljeli od psihotičnih poremećaja, ali to nije utjecalo na specifičnosti sučeljavanja. Ovaj rezultat govori u prilog tome da su stilovi sučeljavanja više povezani s ličnošću nego $\mathrm{s}$ bolešću.

Rezultati istraživanja o stilovima sučeljavanja između oboljelih od psihičkih poremećaja i zdrave populacije potvrđuju da postoji razlika u sučeljavanju u smislu češćeg korištenja funkcionalnijim mehanizmima sučeljavanja u odnosu na oboljele od psihičkih poremećaja. $S$ druge strane, nismo pronašli specifične načine sučeljavanja u odnosu na pojedine dijagnostičke skupine, što govori u prilog podatcima iz literature da sučeljavanje ovisi o brojnim faktorima, od kojih je dimenzija ličnosti vrlo značajna. Ovo ne umanjuje značaj stilova sučeljavanja u nastanku ishoda mentalnog poremećaja, već upućuje na potrebu individualne procjene utjecaja stresa te prepoznavanje stilova sučeljavanja i rada na korištenju efikasnijim stilovima sučeljavanja, što bi moglo utjecati na povoljniji ishod liječenja i prevenciju ponovnog pogoršanja bolesti. Stoga je potrebno procjenjivati stilove sučeljavanja u svakom pojedinačnom slučaju bez obzira na dijagnozu, kako bi se intervencijom u tom području pomoglo pacijentima da postignu bolje rezultate liječenja. Rezultate ovog istraživanja, naravno, treba uzeti s oprezom zbog malog uzorka i neravnomjernosti uzorka s obzirom na spol, zaposlenje i druge faktore.

\section{Zaključak}

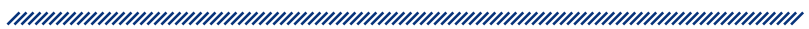

Ovim smo istraživanjem testiranjem značajnosti razlika u stilovima sučeljavanja sa stresom između skupina oboljelih od psihičke bolesti i zdravih pokazali razlike u: pozitivnoj interpretaciji, negiranju, ponašajnom dezangažmanu, alkoholu, fizičkoj izolaciji i potiskivanju emocija. Pozitivnom su se interpretacijom češće koristile zdrava populacija i skupina oboljelih od psihotičnog poremećaja u odnosu na osobe s depresivnim poremećajem, a negiranje je kao strategija sučeljavanja prevladavala kod sudionika iz skupine s anksioznim poremećajem i skupine s psihotičnim poremećajem u odnosu na zdravu populaciju. Ponašajni dezangažman pokazao se kao strategija sučeljavanja u sve tri skupine oboljelih od psihičkih poremećaja, ali između pojedinih skupina nije bilo razlike između stilova sučeljavanja povezanih s problemom, stilova sučeljavanja povezanih s emocijama te stilova izbjegavanja. U skupini oboljelih od psihotičnog poremećaja pokazalo se da postoji statistički značajna razlika između oženjenih i grupe neoženjenih i samaca u korištenju alkoholom kao stilom sučeljavanja. Oženjeni su se pokazali skloniji alkoholu u odnosu na neoženjene i razvedene. $U$ istoj se skupini pokazala razlika i u religioznosti. Neoženjeni i razvedeni bili su skloniji religiji, dok je u skupni oboljelih od anksioznih poremećaja bilo razlike između zaposlenih i nezaposlenih u korištenju religijom kao stilom sučeljavanja. Zaposleni su bili skloniji religiji kao stilu sučeljavanja u odnosu na nezaposlene. Postoji statistički značajna razlika između muškaraca i žena u grupi sudionika s depresivnim poremećajem kada govorimo o potiskivanju kao stilu sučeljavanja. Žene u ovoj skupini češće se koriste potiskivanjem emocija kao stilom sučeljavanja u odnosu na muškarce. Pokazala se razlika u stupnju obrazovanja i korištenja mentalnim dezangažmanom, kojim su se češće koristili sudionici sa završenom srednjom školom. 


\section{Literatura}

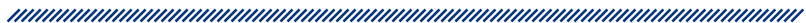

1. Havelka M. Zdravstvena psihologija. Jastrebarsko: Naklada Slap, 1998.

2. Lazarus RS, Folkman S. Stress, appraisal, and coping. New York: Springer, 1984.

3. Endler NS, Parker JDA. Multdimensional assessment of coping: A critical evaluation. Journal of Personality and Social Psychology. 1990;58:844-854.

4. Carver CS, Scheier MF, Weintraub JK. Assessing coping strategies: a theoretically based approach. Journal of Personality and Social Psychology. 1989;59:73-81.

5. Alloy LB, Clements CM. Illusion of control: inbulnerability to negative affect and depressive symptoms after laboratory amd natural stressors. Journal of Abnormal Psychology. 1992;101:234-245.

6. Ravindran AV, Anisman H, Merali Z, Charbonneau Y, Teiner J, Bialik RJ, Weins A, Ellis J, Griffiths J. Treatment of primary dysthymia with cognitive therapy and pharmacotherapy: clinical symptoms and functional impairments. American Journal of Psychiatry. 1999;156:1608-1617.

7. Ravindran AV, Matheson K, Griffiths J, Merali Z, Anisman $H$. Stress, coping, uplifts, and quality of life in subtypes of depression: a conceptual model and emerging data. Journal of Affective Disorders. 2002;71:121-130.

8. Leandro PG, Castillo D. Coping with stress and its relationship with personality dimensiones anxiety, and depression. Procedia - Social and Behavioral Sciences. 2010;5:1562-1573.

9. Nolen-Hoekaema S. Ruminative coping with depression. In: Heckhaisen J, Dweck CS. Motivation and Self Regulation Across the Life Span. Cambridge: Cambridge university press 1998; 237-256.

10. Endler NS, Parker JDA. Assessment of multidimensional coping: task, emotion and avoidance strategies. Psychological Assessment. 1994;6:50-60.

11. Holohan CJ, Moos RH, Holohan CK, Cronkite RC. Resource loss, resource gain and depressive symptoms: a 10 year model. Journal of Personality and Social Psychology. 1999; 77:620-629.

12. Billings AG, Cronkite RC, Moos RH. Social-environmental factors in unipolar depression: Comparisons of depressed patiens and nondepressed controls. Journal of Abnormal Psychology. 1983;92:119-133.

13. Coyne JC, Aldwin C, Lazarus RS. Depression and coping in stressful episodes. Journal of Abnormal Psychology. 1981;90:439-447.

14. Rios Martinez BP, Chavez Leon E, Rangel Rodrigez GA, Pedraza Moctezuma LG. Defense mechanisms in cardiovascular disease patients. Salud Mental. 2010;33:219-227.

15. Gispen-de Wied CC. Stress in shizophrenia: an integrative view. European Journal of Pharmacology. 2000;405(13):375-84.
16. Van den Bosch RJ, Rombouts RP. Coping and cognition in Schizophrenia and Depression. Comprenhensive Psychiatry. 1993;34(2):130-136.

17. Ritsner M, Kurs R, Gibel A, Hirschmann S, Shinkarenko E, Ratner Y. Predictors of quality of life in major paychoses: a naturalistic follow-up study. Journal of Clinical Psychiatry. 2003;64(3):308-15.

18. Vrdoljak M. Socijalno funkcioniranje osoba s dijagnozom shizofrenija u odnosu na načine sučeljavanja sa stresom. Magistarski rad. Zagreb: Medicinski fakultet Sveučilišta u Zagrebu; 2005.

19. Zubin J, Spring B. Vulnerability - a new view of shizophrenia. Journal of Abnormal Psychology. 1977;86(2):103-126.

20. Zubin J, Steinhauer SR, Condray R. Vulnerability to relapse in schizophrenia. The British Journal of Psychiatry Supplement. 1992; (18):13-8.

21. Nuechterlein KH, Dawson ME. A heuristic vulnerability/ stress model of schizophrenic episodes. Schizophrenia Bulletin. 1984;10:300-312.

22. Ivezić S. Rehabilitacija u psihijatriji: psihobiosocijalni pristup. Zagreb: Hrvatski liječnički zbor; 2010.

23. Carver CS, Scheier MF, Weintraub JK. Assessing coping strategies: a theoretically based approach. Journal of Personality and Social Psychology. 1989;59:73-81.

24. Hudek-Knežević J, Kardum I. Upitnik dispozicijskog i situacijskog sučeljavanja sa stresom i njihove psihometrijske značajke. Godišnjak Zavoda za psihologiju. 1993;43-60.

25. Van den Bosch RJ, Rombouts RP. Coping and cognition in schizophrenia and depression. Comprehensive Psychiatry. 1997;38(6):341-4. 


\section{STRESS COPING STYLES IN RELATION TO VARIOUS PSYCHIATRIC DISORDERS}

1 Zlata Pjević

1 Slađana Štrkalj Ivezić

2 Anja Melada

1 University Psychiatric Hospital Vrapče, Zagreb, Croatia

2 Department of Psychiatry, University Hospital Dubrava, Zagreb, Croatia

\section{Abstract}

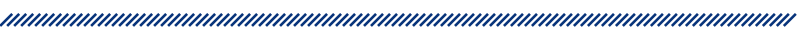

Introduction: Stress is one of the most common triggers of processes that lead to psychiatric disorders. Our objective was to determine whether there are differences in coping styles among participants with psychiatric disorders compared to a healthy population and differences in coping styles between the participants with psychiatric disorders due to demographic characteristics. Methods: Participants: The study included 120 participants divided into 4 groups of 30 participants. The participants diagnosed with a psychiatric disorder were divided into three groups: participants with a depressive disorder, anxiety disorders and psychotic disorders, and by gender, level of education, age, employment, marital status, length of treatment and number of hospitalizations. The fourth group consisted of healthy participants. Instruments: The adapted version of the dispositional form of the COPE questionnaire (Coping Orientation to Problems Experienced) was used. Results: Between the groups of participants with mental disorders and the healthy participants, coping styles showed statistically significant differences in positive interpretation, denial, behavioral disengagement, alcohol use, physical isolation and the suppression of emotions as well differences in terms of gender, age, marital status, occupation and employment. Discussion: Differences in coping styles in patients with psychiatric disorders are not specific to their psychopathology which is consistent with studies of other researchers. Participants in our study had finished or were in treatment as outpatients where psychosocial treatments are used, which could have affected their coping styles. Conclusion: The results of the study confirm that healthy people compared to people with psychiatric disorders use functional coping styles. We did not find specific coping styles in relation to a particular diagnostic group, which supports the data that coping depends on a number of factors.

Keywords : stress, coping with stress, coping styles, psychobiosocial model, psychosocial interventions 



\section{UPUTE ZA AUTORE}

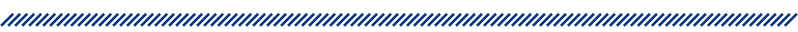

\section{AUTHOR GUIDELINES}

\section{Introduction}

Journal of Applied Health Sciences publishes original research, theoretical, methodological, review and professional papers from all areas of health sciences. The original research scientific and professional papers include reports on the research results based on data collected in quantitative and qualitative methodological procedures. Theoretical papers imply a comprehensive elaboration of possible explanations of specific phenomenon based on current understanding and theories complemented by new ideas and hypotheses. Methodological papers should give a comprehensive overview of methods, techniques and procedures of collecting and analyzing data that are innovative, not sufficiently known, or have thus far not been or have been rarely used in a particular field of health sciences. Review papers will have to relate to knowledge in the field of health science which has so far not been systematically shown, and which will have to be based on an appropriate set of relevant original research papers, i.e. those which are based on the results of meta-analyses with the representative corpus of original works.

\section{Paper structure}

Original research papers should use the general scientific paper format, in the sense that they are subdivided into several sections: Introduction which states the topic of the paper; Methods which specifies the methods used, materials and groups of patients and which enables the replication of research; clearly stated research Results and Discussion of the research and results with its Conclusions. Authors can get information on the format of original research papers, from the provided links, as well as in a series of books and articles published on the topic 
veznica, kao i u nizu knjiga i radova objavljenih na temu kvalitetnog pisanja znanstvenih i istraživačkih radova. Ostale vrste radova (teorijski, metodološki, pregledni) trebaju imati adekvatnu strukturu iz koje se jasno vidi osnovna ideja i slijed zaključaka, a uredništvo ostavlja pravo na sugestije i korekcije navedene strukture. Veličina teksta bi se trebala kretati u rasponu od 5 kartica do 20 kartica teksta pisanog jednostrukim proredom (jedna kartica teksta je 1800 znakova sa jednostrukim proredom). Svi radovi trebaju imati sažetak, veličine do 250 riječi, koji prati strukturu osnovnog teksta i u kojem se ukratko opisuju relevantni dijelovi rada, sa najvažnijim rezultatima i zaključcima.

\section{Upute za oblikovanje teksta}

\subsection{Prva strana}

Prva strana treba sadržavati:

- Naslov rada

- Imena autora, kojima prethodi brojčana oznaka u superskriptu koja ih povezuje sa ustanovom u kojoj rade, u obliku ${ }^{1} / m e$ Prezime.

- Nazive ustanova, kojima prethodi brojčana oznaka u superskriptu koja ih povezuje sa imenom i prezimenom autora, u obliku ${ }^{1}$ Naziv ustanove.

- Sažetak, veličine do 250 riječi, prema uputama kako je gore navedeno. Riječ "Sažetak" je potrebno podebljati.

- Ključne riječi, odvojene zarezom, u obliku Ključne riječi: ključna riječ1, ključna riječ2 Riječi "Ključne riječi” je potrebno podebljati.

- Ispod toga je potrebno dodati i podatke autora za kontakt, koji predstavlja jednog od autora a koji je zadužen za komunikaciju sa uredništvom. Potrebno je navesti ime i prezime, e-mail adresu, kontakt telefon i adresu.

\subsection{Veličina stranice, margine i prored}

Veličina papira treba biti postavljena na A4 $(21 \mathrm{~cm} \times 29,7$ $\mathrm{cm}$ ), sa svim marginama od $2,5 \mathrm{~cm}$. Tekst započinje na slijedećoj strani nakon naslova i sažetka. Prvi odjeljak iza svakog naslova je bez uvlake, a svaki slijedeći odlomak je uvučen za $0,63 \mathrm{~cm}$. Tekst je potrebno pisati jednostrukim proredom, između odjeljaka je potrebno ostaviti jedan red praznog teksta, a prije svakog podnaslova dva reda praznog teksta. of quality writing of scientific and research papers. Other types of papers (theoretical, methodological, review papers) should have adequate format which clearly presents the basic idea and the sequence of conclusions, but the editorial board reserves the right to suggestions and structural corrections. The length of the paper should be from 5 pages up to 20 pages of single-spaced text (one standard page is 1800 characters with single spacing). All papers should have an abstract of up to 250 words, which follows the structure of the text and which briefly describes the relevant parts of the paper, with the most important results and conclusions.

\section{Guidelines for text formatting}

\subsection{Title page}

Title page should contain:

- The title of the paper

- Authors' names preceded by a superscript number denoting their institutional affiliation, e.g. ${ }^{1}$ Name Surname.

- Institution's name preceded by a superscript number denoting the author e.g. ${ }^{1}$ Name of the institution.

- Abstract, up to 250 words, written according to the abovementioned instructions. The word "Abstract" should be written in bold.

- Keywords, divided by commas, as in the example: Keywords: keyword1, keyword2,... "Keywords" should be typed in bold.

- Beneath you should type the corresponding author's/authors' contact details. Type the author's name and surname, email address, phone number and address.

\subsection{Paper size, margins and spacing}

Paper size should be A4 $(21 \mathrm{~cm} \times 29,7 \mathrm{~cm})$, with $2,5 \mathrm{~cm}$ margins on all sides. The text of the article should after the title page. The first paragraph after each heading has no indentation, and each subsequent section should be indented by $0.63 \mathrm{~cm}$. The text should be single-spaced, with an empty line between each paragraph, and two empty lines before each subheading.

\subsection{Font styles, alignment, headings and subheadings}

The use of 12 pt. Times New Roman font is recommended. For the alignment of the abstract and the body of 


\subsection{Vrsta fonta, poravnavanje i označavanje podnaslova}

Preporučeno je korištenje Times New Roman fonta veličine 12 točaka. Poravnavanje sažetka i tijela teksta je potrebno postaviti na obostrano. Naslov rada, imena autora i institucija, podnaslove u tekstu i sadržaj u tabelama je potrebno poravnati na lijevu stranu. Kod brojčanog označavanja podnaslova prve, druge ili niže razine, iza broja je potrebno staviti točku (npr. 4., 4.1., 4.1.1.).

\subsection{Tabele}

Tabele trebaju biti poravnane na lijevu stranu. Svaka tabela treba imati svoj naslov koji započinje sa nazivom Tabela broj tabele. (npr. Tabela 1. Broj pacijenata sa koronarnom bolešću). Tabele se dostavljaju u zasebnoj datoteci, u Microsoft Excel .xls ili .xslx formatu ili Microsoft Word .doc ili .docx formatu.

\subsection{Slike i ilustracije}

Svaka slika i ilustracija treba imati svoj naslov koji započinje sa nazivom Slika broj slike. (npr. Slika 1. Odnos pacijenata tijekom desetogodišnjeg razdoblja...) Slike i ilustracije dostavljaju se u zasebnoj datoteci, u.jpg ili .png formatu.

\subsection{Simboli i jednadžbe}

Prilikom korištenja simbola preporučena je upotreba standardnog Symbol fonta. Za prikaz jednadžbi preporučeno je korištenje Microsoft Equation Editora.

\subsection{Korištenje referenci}

Reference $u$ tekstu se navode Vancouverskim stilom pisanja. Pri tome je potrebno oznaku citiranog rada u tekstu navesti u superskriptu (npr. upute za oblikovanje referenci ${ }^{1}$.

\subsection{Korištenje hrvatskog i engleskog jezika}

Aktualno je omogućeno objavljivanje radova na hrvatskom ili engleskom jeziku. Ukoliko je tekst napisan na hrvatskom jeziku, potrebno je sačiniti sažetak i na engleskom. Ukoliko je tekst napisan na engleskom, sažetak će biti preveden na hrvatski jezik. Navedeni sažetak na engleskom jeziku, potrebno je zajedno sa odgovarajućim naslovom na engleskom jeziku, imenima autora, nazivima institucija, ključnim riječima i adresom autora za kontakt na engleskom jeziku navesti na stranici nakon sažetka i naslova na hrvatskom jeziku. the text the authors should use ,justification“. The title, names of the authors and institutions, subheadings and table content shoud be flush-left. The headings and subheadings should be numbered in the following manner - e.g. 4., 4.1., 4.1.1...

\subsection{Tables}

Tables should be aligned along the left margin. Each table must have a caption or title beginning with Table and a number (e.g. Table 1. Number of patients with coronary disease). Tables are to be sent as a separate file in a Microsoft Excel .xls or .xslx format, or Microsoft Word .doc or .docx format.

\subsection{Images and illustrations}

Photos, graphs, charts or diagrams must have a caption or a title beginning with Figure and a number (e.g. Figure 1.The relationships of patients in the course of a tenyear period...) All images and illustrations are to be sent as a separate file in a .jpg or .png format.

\subsection{Symbols and equations}

The standard Symbol font is recommended for the use of symbols and Microsoft Equation Editora for equations.

\subsection{Using references}

References in the article are cited using the Vancouver citation style. It is necessary to mark the cited paper in the text using a superscript number (e.g. Information on referencing ${ }^{1}$.

\subsection{Using Croatian and English language}

The papers can be published in Croatian or English language. If the article is written in the Croatian language, the abstract has to be written in the English language as well. If the article submitted is written in English, the abstract will be translated into Croatian. Abstracts written in English, together with the corresponding title in English, author names, names of institutions, keywords and author contact information in English, should be written after the abstract and title in the Croatian language.

\section{Paper submission}

Papers are to be sent to the email address jahs@jahs.eu in MS Word.doc or .docx format, and the text must be accompanied by tables and/or illustrations, as indicat- 


\section{Slanje radova}

Radovi se šalju na email adresu jahs@jahs.eu u MS Word .doc ili .docx formatu, a uz tekst je potrebno priložiti tabele i/ili slike, kako je gore navedeno. Prijavljeni radovi ne smiju biti istovremeno objavljeni u nekom drugom časopisu ili poslani na objavljivanje. Svi poslani materijali trebaju biti originalni, a ukoliko se koriste djela drugih autora obavezno je dostaviti odgovarajuće odobrenje vlasnika autorskog prava.

\section{Reference}

Patrias K. Citing medicine: the NLM style guide for authors, editors, and publishers [Internet]. 2. izd. Wendling DL, tehnički urednik. Bethesda (MD): National Library of Medicine (US); 2007 [zadnji puta pristupljeno 07.03.2015]. Dostupno na: http://www.nlm.nih.gov/citingmedicine. ed above. Submitted papers cannot be simultaneously sent for publication or published in another journal. All submitted materials should be original, and if the work of other authors is used the appropriate approval of the copyright holder must be delivered.

\section{References}

Patrias K. Citing medicine: the NLM style guide for authors, editors, and publishers [Internet]. $2^{\text {nd }}$ ed. Wendling DL, (ed.). Bethesda (MD): National Library of Medicine (US); 2007 [cited 2015 Mar 3]. Available from: http:// www.nlm.nih.gov/citingmedicine 

